\title{
GEOHYDROLOGY, WATER QUALITY, AND ESTIMATION OF GROUND-WATER RECHARGE IN SAN FRANCISCO, CALIFORNIA, 1987-92
}

by Steven P. Phillips, Scott N. Hamlin, and Eugene B. Yates

U.S. GEOLOGICAL SURVEY

Water-Resources Investigations Report 93-4019

Prepared in cooperation with the

SAN FRANCISCO WATER DEPARTMENT 


\section{U.S. DEPARTMENT OF THE INTERIOR BRUCE BABBITT, Secretary}

\section{U.S. GEOLOGICAL SURVEY \\ Dallas L. Peck, Director}

Any use of trade, product, or firm names in this publication is for descriptive purposes only and does not imply endorsement by the U.S. Government.

For sale by the Books and Open-File Reports Section U.S. Geological Survey Federal Center, Box 25425

Denver, CO 80225

For additional information write to:

District Chief

U.S. Geological Survey

Federal Building, Room W-2233

2800 Cottage Way

Sacramento, CA 95825 


\section{CONTENTS}

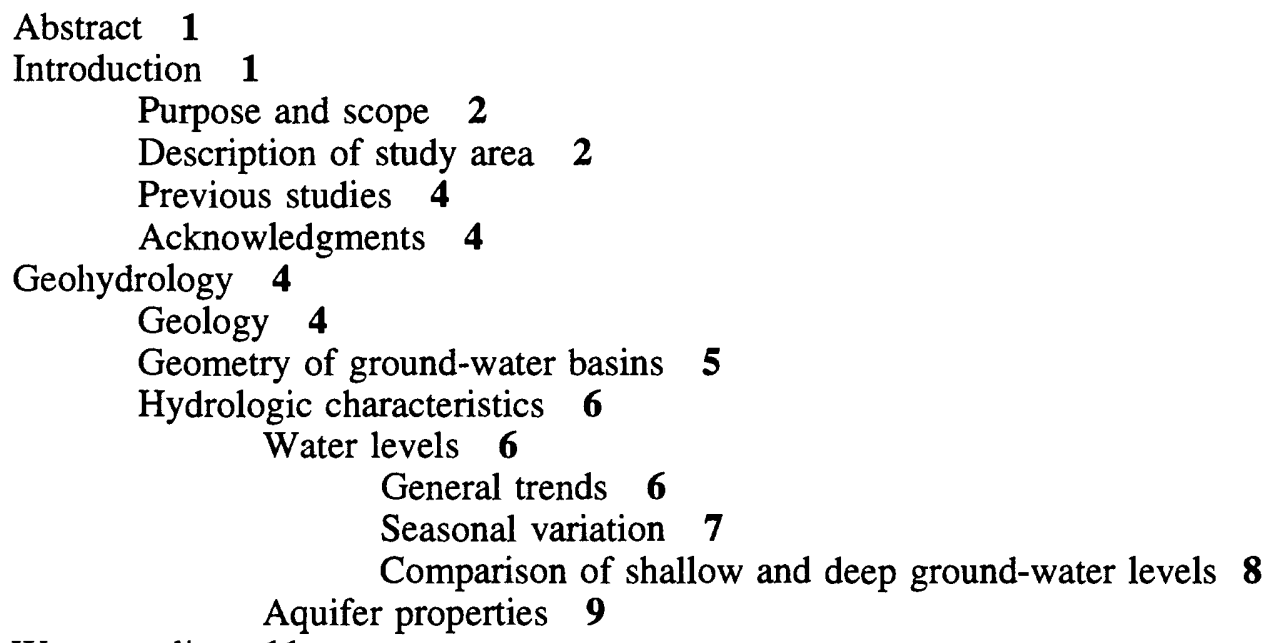




\section{PLATES}

[Plates are in pocket at back of report]

1. Generalized geologic sections through San Francisco, California.

2. Maps of San Francisco and part of San Mateo Counties, California, showing well locations, lateral extent of ground-water basins, altitude of bedrock surface, and rainfall.

3. Map showing thickness of alluvium in the vicinity of San Francisco, California.

\section{FIGURES}

1. Map showing location of study area 3

2-4. Graphs showing:

2. Variation of water levels in selected wells, 1988-92 8

3. Variation of water level in Lake Merced from October 1987 to February 19928

4. Variation of water levels in deep and shallow wells, 1988-92 9

5. Trilinear diagram showing quality of ground water, rain, sewage, and seawater in the

San Francisco area 13

6,7. Graphs showing:

6. Stable-isotope data for ground water, Lake Merced, rainwater, municipal water, and influent sewage in San Francisco and part of San Mateo Counties 16

7. Average monthly temperatures at three weather stations in San Francisco and part of San Mateo Counties, 1959-83 23

8. Map showing land use in San Francisco, April 198927

9-15. Graphs showing:

9. Estimated monthly indoor and outdoor water use in San Francisco, 1987-88 28

10. Relation between actual and potential evapotranspiration based on soil type and soil moisture 32

11. Simulated sewer overflow as a function of rainfall for six storms on the west side of San Francisco in water year $1988 \mathbf{3 4}$

12. Sewer overflow, sewer water pumped to the ocean outfall, and measured sewer flow at the Richmond-Sunset Water Pollution Control Plant, April 1987-September 198834

13. Calculated and measured municipal water delivery in San Francisco, April 1987September $1988 \quad 35$

14. Calculated and measured sewer flow on the west and east sides of San Francisco, April 1987-September 198836

15. Calculated and measured sewer flow for six storms on the west and east sides of San Francisco, water year $1988 \quad 37$

\section{TABLES}

1. Summary of results from aquifer tests in San Francisco $\mathbf{1 0}$

2. Boron, methylene blue active substance, and nitrogen species in ground water in San Francisco and part of San Mateo Counties 14

3. Classification for degree of hardness $\mathbf{1 5}$

4. Stable-isotope ratios for ground water, surface water, and rain water in San Francisco and part of San Mateo Counties 17

5. Tritium concentrations in ground water, surface water, and seawater in San Francisco and part of San Mateo Counties 19

6. Chloride-boron and chloride-bromide ratios for ground water, surface water, sewage, and seawater in San Francisco and part of San Mateo Counties during winter 1988 and spring 1989-90 20

7. Monthly average measured temperatures at San Francisco Airport, water years 1987-88 23 
8. Average annual rainfall at the National Oceanic and Atmospheric Administration gage at the Federal Office Building in San Francisco 23

9. Population density and water use in San Francisco, 197024

10. Estimation of monthly indoor water use as a fraction of monthly total water use in San Francisco 28

11. Estimated and calculated reference evapotranspiration with pan evaporation from Lake Merced 32

12. Rainfall and simulated overflow for six storms on the west side of San Francisco 34

13. Rainfall for six storms in San Francisco during water year 198837

14. Results of sensitivity analysis $\mathbf{3 8}$

15. Areal distribution of calculated ground-water recharge in San Francisco by ground-water basin, water years 1987-88 39

16. Water-level and construction data for wells in San Francisco and part of San Mateo Counties 45

17. Chemical composition of ground and surface water in San Francisco and part of San Mateo Counties

18. Input values for variables used in the calibrated hydrologic routing model that vary by month 56

19. Input values for variables used in the calibrated hydrologic routing model that vary by land-use zone $\mathbf{5 7}$

20. Average annual output from the calibrated hydrologic routing model by land-use zone for the west side of San Francisco, water years 1987-88 60

21. Average annual output from the calibrated hydrologic routing model by land-use zone for the east side of San Francisco, water years 1987-88 62

\section{Conversion Factors, Vertical Datum, Water-Quality Information, and Well-Numbering System}

\section{Conversion Factors}

\begin{tabular}{|c|c|c|}
\hline Multiply & By & To obtain \\
\hline $\begin{array}{r}\text { acre } \\
\text { acre-foot (acre-ft) } \\
\\
\\
\text { acre-foot per month (acre-ft/mo) } \\
\text { acre-foot per year (acre-ft/yr) } \\
\text { foot }(\mathrm{ft}) \\
\text { foot per day }(\mathrm{ft} / \mathrm{d}) \\
\text { foot per year }(\mathrm{ft} / \mathrm{yr}) \\
\text { inch }(\mathrm{in} .) \\
\text { inch per month }(\mathrm{in} / \mathrm{mo}) \\
\text { inch per year }(\mathrm{in} / \mathrm{yr}) \\
\mathrm{mile}(\mathrm{mi}) \\
\text { Million gallons per day }(\mathrm{Mgal} / \mathrm{d}) \\
\text { square mile }\left(\mathrm{mi}{ }^{2}\right)\end{array}$ & $\begin{array}{c}0.4047 \\
4,047 \\
0.3259 \\
1,233 \\
0.001233 \\
1,233 \\
1,233 \\
0.3048 \\
0.3048 \\
0.3048 \\
25.4 \\
25.4 \\
25.4 \\
1.609 \\
3,785 \\
259.0 \\
2.590\end{array}$ & $\begin{array}{l}\text { hectare } \\
\text { square meter } \\
\text { million gallons (Mgal) } \\
\text { cubic meter } \\
\text { cubic hectometer } \\
\text { cubic meter per month } \\
\text { cubic meter per year } \\
\text { meter } \\
\text { meter per day } \\
\text { meter per year } \\
\text { millimeter } \\
\text { millimeter per month } \\
\text { millimeter per year } \\
\text { kilometer } \\
\text { cubic meter per day } \\
\text { hectare } \\
\text { square kilometer }\end{array}$ \\
\hline
\end{tabular}

Temperature is given in degrees Fahrenheit $\left({ }^{\circ} \mathrm{F}\right)$, which can be converted to degrees Celsius $\left({ }^{\circ} \mathrm{C}\right)$ by the following equation:

$$
{ }^{\circ} \mathrm{F}=1.8\left({ }^{\circ} \mathrm{C}\right)+32 \text {. }
$$

\section{Vertical Datum}

Sea level: In this report, "sea level" refers to the National Geodetic Vertical Datum of 1929--a geodetic datum derived from a general adjustment of the first-order level nets of the United States and Canada, formerly called Sea Level Datum of 1929. 


\section{Water-Quality Information}

Chemical concentration is given in milligrams per liter $(\mathrm{mg} / \mathrm{L})$ or micrograms per liter $(\mu \mathrm{g} / \mathrm{L})$. Milligrams per liter is a unit expressing the solute per unit volume (liter) of water. One thousand micrograms per liter is equivalent to 1 milligram per liter. For concentrations less than $7,000 \mathrm{mg} / \mathrm{L}$, the numerical value is the same as for concentrations in parts per million.

\section{Well-Numbering System}

Wells are identified and numbered according to their location in the rectangular system for the subdivision of public lands. The identification consists of the township number, north or south; the range number, east or west; and the section number. Each section is further divided into sixteen 40 -acre tracts lettered consecutively (except I an $\mathrm{O}$ ), beginning with ' $\mathrm{A}$ ' in the northeast corner of the section and progressing in a sinusoidal manner to ' $R$ ' in the southeast corner. Within the 40 -acre tract, wells are sequentially numbered in the order they are inventoried. The final letter refers to the base line and meridian. In California, there are three base lines and meridians; Humboldt $(\mathrm{H})$, Mount Diablo (M), and San Bernardino (S). All wells in the study area are referenced to the Mount Diablo base line and meridian (M). Well numbers consist of 14 characters and follow the format 090N010W34R01M. In this report well numbers are abbreviated and written 9N/10W-34R1M. Wells in the same township and range are referred to only by their section designation, 34R1. The following diagram shows how the number for well $9 \mathrm{~N} / 10 \mathrm{~W}-34 \mathrm{R} 1 \mathrm{M}$ is derived.

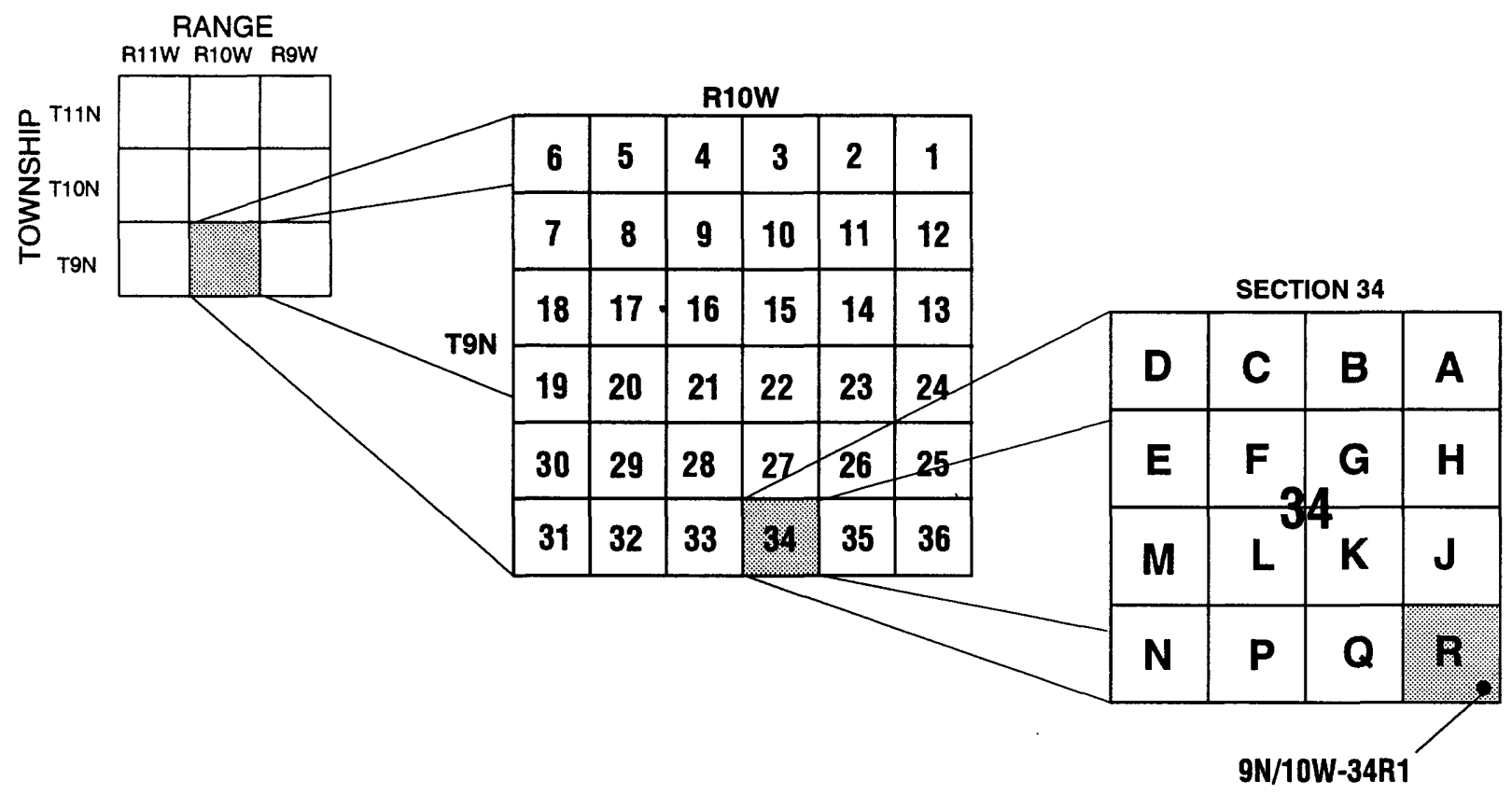




\title{
GEOHYDROLOGY, WATER QUALITY, AND ESTIMATION OF GROUND-WATER RECHARGE IN SAN FRANCISCO,
}

\section{CALIFORNIA, 1987-92}

\author{
by Steven P. Phillips, Scott N. Hamlin, and Eugene B. Yates
}

\begin{abstract}
The city of San Francisco is considering further development of local ground-water resources as a supplemental source of water for potable or nonpotable use. By the year 2010, further water demand is projected to exceed the delivery capacity of the existing supply system, from which San Francisco draws most of its water. The existing system is fed by surfacewater sources; thus, supplies are susceptible to drought conditions and damage to conveyance lines by earthquakes. The primary purpose of this study is to describe local geohydrology and water quality, and to estimate ground-water recharge in the area of the city of San Francisco.
\end{abstract}

Seven ground-water basins were identified in San Francisco on the basis of geologic and geophysical data. Basins on the east side of the city are relatively thin and contain a greater percentage of fine-grained sediments than those on the west side. The relatively small capacity of the basins and greater potential for contamination from sewer sources may limit the potential for ground-water development on the east side. Basins on the west side of the city have a relatively large capacity and low density sewer network. Water-level data indicate that the southern part of the largest basin on the west side of the city (Westside basin) probably cannot accommodate additional ground-water development without adversely affecting water levels and water quality in Lake Merced; however, the remainder of the basin, which is largely undeveloped, could be developed further.
A hydrologic routing model was developed for estimating ground-water recharge throughout San Francisco. The model takes into account climatic factors, land and water use, irrigation, leakage from underground pipes, rainfall runoff, evapotranspiration, and other factors associated with an urban environment. Results indicate that areal recharge rates for water years $1987-88$ for the seven ground-water basins range from 0.32 to 0.78 foot per year. Recharge for the Westside basin was estimated at 0.51 foot per year. Average annual ground-water recharge represents the maximum annual long-term yield of the basin. Attainable yield may be less than the volume of ground-water recharge because interception of all discharge from the basin may not be feasible without inducing seawater intrusion or causing other undesirable effects.

\section{INTRODUCTION}

The city of San Francisco is considering further development of ground water as a local source of water for potable or nonpotable use, and as an emergency supply of potable water. San Francisco currently (1993) imports most of its water, 80 to 90 percent of which comes from the Hetch Hetchy Aqueduct pipeline system. The primary source of this water is nearly $200 \mathrm{mi}$ from San Francisco, in Yosemite National Park. Local sources of water include ground water, which is used primarily for irrigation of parks and golf courses; Lobos Creek, which is diverted for potable use; and Lake Merced, from which water is used for a variety of nonpotable purposes.

The Hetch Hetchy system supplies water to about 2 million people in five counties along the pipeline 
route, and water demands may soon exceed the delivery capacity of the system (Cheryl K. Davis, San Francisco Water Department, written commun., 1988). Current annual average delivery capacity is equivalent to a rate of about $325 \mathrm{Mgal} / \mathrm{d}$ and water use in 1987 averaged $240 \mathrm{Mgal} / \mathrm{d}$ systemwide. Between the years 2000 and 2010, average annual demand is expected to range from 325 to $345 \mathrm{Mgal} / \mathrm{d}$. Greater use of local ground water in San Francisco would reduce the demand and dependency on the Hetch Hetchy system. Also, local ground water could be a major source of emergency drinking-water supply if the Hetch Hetchy pipeline were damaged by an earthquake and temporarily put out of service.

Ground water was a significant source of water supply for San Francisco during the late 1800's and early 1900 's, when water for municipal purposes was obtained from a number of wells and natural springs. Since that time, development of the Hetch Hetchy pipeline system and associated reservoirs has satisfied increasing water demands from the city and other municipalities along the pipeline. The San Francisco Water Department (SFWD) has been operating the system since 1930 . Currently, the major use of spring water is withdrawal of about $2 \mathrm{Mgal} / \mathrm{d}$ from springfed Lobos Creek for the Presidio, which is a military reservation. The major use of ground water in the city is for irrigation at Golden Gate Park, Stern Grove, Fleishhacker Zoo, and several golf courses. A large quantity of ground water is pumped for municipal purposes and irrigation south of the city, between Daly City and San Bruno.

Basic geohydrologic data, water-quality data, and recharge estimates are all essential elements of an assessment of ground-water resources. The city of San Francisco is considering the use of its groundwater resources for supply augmentation and emergency use. This report describes results of a study done by the U.S. Geological Survey in cooperation with the San Francisco Water Department and is an extension of work by Yates and others (1990), who concentrated on the Golden Gate Park and Lake Merced areas of San Francisco.

\section{PURPOSE AND SCOPE}

The primary purpose of this report is to describe local geohydrology and water quality, and to estimate ground-water recharge in the area of the city of San Francisco. Geologic and geophysical data were used to describe the geometry and lithologic characteristics of the ground-water basins. Hydrologic data were used to describe water-level trends, general quality of ground water, and hydraulic properties of aquifer materials that make up the water-bearing part of the ground-water basins. Climate, land and water use, and other data were used to estimate ground-water recharge on an areal basis throughout San Francisco.

Previous studies that contained information pertinent to this study were reviewed. Climatic and other hydrologic data were provided by various public agencies. Additional data collected for this study include geophysical (gravity) data, water levels in Lake Merced and in 56 wells, and water quality of surface and ground water.

\section{DESCRIPTION OF STUDY AREA}

San Francisco is built on the tip of a peninsula on the central California coast. The city and county of San Francisco, which share the same boundary, are bounded on the west by the Pacific Ocean, and on the north and east by the San Francisco Bay (fig. 1). Part of San Mateo County, which is south of San Francisco, is included in this study; however, recharge was not estimated outside of San Francisco.

The total area of San Francisco is about $49 \mathrm{mi}^{2}$. The topography is hilly, with a generally north-south trending topographic divide that reaches a maximum altitude of about $925 \mathrm{ft}$ above sea level. The San Francisco climate is characterized by mild, wet winters and mild dry summers. Westerly winds from the Pacific Ocean and summer fog tend to moderate temperatures; the average daily temperature in Golden Gate Park ranges from $45^{\circ} \mathrm{F}$ in January to $69^{\circ} \mathrm{F}$ in September. Record high and low temperatures are $101^{\circ} \mathrm{F}$ and $27^{\circ} \mathrm{F}$. Annual rainfall is variable throughout the city, but averages about 22.5 in.

The northeastern part of San Francisco is the most developed, with high-rise office and apartment buildings. This part of the city has the highest daytime population because it is the primary destination of most commuters and tourists. The southeastern part of the city is largely industrial and residential, with limited open space. The west side of San Francisco is primarily residential, but contains several large undeveloped areas including Golden Gate Park, the Lake Merced shoreline, and several golf courses near Lake Merced. 


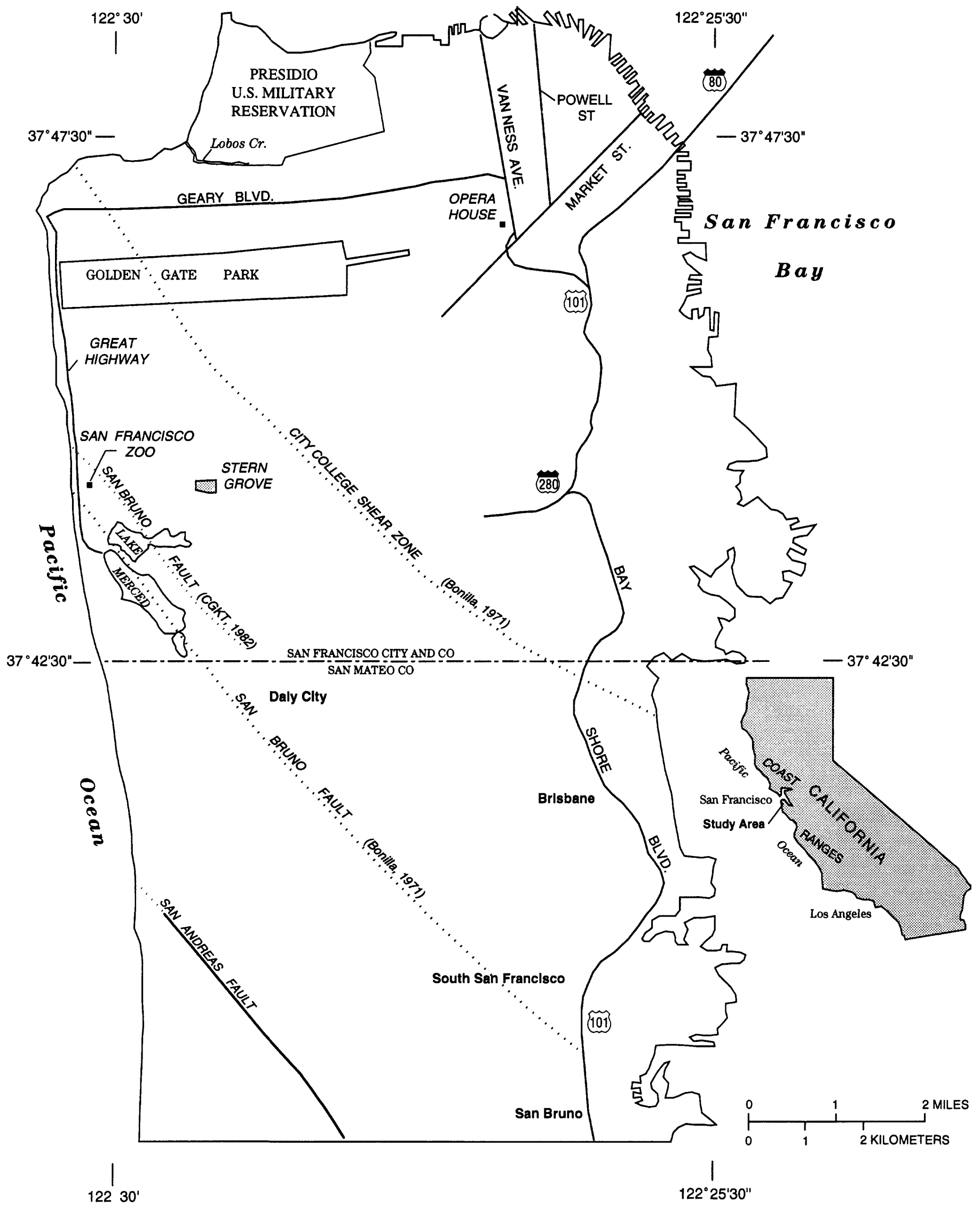

Figure 1. Location of study area. 


\section{PREVIOUS STUDIES}

The first comprehensive evaluation of the groundwater supply in San Francisco was completed by Bartell (1913). Bartell estimated average pumping rates for various districts in the city. At the time, virtually all ground-water development was on the east side because the west side was sparsely populated. Bartell concluded that east-side pumping generally was approaching the limits of safe yield and proposed additional withdrawal on the west side. There have been several studies of the geology of San Francisco and surrounding areas. The most definitive are the geologic maps of the San Francisco North (Schlocker, 1974) and the San Francisco South (Bonilla, 1971) U.S. Geological Survey quadrangles.

Numerous studies by engineering consultants have focused on selected aspects of local geohydrology surrounding construction sites. Many of these studies were associated with the Bayside Facilities plan. The Bayside Facilities, which now are in operation, consist of the Westside Transport System (WSTS) and the Southwest Ocean Outfall (SWOO). The WSTS is a series of high-capacity underground storage tanks along the Great Highway. These tanks are designed to store large volumes of sewer water during storms for later disposal through the SWOO or treatment at the Richmond-Sunset Water Pollution Control Plant (Richmond-Sunset WPCP). Studies for these construction projects contain borehole information, water levels, aquifer properties, and other data.

Yates and others (1990) studied the general geohydrology and water quality of the west side of San Francisco, and studied in detail the Golden Gate Park and Lake Merced areas. Yates and others (1990) includes an extensive discussion of the geology of western San Francisco, water levels, aquifer characteristics, water budgets, and other data and information pertinent to this study.

\section{ACKNOWLEDGMENTS}

Public agencies and corporations that have contributed information and assistance to this study, inclusive of the preliminary report by Yates and others (1990), include the San Francisco Clean Water Program, San Francisco Department of Public Works, Pacific Gas and Electric Company, San Francisco Recreation and Park Department, San Francisco Department of Public Health, San Francisco Fire Department, San Francisco Bureau of Water-Pollution
Control, and Daly City. Private businesses and individuals that contributed information and assistance to the study include Geo/Resource Consultants, Harding-Lawson Associates, Lake Merced Boating and Fishing Company, Olympic Golf Club, San Francisco Golf Club, Bendix Environmental Research, San Francisco State University, Gregory B. Yates, Eve Iverson, Carla M. Reiter, and Chris A. Phanartzis of Hydroconsult Engineers.

\section{GEOHYDROLOGY}

\section{GEOLOGY}

The geologic materials in San Francisco can be divided into two distinct categories: bedrock and unconsolidated sediments. Bedrock in San Francisco consists of consolidated rocks of the Franciscan Complex and the Great Valley Sequence of Late Jurassic and Cretaceous age (Schlocker, 1974). Bedrock crops out in hilly areas and accounts for about 24 percent of the land surface of San Francisco. Plate 1 shows several representative geologic sections of parts of San Francisco.

Overlying bedrock in some areas are unconsolidated sediments that constitute the ground-water basins. On the west side of San Francisco, unconsolidated sediments consist of dune sands and the Colma and Merced Formations of Pleistocene and Pleistocene and Pliocene age, respectively ( $\mathrm{pl} .1 B, 1 C$ ). Generally, the Merced Formation is overlain by the Colma Formation, which in turn is overlain by the dune sands. The Merced Formation consists predominantly of shallow marine and estuarine deposits with thin interbedded muds and peats. Thicker fine-grained layers (10 to $60 \mathrm{ft}$ ) are known to exist (Clifton and Hunter, 1987, p. 260). The Merced Formation dips to the northeast, decreasing from $40^{\circ}$ in the older strata exposed south of Daly City to 10 or $15^{\circ}$ in the youngest strata exposed near Lake Merced (Bonilla, 1971). Tilted fine-grained strata might impede horizontal flow of ground water.

The Colma Formation, which overlies the Merced Formation, probably consists largely of reworked material from the Merced Formation (Schlocker, 1974). The Colma Formation consists of nearly flatlying fine-grained sand, silty sand, and occasional beds of clay as much as $5 \mathrm{ft}$ thick. Dune sands overly the Colma Formation over most of the west side of San Francisco north of Lake Merced and range in thickness from 0 to $150 \mathrm{ft}$ (Schlocker, 1974). The dune sands consist of well-sorted fine- to medium-grained sand. 
On the north and east sides of San Francisco, the unconsolidated sediments consist of dune sand, the Colma Formation, bay mud and clay, artificial fill, and other relatively fine-grained surficial deposits (pl. $1 D-1 F)$. The unconsolidated sediments on the east side generally are more fine grained than those on the west side. The artificial fill reaches a maximum thickness of about $60 \mathrm{ft}$, and is composed primarily of dune sand, but also contains silt, clay, and various natural and manmade debris (Schlocker, 1974). Bay mud and clay deposits, which reach a maximum thickness of about $140 \mathrm{ft}(\mathrm{pl} .1 D-1 F)$, are described as a plastic gray silty clay (Schlocker, 1974).

Significant structural features include a series of northwest-trending faults, including the San Andreas Fault, the San Bruno Fault, and the City College Shear Zone. The San Andreas Fault is 2 to $3 \mathrm{mi}$ offshore west of San Francisco. It is not known whether the fault has an effect on the hydraulic connection between the ground-water basin and the Pacific Ocean. The San Bruno Fault passes through the Lake Merced area, although the age, exact location, and offset are unknown. Also, it is unknown whether the fault acts as a hydraulic barrier or conduit, but water levels near Lake Merced do not indicate the presence of a barrier. The City College Shear Zone trends northwestward from Bayshore, and cuts through the western part of Golden Gate Park. Water levels in Golden Gate Park do not indicate that the fault acts as a hydraulic barrier. Yates and others (1990) provide a more extensive discussion of these faults.

The structure of the subterranean bedrock surface has been mapped in various parts of San Francisco by previous investigators (Bonilla, 1964; 1971; Carlson and McCulloch, 1970; Schlocker, 1974). A comprehensive map of bedrock altitude in San Francisco and northern San Mateo County was compiled using data from the aforementioned investigations, more recent borehole data, and geophysical data collected for this investigation. Borehole data were extracted from water well driller's logs provided by the California Department of Water Resources, test boring logs were provided by the California Department of Transportation (CALTRANS), and from private consultants (Harding-Lawson Associates, 1976b; Dames and Moore, 1979; Caldwell-Gonzalez-Kennedy-Tudor, 1982). The overlapping existing maps and borehole data provided reasonably good coverage of the eastern and northern parts of San Francisco, but data were sparse on the west side where the bedrock surface is relatively deep. Yates and others (1990) pointed out that the depth and shape of the Westside basin is highly speculative because of minimal borehole data and conflicting geophysical evidence.

A gravity survey was done for the purpose of estimating the shape of the bedrock surface on the west side of San Francisco and San Mateo Counties (Roberts, 1991). Relative changes in gravity measured on an areal grid indicate changes in density of subsurface materials. Consolidated materials (bedrock) are more dense than unconsolidated materials (alluvium); thus, relatively small gravity measurements indicate relatively thick alluvium. More than 700 gravity measurements were made and the gravity data were calibrated to bedrock altitude using data from about 200 boreholes.

Plate $2 B$ is the compiled map of bedrock altitude representing the work of previous investigators, new borehole data, and new geophysical data. The bedrock surface is complex, ranging in altitude from the land surface to more than $3,500 \mathrm{ft}$ below sea level. The bedrock altitude is relatively high on the east side of San Francisco, with a minimum altitude of about $275 \mathrm{ft}$ below sea level. On the west side, bedrock altitude generally decreases southward, and reaches a minimum altitude of about 3,500 ft below sea level along the coast about $1.5 \mathrm{mi}$ south of Lake Merced in San Mateo County. The minimum bedrock altitude in San Francisco County is about 2,500 ft below sea level, shoreward of Lake Merced.

\section{GEOMETRY OF GROUND-WATER BASINS}

A ground-water basin is defined here as a continuous body of unconsolidated sediments and the surrounding surface drainage area. Seven major groundwater basins were identified in San Francisco (pl. 2A) on the basis of geologic and geophysical data. All basins are open to the Pacific Ocean or San Francisco Bay. The landward parts of the ground-water basins generally are bounded horizontally and vertically by bedrock, which is assumed to be relatively impermeable compared with unconsolidated alluvium. Ground-water flow may occur between basins where the bedrock ridge that constitutes the boundary is subterranean. The north-south topographic and bedrock high defined by the Coast Ranges generally forms an east-west hydrologic boundary through San Francisco.

The western part of San Francisco is divided into the Westside and Lobos basins on the basis of a northwest-trending bedrock ridge through the north- 
eastern part of Golden Gate Park (pl. 2A). The bedrock ridge has several small surface expressions, and bedrock altitude data indicate that the ridge is continuous, though subterranean. Some degree of hydraulic connection is possible between the two basins where the ridge is not exposed at the land surface, but the degree of connection probably is minimal. The Westside basin, which is the largest ground-water basin in San Francisco, is not contained fully in San Francisco, as the Merced Formation extends as far south as San Bruno. The areal extent of the Westside basin in San Francisco is about 9,451 acres. The Lobos basin to the north of the Westside basin includes about 2,379 acres.

The eastern part of San Francisco is divided into five basins on the basis of bedrock ridges that virtually are exposed entirely at the land surface. The Marina basin is the northernmost and includes about 2,224 acres. The Downtown basin, to the south of Marina basin, is the largest of the eastern basins at 7,512 acres. Continuing from north to south are the Islais Valley, South, and Visitacion Valley basins, which include about 5,000, 2,130, and 800 acres in San Francisco County, respectively. Basin names used in this report other than the formal designations Islais Valley and Visitacion Valley from the California Department of Water Resources (1975a) are informal designations.

Plate 3 is a map of alluvial thickness generated from the bedrock altitude map (pl. $2 B$ ) and digital topographic data. The thickness of unconsolidated alluvial deposits in a ground-water basin is a primary factor that controls the potential for ground-water development. Thin ground-water basins have a relatively low storage capacity and provide a minimal buffer zone between the screens of production wells and shallow ground water that is susceptible to surface contamination. Plate 3 shows that the alluvium generally is thinner on the east side of San Francisco, with a maximum thickness of less than $300 \mathrm{ft}$. Maximum alluvial thickness on the west side of San Francisco is about 2,500 ft, and thickness is as much as 3,500 $\mathrm{ft}$ in San Mateo County. The relatively thin ground-water basins on the east side do not preclude ground-water development in this area. In the early 1900 's, about 6,900 acre-ft/yr was withdrawn from east-side ground-water basins. This level of development was not without problems because drawdown was significant in some areas, and high chloride concentrations in at least two wells may indicate seawater intrusion (Bartell, 1913).

\section{HYDROLOGIC CHARACTERISTICS}

\section{WATER LEVELS}

The water level measured in a well indicates the hydraulic head at the depth of the well screen. Hydraulic head is a measure of the potential energy of ground water at a point in the ground-water basin. It is expressed as an altitude with respect to sea level in this report. Water levels were measured periodically in 56 wells for this study, 54 of which are shown on plate $2 A$. The two wells not shown are at the San Francisco International Airport, which is south of the study area on the shore of San Francisco Bay. Although various trends in water levels were identified, a water-level contour map was not drawn because of the sparsity and uneven areal distribution of well data, and the extreme variability of the topography and the bedrock surface. Water-level data for all wells measured are given in table 16 (at back of report).

General trends.--Hydraulic gradients generally follow topographic slopes in the San Francisco area, except where affected by ground-water pumping. Water levels are lowest along the shore and in areas of pumping depressions, such as around the southern part of Lake Merced (Yates and others, 1990). Pumping from the deep part of the aquifer system also produces a downward hydraulic gradient in this area, from the shallow to the deep part of the aquifer system.

Ground-water levels on the east side of the city generally are closer to the land surface than those on the west side. Ground-water basins on the east side are thinner and smaller in volume than those on the west side. Studies of sewer flow indicate that infiltration of ground water predominantly occurs on the east side, where the water table commonly is above the sewer lines (San Francisco Department of Public Works, 1974a). Many underground structures in this area, such as the Powell Street Bay Area Rapid Transit (BART) station and the basement at the Opera House, require sump pumps to remove infiltrating ground water. Historically, ground-water pumping coupled with small storage resulted in water levels that declined below sea level in the downtown area (Bartell, 1913). The water table on the west side generally is below the level of sewer lines, which results in exfiltration of sewage to the ground-water system where leaks are present (San Francisco Department of Public Works, 1974b). 
During the course of this study (1987-92), all wells showed declining water levels. This effect is primarily a result of reduced recharge during the concurrent drought. Water levels in wells near the landward edges of ground-water basins tend to have linear declines, such as at the Herz Playground (fig. 2A). Between 1989 and 1992, the water level in this well declined nearly $10 \mathrm{ft}$. Declines in this and other wells indicate that discharge from the ground-water basins exceeds recharge. A resumption of average rainfall could reverse this trend because water previously lost from storage is replenished.

Seasonal varlation.--Seasonal variations in ground-water levels are affected by changes in recharge and pumpage. Generally, highs in the water table may occur in late winter at the end of the rainy season. Lows usually occur in the autumn at the end of the irrigation season and before winter rains.

Many wells in the San Francisco area are used for irrigation and other nonpotable purposes. The variations in the water table caused by pumping tend to mask the effects of seasonal recharge. Most wells in areas not affected by pumping showed declining water levels without significant evidence of recovery due to seasonal recharge. However, the well at Brussels Street (fig. $2 B$ ) did show a small water-level rise during the winters of 1989 and 1990. Aside from the winter recovery, water levels generally declined during this period. This well is near the center of the ground-water basin in contrast to the well at the Herz Playground at the edge of the basin that showed a decline of about $10 \mathrm{ft}$ during the same period.

Ground-water pumping has produced the most significant changes in water levels. Dewatering of structures below the water table in the downtown area (basements and BART tunnel) and irrigation on the west side of the city (Golden Gate Park and Lake Merced area) account for the largest withdrawals of ground water in San Francisco. Dewatering generally is continuous throughout the year and produces a fairly constant, localized drawdown in the water table. This effect may be seen in the hydrographs for wells at the International Center and the Phelan Building in the downtown area (fig. $2 C$ ). The two wells are about $1 \mathrm{mi}$ apart and $100 \mathrm{ft}$ deep. The altitude of the land surface at the International Center is about $10 \mathrm{ft}$ higher than at the Phelan Building. Ground-water pumping is insignificant near the International Center and water-level altitudes are about $30 \mathrm{ft}$ above sea level. In contrast, the well at the Phelan Building is near the Powell Street BART station, which pumps large quantities of ground water for dewatering purposes. Water levels at this well are about $5 \mathrm{ft}$ below sea level, or $35 \mathrm{ft}$ lower than those at the International Center. Ground-water levels that decline below sea level in areas near the shore may induce seawater intrusion.

In contrast to the fairly constant drawdown produced by dewatering, ground-water pumping for irrigation produces a seasonal variation in water levels. This phenomenon is observed in the irrigation well at Holy Cross Cemetery, where water levels are about $15 \mathrm{ft}$ lower during the irrigation season (fig. $2 D$ ). Ground-water pumping has resulted in water-level altitudes greater than $100 \mathrm{ft}$ below sea level in some areas. Water-level altitudes are relatively low beneath cemeteries, parks, golf courses, and other areas where ground water is pumped for irrigation. Water levels. are relatively low near the southwestern part of the city as a result of pumping for irrigation in the city, and pumping for potable use in Daly City. Water levels declined more than $150 \mathrm{ft}$ below sea level (Applied Consultants, 1991, fig. 11) in some areas as a result of pumping for potable use in Daly City.

Water levels in Lake Merced show the effects of seasonal recharge and ground-water and surface-water pumping (fig. 3). The San Francisco and Olympic Golf Clubs adjacent to the south arm of Lake Merced pump ground water from the deep part of the aquifer system for irrigation as do Daly City and the Lake Merced Country Club to the south. Pumping drawdowns in the deep aquifer have induced downward flow from the shallow aquifer in this area; consequently, water levels in the shallow part of the aquifer system also declined. Lake Merced virtually is an exposed part of the water table and has been declining for more than 10 years (Yates and others, 1990). Maximum yearly water levels reflect recharge and runoff from winter rains. Subsequent natural and pumping-induced discharge cause the lake level to decline to a minimum value in the autumn before recharge from subsequent rainfall. Yearly declines measured among minimum values were $1.4 \mathrm{ft}$ for $1987-88,1.2 \mathrm{ft}$ for $1988-89,2.5 \mathrm{ft}$ for $1989-90$, and $0.3 \mathrm{ft}$ for 1990-91 (fig. 3). The smaller decline for 1990-91 may reflect changes in pumping and weather. Direct pumping from the lake to irrigate the Harding Park Golf Course was discontinued in late 1990. Additionally, the San Francisco and Olympic Golf Clubs reportedly pumped less ground water as a result of an unusually cool and foggy summer. 

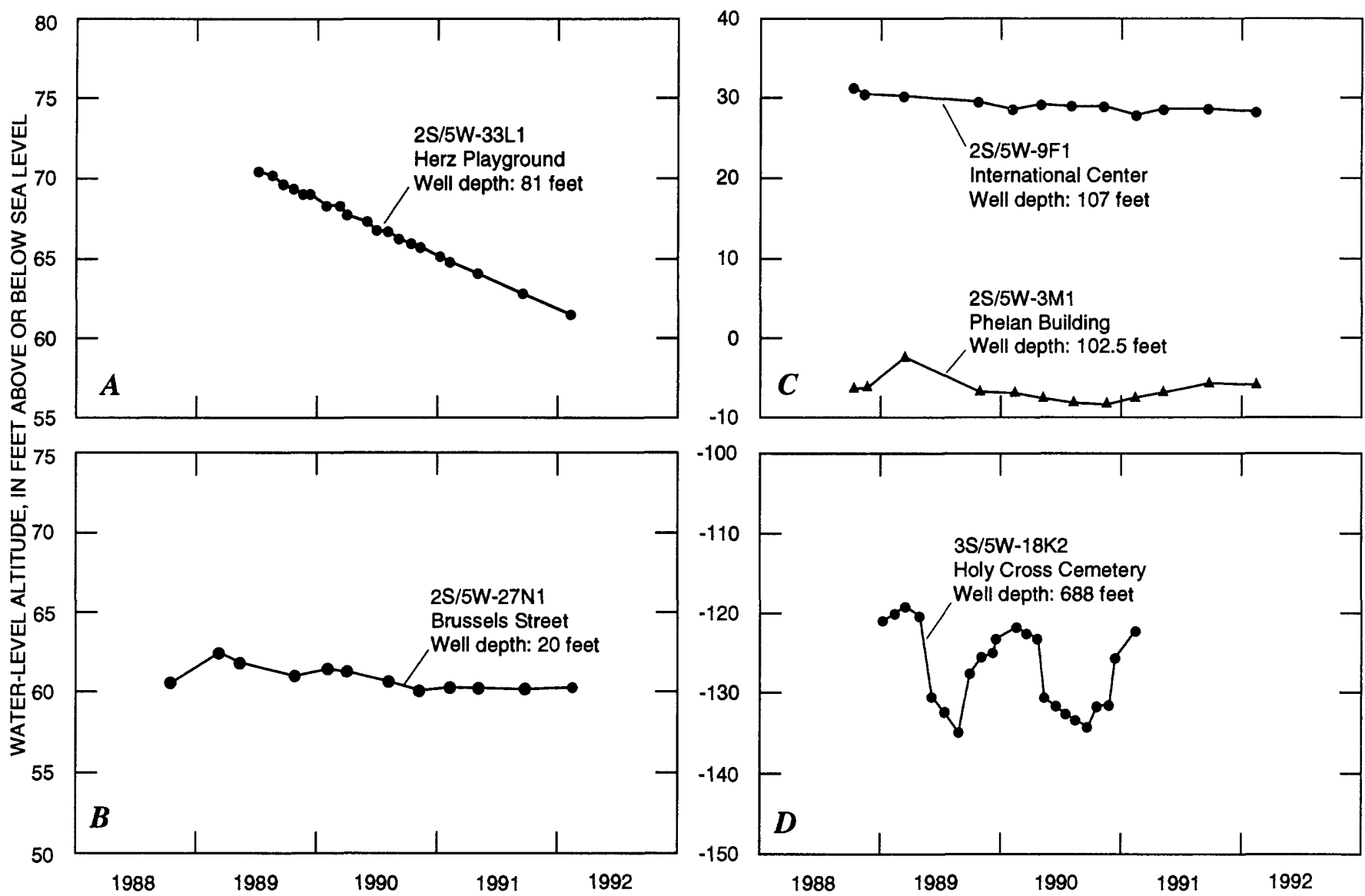

Figure 2. Variation of water levels in selected wells, 1988-92. Well depths are in feet below land surface.

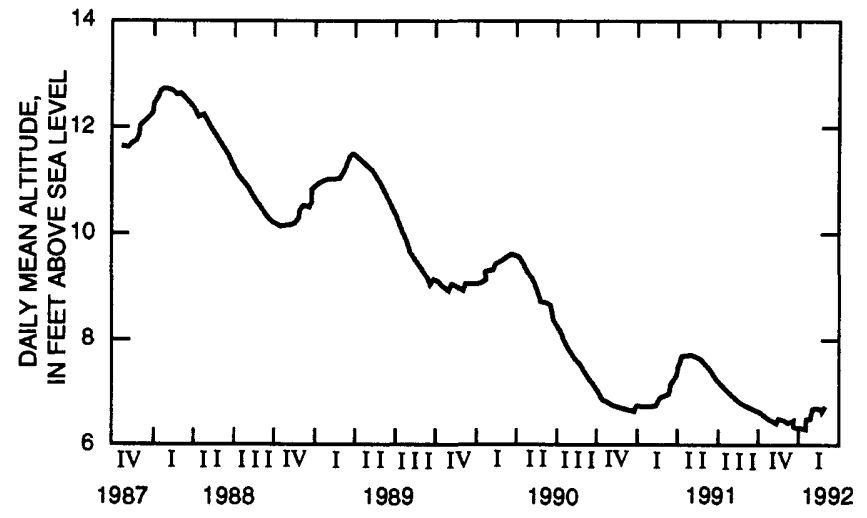

enough, approximate vertical gradients can be estimated. Deep pumping around the south arm of Lake Merced and in Daly City to the south has produced a localized downward hydraulic gradient. Water levels in wells decrease with increasing well depth. This effect is observed in shallow and deep wells at the Olympic Golf Club (fig. 4A). The well at Harding Park is screened in shallow and deep parts of the aquifer and is near the north area of Lake Merced, away from major pumping effects. It shows the highest water levels, about $10 \mathrm{ft}$ above sea level (fig. $4 A$ ). Water levels in the shallow well at the Olympic Golf Club declined from a few feet above to about 1 foot below sea level between 1989-92. Water levels in the deep well at the Olympic Golf Club ranged between about 30 and $50 \mathrm{ft}$ below sea level. Water levels in wells at the San Francisco Golf Club show a similar downward hydraulic gradient (fig. 4B). Water levels in the shallow well at the San Francisco Golf Club declined from a few feet above to about 1 foot below sea level between 1989-92. Water levels in the east well ( $324 \mathrm{ft}$ deep) ranged between 30 and $40 \mathrm{ft}$ below sea level. Water levels in the deeper west well (540 $\mathrm{ft}$ ) ranged between 50 anả $80 \mathrm{ft}$ below sea level. 

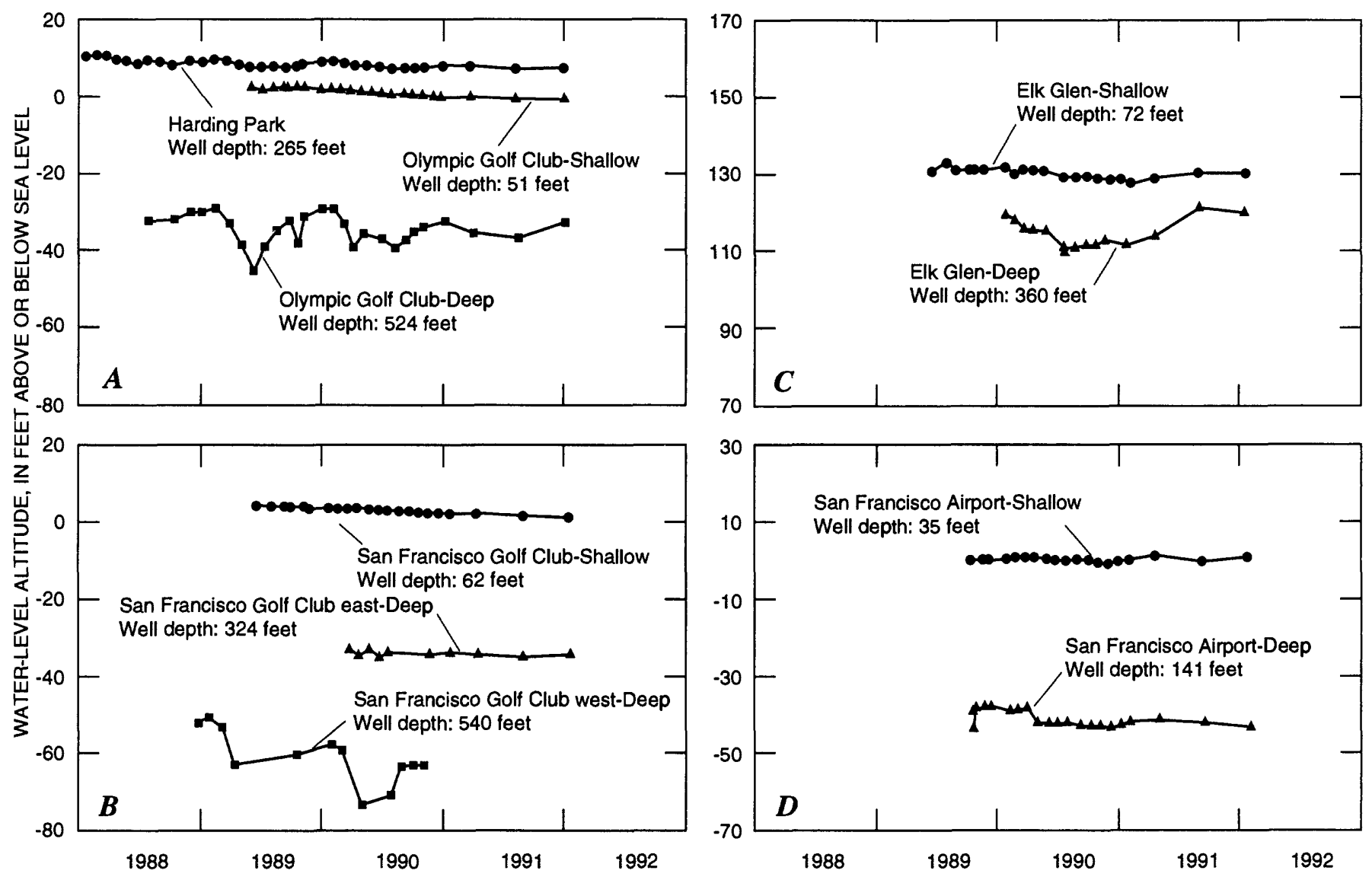

Figure 4. Variation of water levels in deep and shallow wells, 1988-92. Well depths are in feet below land surface.

A significant downward hydraulic gradient also was measured in wells near Elk Glen Lake in Golden Gate Park (fig. 4C). Water levels in the shallow well ranged from about 125 to $130 \mathrm{ft}$ above sea level. Water levels in the deep pumped well ranged between 110 and $120 \mathrm{ft}$ above sea level. Hydrographs for both wells show similar trends, although attenuated in the shallow well. A minimum water level occurs during late 1990 to early 1991 . The subsequent rise in water levels represents a recovery period during which the pump was shut down for repairs. The pump was put back into operation in late 1991, and water levels subsequently began to decline.

The downward hydraulic gradient observed at the San Francisco Airport (fig. $4 D$ ) probably results from pumping near San Bruno. Water levels in the shallow well are slightly below sea level; whereas water levels in the deep well are between 35 and $45 \mathrm{ft}$ below sea level. A thick clay layer separates the shallow brackish aquifer from the deep freshwater aquifer. However, the large downward gradient increases the possibility of saltwater contamination in the deep aquifer from the overlying brackish water.

\section{AQUIFER PROPERTIES}

An aquifer is defined here as a continuous body of unconsolidated sediments in a ground-water basin. Hydraulic conductivity and storage are aquifer properties that govern the response of a ground-water system to hydrologic stresses. Coarse-grained materials such as sand have a greater hydraulic conductivity than fine-grained materials such as clay; therefore, horizontal ground-water flow will be greater in the coarse-grained part of horizontally layered deposits. Table 1 shows the results of aquifer tests done in San Francisco to determine horizontal hydraulic conductivity. Some of these tests also yielded an estimate of the storage coefficient. Most of these aquifer tests were done on the west side of San Francisco. Although data for the east side are sparse, the sands are lithologically similar to those on the west side (Schlocker, 1974). However, the effective horizontal and vertical hydraulic conductivity of the east-side aquifers should be considerably lower than those for the west side because of the greater proportion of fine-grained sediments on the east side. 
Table 1. Summary of results from aquifer tests in San Francisco

[Well name or location: D, deep. WPCP, Water Pollution Control Plant. Depth of well in feet below land surface. $\mathrm{ft}$, foot; $\mathrm{ft} / \mathrm{d}$, foot per day. --, no data]

\begin{tabular}{|c|c|c|c|c|c|}
\hline $\begin{array}{c}\text { Map } \\
\text { No. } \\
\text { (pl. 2A) }\end{array}$ & $\begin{array}{l}\text { Well name or } \\
\text { sample source }\end{array}$ & $\begin{array}{l}\text { Depth } \\
\text { of well }\end{array}$ & $\begin{array}{l}\text { Thickness of } \\
\text { pumped } \\
\text { interval } \\
(\mathrm{ft})\end{array}$ & $\begin{array}{c}\text { Horizontal } \\
\text { hydraulic } \\
\text { conductivity } \\
(\mathrm{ft} / \mathrm{d})\end{array}$ & $\begin{array}{c}\text { Storage } \\
\text { coefficient } \\
\text { (dimensionless) }\end{array}$ \\
\hline 5 & $\begin{array}{l}\text { Alvord Park and } \\
\quad \text { Recreation No. } 2^{1}\end{array}$ & 249 & 65 & 18 & -- \\
\hline 5 & $\begin{array}{l}\text { Alvord Park and } \\
\quad \text { Recreation No. } 2^{2}\end{array}$ & 249 & 65 & 22 & 0.00056 \\
\hline 16 & Windmill Northwest ${ }^{1}$ & 281 & 280 & 14 & -- \\
\hline 17 & Elk Glen-D ${ }^{1}$ & 360 & 180 & 16 & -- \\
\hline 20 & Arboretum $4^{1}$ & 250 & 230 & 5 & -- \\
\hline 21 & Arboretum $5^{1}$ & 250 & 230 & 13 & -- \\
\hline 39 & Stern Monument ${ }^{3}$ & 269 & 210 & 21 & .0082 \\
\hline 44 & Zoo $03^{1}$ & 220 & 185 & 24 & -- \\
\hline 45 & Zoo $04^{1}$ & 220 & 180 & 31 & -- \\
\hline 61 & Fleishhacker Pool ${ }^{4}$ & 80 & 54 & 28 & .01 \\
\hline 62 & Oceanside WPCP5 & 100 & 80 & 17 & .32 \\
\hline 62 & Oceanside WPCP & - & 300 & 8 & .00024 \\
\hline 64 & Southeast WPCP & -- & 150 & 13 & .00084 \\
\hline 65 & Westside Transport System ${ }^{8}$ & 120 & 98 & 10 & -- \\
\hline
\end{tabular}

\footnotetext{
'Yates and others (1990)

${ }^{2}$ Woodward-Clyde Consultants (1985)

${ }^{3}$ Caldwell-Gonzalez-Kennedy-Tudor (1982)

${ }^{4}$ Modified from Harding-Lawson Associates (1977)

${ }^{5}$ Woodward-Clyde Consultants (1980)

${ }^{6} \mathrm{CH} 2 \mathrm{M}$-Hill (1989)

${ }^{7}$ Coast Geo-Constructors, Inc. (1987)

${ }^{8}$ Modified from Harding-Lawson Associates (1976a)
}

The average horizontal hydraulic conductivity in table 1 is about $17 \mathrm{ft} / \mathrm{d}$, which is within the range from 2 to $200 \mathrm{ft} / \mathrm{d}$ reported for silty sands to sands (Davis, 1969; Freeze and Cherry, 1979, p. 29; Heath, 1987, p. 13). The storage coefficients in table 1 range from 0.00024 , which indicates confined or semiconfined conditions, to 0.32 , which indicates unconfined conditions. The larger values of storage coefficient coincide with the shallowest wells tested.

Vertical hydraulic conductivity is more difficult to determine than horizontal hydraulic conductivity, and only two estimates were found. Aquifer-test data were used to estimate a vertical hydraulic conductivity of $0.0018 \mathrm{ft} / \mathrm{d}$ for a 45 -foot thick clay layer underlying the Oceanside WPCP (CH2M-Hill, 1989). This value is considerably lower than the average horizontal hydraulic conductivity $(17 \mathrm{ft} / \mathrm{d})$ and indicates that the clay layer may act as a confining unit. The relatively low storage coefficient derived for the zone below the clay at the same site $(0.00024)$ also indicates confined conditions. Woodward-Clyde Consultants (1977) tested eight core samples in the laboratory to estimate vertical hydraulic conductivity. The core samples were collected from depths ranging from 89 to $262 \mathrm{ft}$. One of the core samples was classified as a clay, and the measured vertical hydraulic conductivity was $0.0025 \mathrm{ft} / \mathrm{d}$. Seven of the eight core samples were classified as poorly sorted or silty sands, and the median vertical hydraulic conductivity of these samples was $0.28 \mathrm{ft} / \mathrm{d}$ with a range of 0.057 to $5.1 \mathrm{ft} / \mathrm{d}$. A comparison of the highest horizontal hydraulic conductivity $(31 \mathrm{ft} / \mathrm{d})$ with the highest vertical hydraulic conductivity $(5.1 \mathrm{ft} / \mathrm{d})$, which can be assumed to occur in the same materials, indicates that the minimum horizontal-to-vertical anisotropy may be about $6: 1$. The range of horizontal ( 5 to 31 $\mathrm{ft} / \mathrm{d})$ and vertical $(0.0018$ to $5.1 \mathrm{ft} / \mathrm{d})$ hydraulic conductivities indicates that the coarse-grained deposits that control horizontal flow are relatively 
continuous, and that fine-grained deposits that control vertical flow are relatively discontinuous. Storage coefficients (table 1) indicate unconfined conditions at depths less than $100 \mathrm{ft}(0.01$ to 0.32$)$ and confined or semiconfined conditions $(0.00024$ to 0.0082$)$ at depths greater than $100 \mathrm{ft}$.

\section{WATER QUALITY}

\section{SAMPLE COLLECTION AND ANALYSIS}

Samples of ground water, surface water, and municipal water were collected in the San Francisco area to help determine the effects of urban land use on ground-water quality. Production wells were sampled either from a petcock at the well head or from the discharge pipe. Monitoring wells were sampled using a piston-type, submersible pump to prevent aeration of the water during pumping. A peristaltic pump with plastic tubing was used to collect samples from springs feeding Lobos Creek, and water from Lake Merced was collected using a van Doran sampler. Municipal water was sampled from the water main at the Lake Merced pump station.

Prior to collection of the samples, wells were purged of stagnant water in the casing as determined by stabilization of the electrical conductance of the discharged water. Treatment and preservation of the water samples followed procedures outlined by Wood (1976). Temperature, $\mathrm{pH}$, specific conductance, and alkalinity were measured in the field according to techniques outlined by Marc Sylvester (U.S. Geological Survey, written commun., 1990). Tritium samples were collected in 1-liter glass bottles to prevent contamination with atmospheric tritium. Water samples for stable-isotope analysis were collected in glass bottles fitted with polyseal caps to prevent evaporation.

Isotopes of some elements in a water body may be useful in determining the history and sources of ground-water recharge. The isotopes used most extensively in hydrologic studies are hydrogen-2 $\left({ }^{2} \mathrm{H}\right.$, deuterium) and oxygen-18 $\left({ }^{18} \mathrm{O}\right)(\mathrm{Hem}, 1985, \mathrm{p} .162)$. These heavy isotopes occur naturally in average proportions of 0.01 percent hydrogen and 0.2 percent oxygen in water molecules. Mass spectrometry analysis allows rapid and accurate measurement of ratios of the main isotopes that constitute the water molecule, ${ }^{18} \mathrm{O} /{ }^{16} \mathrm{O}$ and ${ }^{2} \mathrm{H} /{ }^{1} \mathrm{H}$. The isotope ratios are expressed in delta units $(\delta)$, which are parts per thousand (per mil) differences relative to an arbitrary standard known as standard mean ocean water (Freeze and
Cherry, 1979). Concentrations of ${ }^{2} \mathrm{H}$ and ${ }^{18} \mathrm{O}$ are, in general, correlated linearly. Graphic representation of this relation is known as the meteoric water line. The departure and distribution of ${ }^{18} \mathrm{O}$ and ${ }^{2} \mathrm{H}$ concentrations related to this line can be used to distinguish sources of ground-water recharge.

During the process of evaporation, water molecules containing the heavy isotopes tend to become concentrated in the residual water, while molecules containing the lighter isotopes become concentrated in the water vapor, rain, and snow. Hence, ocean water is enriched with respect to the heavy isotopes. Because water vapor moves inland, the process of condensation and precipitation is repeated many times. The vapor progressively becomes more depleted of heavy isotopes. This characteristic was observed in the local municipal water, which consists largely of water from Hetch Hetchy Reservoir in the Sierra Nevada, about 200 mi east of San Francisco.

The equation describing the meteoric water line varies with geographic location. The equation used for precipitation in San Francisco is:

$$
\delta^{2} \mathrm{H}=8 \times \delta^{18} \mathrm{O}+10.89 .
$$

This equation was derived from data collected at Santa Maria, California (International Atomic Energy Agency, 1981).

\section{FACTORS AFFECTING WATER QUALITY}

Concentrations of dissolved constituents in local ground water are affected by irrigation-return flow (fertilizers), leakage from sewers, saltwater contamination, and geologic sources. Recharge from rain water and municipal water chiefly affects the isotopic composition of ground water and is not a major source of most dissolved constituents. The chemical signatures of these sources of solutes commonly are similar. For example, sewage and fertilizers are major sources of nitrate in ground water. Likewise, chloride may be derived from sewage and saltwater. Concentrations of these two common ions may limit potable usage of ground water. The relative effects of these sources on ground-water quality are evaluated using graphical methods, ion ratios, isotopic analysis, and trace-element associations.

The three main nutrients in fertilizers are nitrogen, phosphorus, and potassium. Nitrogen is the most mobile in ground water and is a common contam- 
inant. Fertilizers also may add sulfate to ground water. In the San Francisco area, the largest quantities of fertilizers are applied to residential landscaping and golf courses. Residential use probably accounts for the greatest contribution of fertilizer chemicals to ground water because of the larger total land area than that for golf courses. Additionally, homeowners are more likely to apply fertilizers in excess of plant needs than the gardeners at golf courses.

Leakage from sewers may introduce dissolved constituents to ground water that are similar to those from fertilizers (nutrients, sulfate). In addition, sewage generally contains high concentrations of chloride due to widespread use of salt in human activities and the infiltration of saltwater into sewer pipes on the east side of San Francisco. The average concentration of chloride in sewage flowing to the Richmond-Sunset WPCP on the west side of the city is $139 \mathrm{mg} / \mathrm{L}$, compared with $793 \mathrm{mg} / \mathrm{L}$ in sewage flowing to the Southeast WPCP servicing the southeast side of the city (Jon Loiacano, San Francisco Clean Water Program, written commun., 1991). Infiltration of bay water occurs at some sewer outfalls on the east side in the tidal zone. Gates and valves intended to prevent bay-water infiltration occasionally malfunction and allow saltwater to enter the sewer system. On the west side of the city, the Steinhart Aquarium in Golden Gate Park discharges wastewater from saltwater aquariums to the sewer system. The difference in average sewer-water composition between the east and west sides of the city is shown in figure 5. Water from both sewage systems shows the effects of saltwater input; however, the chemically conservative anions indicate that the composition of east-side sewage is much closer to seawater composition than west-side sewage. Additionally, salts from ocean water also may be introduced directly to ground water by seawater intrusion, or indirectly by washdown and infiltration of salt spray.

Many dissolved constituents in natural ground water are derived, at least in part, from interaction with minerals composing the aquifer. Concentrations of ionic species, such as fluoride, may be controlled by equilibrium with a mineral, such as fluorite. Additionally, cation-exchange reactions with clay minerals often control the composition of cations in ground water. Some rocks serve as sources of the chloride and sulfate anions to ground water. However, the bicarbonate anion present in most water is derived in large part from carbon dioxide in the atmosphere (Hem, 1985).
VARIATION OF WATER-QUALITY CHARACTERISTICS

\section{GENERAL CONDITIONS}

The quality of ground water in western San Francisco was described by Yates and others (1990). The general characteristics of ground water are similar throughout the San Francisco area. Samples that represent the range of water-quality conditions in the San Francisco area are shown in a trilinear diagram (fig. 5). Trilinear diagrams are used to show the relative proportions of common cations and anions, thereby allowing comparison and classification of water samples with different concentrations (Hem, 1985). This type of diagram also is useful for showing the effects of mixing water from two different sources. If two different waters are combined, the composition of the mixture will be proportional to the relative quantities of each as long as chemical reactions do not occur. Intermediate compositions of the mixture consequently will plot on a trilinear diagram along a straight line connecting the two source compositions. Most ground water in the study area is a mixed cation, bicarbonate type. Urban and natural factors may shift ion proportions to a sodium chloride type water. Ion exchange also may alter the proportions of cations in water and thereby produce ground water with a composition other than a simple mixture of water from different sources (Todd, 1980). The major anions generally are stable and conservative during mixing in local shallow ground water.

Selected water-quality data for the San Francisco area are summarized in table 17 (at back of report). Additional water-quality data for the San Francisco area are presented by Hamlin and Yates (1990) and Yates and others (1990). Concentrations of most major dissolved constituents in local ground water are within guidelines recommended by the U.S. Environmental Protection Agency (1986). However, nitratenitrogen in ground water commonly exceeds the primary maximum contaminant level of $10 \mathrm{mg} / \mathrm{L}$ (U.S. Environmental Protection Agency, 1986).

Primary drinking-water standards are based on anticipated health effects. Nitrate-nitrogen concentrations greater than $10 \mathrm{mg} / \mathrm{L}$ in water may cause methemoglobinemia (blue-baby disease) when used for infant feeding. Ten of 22 sites sampled in the San Francisco area had nitrate-nitrogen concentrations of $10 \mathrm{mg} / \mathrm{L}$ or greater. The concentrations ranged from 12 to $36 \mathrm{mg} / \mathrm{L}$, and most concentrations were between 12 and $20 \mathrm{mg} / \mathrm{L}$ (table 2). 


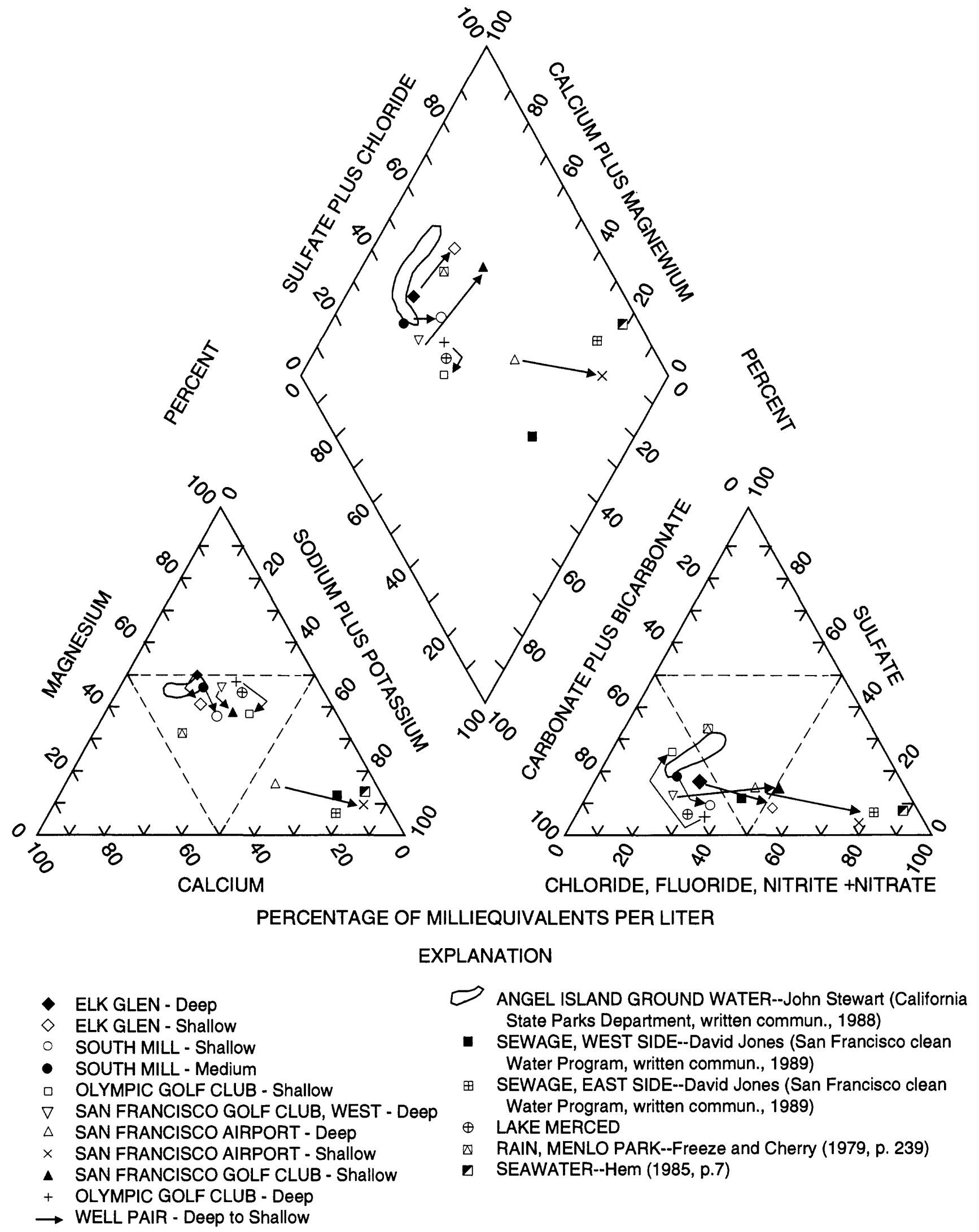

Figure 5. Quality of ground water, rain, sewage, and seawater in the San Francisco area. 
Table 2. Boron, methylene blue active substance, and nitrogen species in ground water in San Francisco and part of San Mateo Counties

[Well name or sample source: HLA, Harding-Lawson Associates. D, deep; S, shallow. Depth of well in feet below land surface. $\mu \mathrm{g} / \mathrm{L}$, microgram per liter; $\mathrm{mg} / \mathrm{L}$, milligram per liter. <, actual value is less than value shown. na, not applicable]

\begin{tabular}{|c|c|c|c|c|c|c|c|c|c|}
\hline $\begin{array}{l}\text { Map } \\
\text { No. } \\
\text { (pl. 2A) }\end{array}$ & $\begin{array}{l}\text { Well name or } \\
\text { sample source }\end{array}$ & State well No. & $\begin{array}{l}\text { Depth } \\
\text { of well }\end{array}$ & Date & $\begin{array}{c}\text { Boron, } \\
\text { dissolved } \\
(\mu \mathrm{g} / \mathrm{L})\end{array}$ & $\begin{array}{c}\text { Methylene, } \\
\text { blue active } \\
\text { substance } \\
(\mathrm{mg} / \mathrm{L})\end{array}$ & $\begin{array}{l}\text { Nitrogen, } \\
\text { ammonia, } \\
\text { dissolved } \\
(\mathrm{mg} / \mathrm{L})\end{array}$ & $\begin{array}{l}\text { Nitrogen, } \\
\text { nitrate, } \\
\text { dissolved } \\
(\mathrm{mg} / \mathrm{L})\end{array}$ & $\begin{array}{c}\text { Nitrogen, } \\
\mathrm{NO}_{2}+\mathrm{NO}_{3}, \\
\text { dissolved } \\
(\mathrm{mg} / \mathrm{L})\end{array}$ \\
\hline 1 & Adam Grant Building & $2 S / 5 W-3 C_{1}$ & 135 & $1-08-91$ & 130 & 0.09 & 0.03 & $<0.01$ & 7.1 \\
\hline 3 & Mt. Zion Hospital & $2 \mathrm{~S} / 5 \mathrm{~W}-5 \mathrm{~L} 1$ & 500 & $1-10-91$ & 110 & .18 & .03 & $<.01$ & 18 \\
\hline 4 & St. Anne's Home & $2 \mathrm{~S} / 5 \mathrm{~W}-6 \mathrm{M} 1$ & 80 & $1-08-91$ & 80 & .12 & .03 & $<.01$ & 9.6 \\
\hline 6 & Davies Hospital & $2 \mathrm{~S} / 5 \mathrm{~W}-8 \mathrm{P} 1$ & 230 & $1-10-91$ & 150 & .12 & .03 & .09 & 13 \\
\hline 10 & AC Electric & $2 \mathrm{~S} / 5 \mathrm{~W}-27 \mathrm{~L} 1$ & 100 & $1-09-91$ & 70 & .12 & .04 & .07 & 15 \\
\hline 11 & Brussels Street & $2 \mathrm{~S} / 5 \mathrm{~W}-27 \mathrm{~N} 1$ & 20 & $1-09-91$ & 130 & .23 & .04 & .46 & 36 \\
\hline 12 & Herz Playground & $2 \mathrm{~S} / 5 \mathrm{~W}-33 \mathrm{~L} 1$ & 81 & $1-08-91$ & 30 & .21 & .04 & $<.01$ & 6.6 \\
\hline 14 & Presidio 6 & $2 \mathrm{~S} / 6 \mathrm{~W}-2 \mathrm{H} 1$ & 60 & $1-10-91$ & 50 & .07 & .03 & $<.01$ & 6.4 \\
\hline 17 & Elk Glen-D & $2 S / 6 W-11 R 1$ & 360 & $1-10-91$ & 40 & .10 & .03 & $<.01$ & 12 \\
\hline 18 & Elk Glen-S & $2 S / 6 W-11 R 2$ & 72 & $1-10-91$ & 50 & .11 & .08 & .02 & 10 \\
\hline 19 & French Hospital & $2 \mathrm{~S} / 6 \mathrm{~W}-12 \mathrm{~A} 1$ & 100 & $1-10-91$ & 50 & .19 & .04 & $<.01$ & 20 \\
\hline 21 & Arboretum 5 & $2 \mathrm{~S} / 6 \mathrm{~W}-12 \mathrm{Q} 2$ & 250 & $1-10-91$ & 100 & .14 & .04 & $<.01$ & 18 \\
\hline 30 & HLA E & $2 S / 6 W-15 P 1$ & 68 & $1-09-91$ & 180 & .06 & .04 & $<.01$ & 7.6 \\
\hline 36 & HLA J & $2 S / 6 \mathrm{~W}-22 \mathrm{Q} 1$ & 66 & $1-09-91$ & 130 & .12 & .04 & $<.01$ & 12 \\
\hline 44 & Zoo 03 & $2 \mathrm{~S} / 6 \mathrm{~W}-27 \mathrm{~B} 5$ & 220 & $1-09-91$ & 40 & .08 & .09 & $<.01$ & 8.9 \\
\hline 51 & Olympic Golf Club-S & $2 \mathrm{~S} / 6 \mathrm{~W}-35 \mathrm{Q} 1$ & 51 & $1-09-91$ & 40 & .12 & .29 & .02 & .90 \\
\hline 53 & $\begin{array}{l}\text { San Francisco } \\
\text { Golf Club West-D }\end{array}$ & $2 \mathrm{~S} / 6 \mathrm{~W}-36 \mathrm{~N} 2$ & 540 & $1-09-91$ & 30 & .03 & .10 & $<.01$ & .80 \\
\hline na & $\begin{array}{l}\text { San Francisco } \\
\text { Airport-D }\end{array}$ & $3 \mathrm{~S} / 5 \mathrm{~W}-34 \mathrm{~L} 1$ & 141 & $1-08-91$ & 1,100 & .81 & 22 & $<.01$ & $<.10$ \\
\hline na & $\begin{array}{l}\text { San Francisco } \\
\text { Airport-S }\end{array}$ & $3 \mathrm{~S} / 5 \mathrm{~W}-34 \mathrm{~L} 2$ & 35 & $1-09-91$ & 30 & .05 & .07 & .02 & 12 \\
\hline 56 & Olympic Golf Club-D & $3 \mathrm{~S} / 6 \mathrm{~W}-2 \mathrm{~B} 3$ & 524 & $1-09-91$ & 30 & .08 & .04 & $<.01$ & 5.6 \\
\hline 58 & $\begin{array}{l}\text { Spring, south bank } \\
\text { of Lobos Creek }\end{array}$ & 2S/6W- 1MS1 & na & $1-08-91$ & 100 & .07 & .04 & .04 & 6.5 \\
\hline 59 & $\begin{array}{l}\text { Spring, north bank } \\
\text { of Lobos Creek }\end{array}$ & $2 \mathrm{~S} / 6 \mathrm{~W}-2 \mathrm{JS} 1$ & na & $1-08-91$ & 110 & .07 & .30 & .03 & 1.0 \\
\hline
\end{tabular}

Water from the shallow well at San Francisco Airport (table 17) exceeds the secondary maximum contaminant level (SMCL) of $250 \mathrm{mg} / \mathrm{L}$ for chloride (U.S. Environmental Protection Agency, 1986). Secondary drinking-water standards are based on the esthetic character of the water. A salty taste becomes noticeable in water when chloride concentration exceeds $250 \mathrm{mg} / \mathrm{L}$. Water from the shallow airport well (table 17) also exceeds the SMCL's for iron $(300$ $\mu \mathrm{g} / \mathrm{L})$ and manganese $(50 \mu \mathrm{g} / \mathrm{L})$ set by the U.S. Environmental Protection Agency (1986).

The water from many wells in the San Francisco area can be considered hard. Hardness commonly is reported in terms of equivalent concentrations of calcium carbonate $\left(\mathrm{CaCO}_{3}\right)$. Hem (1985) presents the classification for degree of hardness shown in table 3. Using this classification, hardness data for 56 wells were evaluated. The percentages of wells in each range were 2 percent (soft), 5 percent (moderately hard), 14 percent (hard), and 79 percent (very hard). Although not a health problem, excessive hardness reduces the effectiveness of soap and may be considered to represent the soap-consuming capacity of a water (Hem, 1985). Most of the observed effect with soap results from calcium and magnesium.

\section{COMPARISON OF SHALLOW AND DEEP GROUND WATER}

The concentrations of most major dissolved constituents, such as chloride and nitrate, decrease with 
Table 3. Classification for degree of hardness (Hem, 1985)

[mg/L, milligram per liter]

\begin{tabular}{lll}
\hline $\begin{array}{l}\text { Hardness range } \\
\left(\mathrm{mg} / \mathrm{L} \text { as } \mathrm{CaCO}_{3}\right)\end{array}$ & \multicolumn{1}{l}{ Description } \\
\hline $0-60 \ldots \ldots \ldots \ldots \ldots \ldots \ldots \ldots \ldots \ldots$ & Soft \\
$61-120 \ldots \ldots \ldots \ldots \ldots \ldots \ldots$ & Moderately hard \\
$121-180 \ldots \ldots \ldots \ldots \ldots \ldots$ & Hard \\
Greater than $180 \ldots \ldots \ldots \ldots \ldots$ & Very hard \\
\hline
\end{tabular}

depth in the ground-water system (Yates and others, 1990). This phenomenon results from the shallow distribution of contamination sources (sewers, irrigation-return flow, etc.) in the urban environment. Data describing ground-water quality for Angel Island are shown in figure 5 (John Stewart, California State Parks Department, written commun., 1988). These data represent a ground-water composition primarily controlled by geologic factors and not affected by urban activities. When compared with San Francisco ground water, the Angel Island ground water can be inferred to describe preurban conditions in the city, and can allow evaluation of the effect of urbanization on ground-water quality. Water from wells in the San Francisco area shows intermediate compositions between Angel Island ground water (natural conditions) and sewage/seawater compositions (fig. 5). Because of the large percentage of seawater in sewage, particularly on the east side, sewage composition plots near that of seawater. Pairs of wells tapping shallow (less than $100 \mathrm{ft}$ ) and deep (greater than $100 \mathrm{ft}$ ) ground water are shown in figure 5. Deep ground water from all wells sampled is associated more closely with natural, preurban conditions. Shallow ground water, except at the Olympic Golf Club site, is more closely related to sewage/seawater compositions. Shallow ground water at the Olympic Golf Club site may be showing the effects of surface-water infiltration. Deep and shallow ground water from wells at the San Francisco Airport plots near sewage/saltwater compositions, although the shallow ground water shows the strongest correlation.

Stable-isotope data for San Francisco show trends similar to major-ion compositions (fig. 6, table 4). Sewage from western San Francisco and municipal water have similar isotopic compositions that represent urban conditions. Stable-isotope ratios for ground water lie within the range of values for rain water. Shallow wells at all sites yielded isotopic ratios that are closer to sewage/municipal water composition than related deep-well compositions. Isotopic values for samples from Lake Merced lie to the right of the meteoric line and indicate concentration of heavy isotopes by evaporation.

\section{CHARACTERIZATION OF NITRATE SOURCES}

The most common contaminant in ground water is dissolved nitrogen in the form of nitrate (Freeze and Cherry, 1979). The primary avenues of nitrate contamination in the San Francisco area are through irrigation-return flow (fertilizers) and leakage from sewers. Nitrate $\left(\mathrm{NO}_{3}^{-}\right)$in ground water generally originates from nitrate sources on the land surface, in the soil zone, or in shallow subsoil zones. Nitrogen from fertilizers and sewage also may be in the form of ammonium $\left(\mathrm{NH}_{4}^{+}\right)$or ammonia $\left(\mathrm{NH}_{3}\right)$. Under the oxidizing conditions generally found above and in shallow ground water, these species are converted to nitrate. Nitrogen fixation by bacteria in the soil and decomposition of plant residue also add nitrogen to ground water. In deep ground water, under reducing conditions, nitrate may be converted to nitrous oxide or nitrogen. If the water then moves into the unsaturated zone, these gases may be lost to air in the unsaturated zone.

\section{FERTILIZERS}

In residential areas, fertilizers may add the greatest quantity of nitrate to shallow ground water, when compared with other sources. Baier and Rykbost (1976) noted that high nitrate concentrations in ground water from the Southold Township on Long Island, New York, primarily were attributed to fertilizers. Another study of ground water in Central Long Island by Flipse and others (1984) reached a similar conclusion; the largest source of nitrogen was from cultivation sources (mineralized soil nitrogen or fertilizers) rather than human or animal wastes. Denver (1989) identified positive correlations between nitrate and other ions related to fertilizer applications in a study of shallow ground water in eastern Sussex County, Delaware.

The magnitude of nitrate contribution to ground water from fertilizers is obscured by input from sewage. To differentiate between the two sources, selected ground-water samples in the San Francisco area were analyzed for boron, methylene blue active substance (MBAS), and nitrogen species. These data are shown in table 2 . Boron concentrations in sewage are high as a result of the use of borax cleansers. 


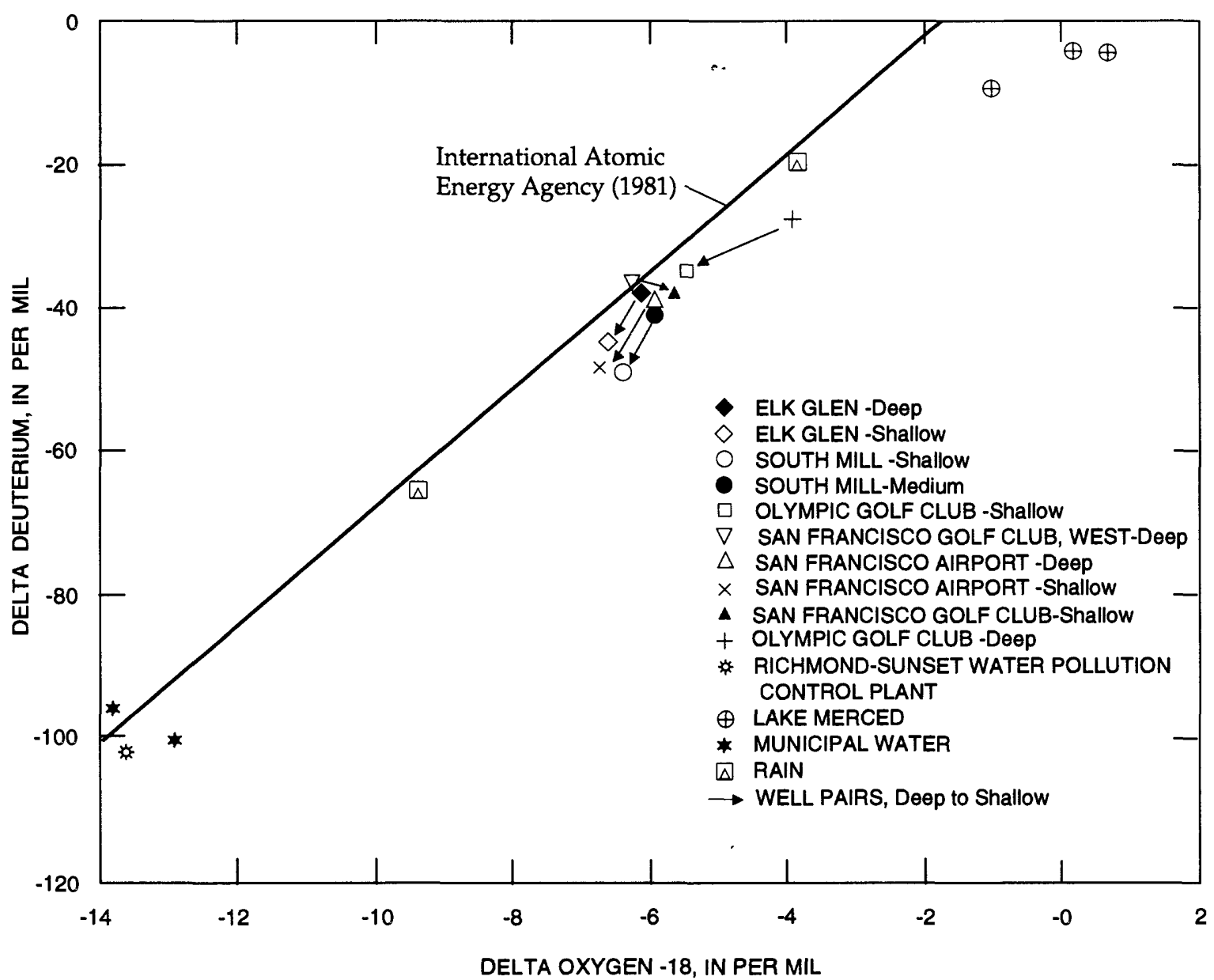

Figure 6. Stable-isotope data for ground water, Lake Merced, rainwater, municipal water, and influent sewage in San Francisco and part of San Mateo Counties.

Conversely, boron should be low in waters primarily derived from irrigation-return flow. However, seawater has a high concentration of boron and may mask differences between fertilizer and sewage sources, where present. Detergents are determined with MBAS analysis and indicate sewage contamination. Low MBAS values may indicate the absence of sewage or that the detergents have been chemically decomposed and removed from solution.

Sites in table 2 that have low boron and MBAS concentrations indicate fertilizers as the primary source of boron. Wells in or downgradient of large irrigated areas that show this effect include those at St. Anne's Home, Herz Playground, Elk Glen Lake, and the San Francisco Zoo (site 44). Data from wells at golf courses (San Francisco Golf Club, Olympic Golf Club) also are consistent with fertilizers as a primary source of nitrate. The well at AC Electric is downgradient of an area historically devoted to nurseries and farming operations. Boron and MBAS data indicate that the high concentration of nitrate primarily may be derived from fertilizers.

\section{SEWAGE}

Although sewers are designed to be water-tight, they allow exchange of sewage and ground water in the San Francisco area. In most areas of the city, sewer pipes lie above the water table and may allow sewage to leak to the shallow ground water. As mentioned in the previous section, the effects of sewage and fertilizer on ground-water quality are similar. Katz and others (1980) studied nitrogen distribution in shallow ground water from sewered and unsewered areas in Nassau County, New York. They concluded that a lack of significant difference in nitrate concentrations between the two areas was due in part to sampling bias, the long residence time of contaminated water in the aquifer system, and to nitrate sources (fertilizers and animal waste) that are unaf- 
Table 4. Stable-isotope ratios for ground water, surface water, and rain water in San Francisco and part of San Mateo Counties

[Well name or sample source: D, deep; M, medium; S, shallow. Depth of well in feet below land surface. na, not applicable]

\begin{tabular}{|c|c|c|c|c|c|c|}
\hline $\begin{array}{l}\text { Map } \\
\text { No. } \\
\text { (pl. 2A) }\end{array}$ & $\begin{array}{l}\text { Well name or } \\
\text { sample source }\end{array}$ & State well No. & $\begin{array}{l}\text { Depth } \\
\text { of well }\end{array}$ & Date & $\begin{array}{l}\text { Hydrogen-2/ } \\
\text { hydrogen-1 } \\
\text { (per mil) }\end{array}$ & $\begin{array}{c}\text { Oxygen-18/ } \\
\text { oxygen-16 } \\
\text { (per mil) }\end{array}$ \\
\hline 17 & Elk Glen-D & $2 \mathrm{~S} / 6 \mathrm{~W}-11 \mathrm{R} 1$ & 360 & $\begin{array}{r}3-02-88 \\
5-04-88 \\
12-06-89\end{array}$ & $\begin{array}{l}-36 \\
-34 \\
-39\end{array}$ & $\begin{array}{l}-6.1 \\
-6.3 \\
-6.0\end{array}$ \\
\hline $\begin{array}{l}18 \\
24 \\
25 \\
51 \\
53\end{array}$ & $\begin{array}{l}\text { Elk Glen-S } \\
\text { South Mill-M } \\
\text { South Mill-S } \\
\text { Olympic Golf Club-S } \\
\text { San Francisco Golf Club, } \\
\text { West-D }\end{array}$ & $\begin{array}{l}2 S / 6 W-11 R 2 \\
2 S / 6 W-15 C 4 \\
2 S / 6 W-15 C 5 \\
2 S / 6 W-35 Q 1 \\
2 S / 6 W-36 N 2\end{array}$ & $\begin{array}{r}72 \\
140 \\
57 \\
51 \\
540\end{array}$ & $\begin{array}{r}12-06-89 \\
12-04-89 \\
12-04-89 \\
12-06-89 \\
5-02-88\end{array}$ & $\begin{array}{l}-46 \\
-42 \\
-50 \\
-36 \\
-38\end{array}$ & $\begin{array}{l}-6.5 \\
-5.8 \\
-6.3 \\
-5.4 \\
-6.1\end{array}$ \\
\hline $\begin{array}{l}\text { na } \\
\text { na } \\
55 \\
56\end{array}$ & $\begin{array}{l}\text { San Francisco Airport-D } \\
\text { San Francisco Airport-S } \\
\text { San Francisco Golf Club-S } \\
\text { Olympic Golf Club-D }\end{array}$ & $\begin{array}{l}3 \mathrm{~S} / 5 \mathrm{~W}-34 \mathrm{~L} 1 \\
3 \mathrm{~S} / 5 \mathrm{~W}-34 \mathrm{~L} 2 \\
3 \mathrm{~S} / 6 \mathrm{~W}-2 \mathrm{~A} 1 \\
3 \mathrm{~S} / 6 \mathrm{~W}-2 \mathrm{~B} 3\end{array}$ & $\begin{array}{r}141 \\
35 \\
62 \\
524\end{array}$ & $\begin{array}{r}12-07-89 \\
12-07-89 \\
12-07-89 \\
11-19-87 \\
3-01-88 \\
5-02-88\end{array}$ & $\begin{array}{l}-40 \\
-49 \\
-38 \\
-32 \\
-29 \\
-30\end{array}$ & $\begin{array}{l}-5.8 \\
-6.6 \\
-5.6 \\
-3.8 \\
-3.8 \\
-4.0\end{array}$ \\
\hline 63 & $\begin{array}{l}\text { Richmond Sunset Water } \\
\text { Pollution Control Plant, } \\
\text { influent sewage }\end{array}$ & na & na & $5-18-89$ & -102 & -13.6 \\
\hline na & Lake Merced at boathouse & na & na & $\begin{array}{r}11-17-87 \\
3-01-88 \\
5-02-88\end{array}$ & $\begin{array}{r}-6 \\
-11 \\
-6\end{array}$ & $\begin{array}{r}.8 \\
-.9 \\
.3\end{array}$ \\
\hline na & Municipal water & na & na & $\begin{array}{l}3-01-88 \\
5-02-88\end{array}$ & $\begin{array}{r}-96 \\
-100\end{array}$ & $\begin{array}{l}-13.8 \\
-12.9\end{array}$ \\
\hline na & Rain water & na & na & $\begin{array}{r}11-19-87 \\
2-29-88\end{array}$ & $\begin{array}{l}-19 \\
-66\end{array}$ & $\begin{array}{l}-3.6 \\
-9.3\end{array}$ \\
\hline
\end{tabular}

fected by leaking sewers. In a similar study, Porter (1980) noted that concentrations of nitrate in ground water produced by fertilizers were sufficiently high, when compared with human wastewater, to mask the effect of leaking sewers.

Boron and MBAS concentrations in ground water previously have been used to evaluate contamination by sewage. Barber and others (1988) used boron to map the extent of ground-water contamination by sewage near Boston, Massachusetts. Boron was a good indicator of contamination because (1) it was unique to the sewage source, (2) there was a significant contrast in its concentration in contaminated and native ground water, and (3) it had the same distri- bution as the "conservative" solute chloride. Sodium tetraborate (borax) is widely used as a cleaning aid; therefore, boron may be present in sewage and industrial wastes (Hem, 1985). Barber and others (1988) identified that the zone of high MBAS consisted of relatively nonbiodegradable branched-chain alkylbenzene sulfonic acid (ABS) anionic surfactants that were introduced into the aquifer system between about 1950 and 1965. In 1965, these detergents were replaced by the readily degradable linear-chain alkylbenzene sulfonic acid (LAS). Similarly, high values of MBAS in the San Francisco ground-water system are indicative of a sewer source; however, low values may either indicate the absence of a sewer source or the degradation of post-1965 detergents present in 
sewage. Le Blanc (1984) determined that boron and chloride were transported conservatively in a groundwater study at Cape Cod, Massachusetts. Boron and chloride also are present in seawater and could be indicators of seawater intrusion. The potential use of boron isotope analysis to distinguish between marine and terrestrial sources is discussed later.

In the absence of seawater contamination, sites in table 2 that show high boron and MBAS concentrations indicate sewage as the primary source of nitrate. Wells that clearly show this effect are at Mt. Zion Hospital, Brussels Street, and at the San Francisco Airport. The shallow well at the San Francisco Airport probably is contaminated with a significant quantity of sewage and bay water. High concentrations of MBAS and ammonia indicate sewage contamination, whereas the excessively high boron $(1,100$ $\mu \mathrm{g} / \mathrm{L})$ and chloride $(3,100 \mathrm{mg} / \mathrm{L})$ concentrations indicate the presence of bay water (saltwater). The occurrence of nitrogen in the form of ammonia may indicate close proximity to a sewer leak and (or) reducing conditions in the ground water. The leaky sewer pipe may have been a conduit for the infiltration of bay water, as well as a source of nitrogen.

\section{DISTRIBUTION OF NITRATE AND TRITIUM NEAR LAKE MERCED}

The concentrations of nitrate-nitrogen in shallow ground water upgradient of Lake Merced are high and average about $10 \mathrm{mg} / \mathrm{L}$. The principal sources of nitrate probably are leaking sewer pipes and fertilizers applied to urban landscaping. Fertilization of adjacent golf courses probably contributes a small percentage to the total quantity of nitrate because of the small area they occupy and because only one golf course is upgradient of the lake.

Nitrate data are consistent with flow patterns in the shallow and deep parts of the aquifer system. Nitrate-nitrogen in shallow ground water upgradient of Lake Merced ranges from 5 to $17 \mathrm{mg} / \mathrm{L}$ (Yates and others, 1990). Biological processes in the lake rapidly consume nitrate-nitrogen yielding an ambient concentration that is less than $0.1 \mathrm{mg} / \mathrm{L}$. Hamlin and Yates (1990) found that shallow wells on the downgradient side of the lake also have relatively low nitratenitrogen concentrations (less than $1.0 \mathrm{mg} / \mathrm{L}$ ), which confirms that water from the lake flows into the shallow aquifer and reaches the wells. They also found that deep wells on the downgradient side of the lake have lower nitrate-nitrogen concentrations $(0.8$ to $5.6 \mathrm{mg} / \mathrm{L})$ than deep wells on the upgradient side $(8.1$ to $14 \mathrm{mg} / \mathrm{L})$. This indicates that lake water is reaching the deep part of the aquifer system.
The distribution of tritium in ground water around Lake Merced (table 5) is consistent with flow to the aquifer induced by nearby pumping in the deep part of the aquifer (Robert Michel, U.S. Geological Survey, written commun., 1991). Tritium is a radioactive isotope of hydrogen that commonly is used to determine the relative age of ground water. Large quantities of tritium were introduced into the environment through atmospheric tests of nuclear weapons from 1952 to the early 1960's (Michel, 1990). The tritium concentration of water is expressed in tritium units (TU), where $1 \mathrm{TU}$ is the equivalent of 1 tritium atom in $10^{18}$ hydrogen atoms. Before 1952, the natural concentration of tritium in precipitation ranged from 1 to $10 \mathrm{TU}$ (International Atomic Energy Agency, 1983). Recharge from surface-water sources that entered the ground-water system before 1952 presently would have a tritium concentration of less than $2 \mathrm{TU}$ because tritium decays with time and has a half-life of 12.4 years. Recharge from surface-water sources since 1952 shows variable tritium concentrations that generally increased to a peak in 1963 and subsequently decreased following the end of atmospheric testing of nuclear weapons (Michel, 1990). Near Lake Merced, tritium concentrations in ground water are close to present-day concentrations ( 5 to $10 \mathrm{TU}$ ) to a depth of $50 \mathrm{ft}$ below the water table (table 5). The 1963 peak was not observed in ground water near Lake Merced (Robert Michel, U.S. Geological Survey, written commun., 1991). These observations indicate that pumping of deep ground water near Lake Merced has induced flow of water from the lake to the groundwater system.

\section{SEAWATER CONTAMINATION}

Chloride is the major anion in seawater and it moves through aquifers at nearly the same rate as the intruding water. Increasing chloride concentrations in ground water may be the first indication of seawater contamination (Hem, 1985). In an area where no other source of saline contamination exists, high chloride concentrations indicate seawater contamination. However, sewage also is a source of chloride in San Francisco.

Dissolved constituents other than chloride can be used to help identify seawater contamination, but difficulties are encountered while using them. Magnesium is present in seawater in much greater concentration than calcium; therefore, a low calcium-tomagnesium ratio may indicate the presence of seawater. The presence of sulfate in anionic proportion 
Table 5. Tritium concentrations in ground water, surface water, and seawater in San Francisco and part of San Mateo Counties

[Well location or sample source: HLA, Harding-Lawson Associates. D, deep; M, medium; S, shallow. Depth of well in feet below land surface. TU, tritium unit. na, not applicable]

\begin{tabular}{|c|c|c|c|c|c|}
\hline $\begin{array}{c}\text { Map } \\
\text { No. } \\
\text { (pl. 2A) }\end{array}$ & $\begin{array}{l}\text { Well name or } \\
\text { sample source }\end{array}$ & State well No. & $\begin{array}{l}\text { Depth } \\
\text { of well }\end{array}$ & Date & $\begin{array}{c}\text { Tritium, } \\
\text { in water } \\
\text { molecules } \\
\text { (TU) }\end{array}$ \\
\hline 3 & Mt. Zion Hospital & $2 \mathrm{~S} / 5 \mathrm{~W}-5 \mathrm{~L} 1$ & 500 & $4-03-90$ & 20.3 \\
\hline 6 & Davies Hospital & $2 \mathrm{~S} / 5 \mathrm{~W}-8 \mathrm{P} 1$ & 230 & $5-16-89$ & 20.6 \\
\hline 12 & Herz Playground & $2 \mathrm{~S} / 5 \mathrm{~W}-33 \mathrm{~L} 1$ & 81 & $4-02-90$ & 15.4 \\
\hline 15 & Windmill Northeast & $2 S / 6 W-10 L 1$ & 156 & $5-18-89$ & 15 \\
\hline \multirow[t]{2}{*}{17} & Elk Glen-D & $2 \mathrm{~S} / 6 \mathrm{~W}-11 \mathrm{R} 1$ & 360 & $4-04-90$ & 1.5 \\
\hline & & & & $5-18-89$ & 1.1 \\
\hline 18 & Elk Glen-S & $2 S / 6 W-11 R 2$ & 72 & $4-04-90$ & 22.1 \\
\hline 22 & HLA B & $2 S / 6 W-15 C 1$ & 65 & $4-04-90$ & 28 \\
\hline 24 & South Mill-M & $2 S / 6 W-15 C 4$ & 140 & $4-04-90$ & 2.9 \\
\hline 25 & South Mill-S & $2 S / 6 W-15 C 5$ & 57 & $4-04-90$ & 19.6 \\
\hline 30 & HLA E & $2 S / 6 W-15 P 1$ & 68 & $5-18-89$ & 10.3 \\
\hline 46 & HLA V & $2 S / 6 W-27 J 1$ & 53 & $4-03-90$ & 8 \\
\hline 49 & Fort Funston-S & $2 S / 6 W-34 J 3$ & 278 & $4-05-90$ & 3.7 \\
\hline 51 & Olympic Golf Club-S & $2 S / 6 W-35 Q 1$ & 51 & $4-03-90$ & 5.8 \\
\hline na & San Francisco Airport-D & $3 \mathrm{~S} / 5 \mathrm{~W}-34 \mathrm{L1}$ & 141 & $4-02-90$ & .1 \\
\hline na & San Francisco Airport-S & $3 \mathrm{~S} / 5 \mathrm{~W}-34 \mathrm{~L} 2$ & 35 & $4-02-90$ & 5.9 \\
\hline 55 & San Francisco Golf Club-S & $3 \mathrm{~S} / 6 \mathrm{~W}-2 \mathrm{~A} 1$ & 62 & $4-03-90$ & 5.7 \\
\hline 56 & Olympic Golf Club-D & $3 \mathrm{~S} / 6 \mathrm{~W}-2 \mathrm{~B} 3$ & 524 & $5-16-89$ & 8.2 \\
\hline 57 & Spring at McNab Lake & $2 \mathrm{~S} / 5 \mathrm{~W}-33 \mathrm{BS} 1$ & na & $5-16-89$ & 6.9 \\
\hline 58 & Spring, south bank of Lobos Creek & $2 \mathrm{~S} / 6 \mathrm{~W}-1 \mathrm{MS} 1$ & na & $4-05-90$ & 13.6 \\
\hline 59 & Spring, north bank of Lobos Creek & $2 S / 6 W-2 J S 1$ & na & $4-05-90$ & 18.1 \\
\hline 60 & Mt. Davidson Spring & $2 \mathrm{~S} / 6 \mathrm{~W}-25 \mathrm{AS} 1$ & na & $5-16-89$ & 6.5 \\
\hline na & Lake Merced at boathouse & na & na & $8-31-89$ & 7.3 \\
\hline na & Seawater & na & na & $10-16-89$ & 2.5 \\
\hline
\end{tabular}

(for example, $\mathrm{Cl}: \mathrm{SO}_{4}$ ) similar to that of seawater also may indicate contamination. However, because cation exchange with fine-grained sediments in the aquifer matrix and sulfate-reduction reactions during mixing with ground water commonly occur when seawater is introduced, the proportions of anions and cations in the first contaminated water to reach the sampling point cannot be expected to be exactly the same as those of a simple mixture of seawater and fresh water (Hem, 1985).

Minor constituents of seawater also can help determine the presence of seawater or other saline contamination. Piper and others (1953) used variations of boron, iodide, and barium to help differen- tiate between contamination by seawater and connate brine. Seawater contains about $4.5 \mathrm{mg} / \mathrm{L}$ of boron. Because boron and chloride travel conservatively through the aquifer without chemical reaction, the chloride-to-boron ratio should remain fairly constant without input from other sources (such as sewage). The bromide concentration in seawater is about 65 $\mathrm{mg} / \mathrm{L}$ and also may indicate contamination. However, bromide may be derived from other sources such as the gasoline additive, ethylene dibromide. Additionally, bromide selectively may be concentrated by clay-membrane effects because the bromide ion is larger than the chloride ion (Hem, 1985). Thus, use of chloride-to-bromide ratios to detect contamination by seawater is complicated in urban areas and in areas 
Table 6. Chloride-boron and chloride-bromide ratios for ground water, surface water, sewage, and seawater in San Francisco and part of San Mateo Counties during winter 1988 and spring 1989-90

[Well name or sample source: HLA, Harding-Lawson Associates. D, deep; M, medium; S, shallow. Depth of well in feet below land surface. $\mathrm{mg} / \mathrm{L}$, milligram per liter. --, no data. na, not applicable]

\begin{tabular}{|c|c|c|c|c|c|c|c|}
\hline $\begin{array}{c}\text { Map } \\
\text { No. } \\
\text { (pl. 2A) }\end{array}$ & $\begin{array}{l}\text { Well name or } \\
\text { sample source }\end{array}$ & State well No. & $\begin{array}{l}\text { Depth } \\
\text { of well }\end{array}$ & $\begin{array}{l}\text { Chloride } \\
(\mathrm{mg} / \mathrm{L})\end{array}$ & $\begin{array}{c}\text { Bromide } \\
(\mathrm{mg} / \mathrm{L})\end{array}$ & $\begin{array}{c}\text { Chloride: } \\
\text { boron }\end{array}$ & $\begin{array}{l}\text { Chloride: } \\
\text { bromide }\end{array}$ \\
\hline 1 & Adam Grant Building & $2 S / 5 W-3 C 1$ & 135 & 170 & 0.57 & 1,308 & 298 \\
\hline 3 & Mt. Zion Hospital & $2 \mathrm{~S} / 5 \mathrm{~W}-5 \mathrm{Ll} 1$ & 500 & 49 & .31 & 400 & 158 \\
\hline 4 & St. Anne's Home & $2 \mathrm{~S} / 5 \mathrm{~W}-6 \mathrm{M} 1$ & 80 & 67 & .25 & 838 & 268 \\
\hline 6 & Davies Hospital & $2 \mathrm{~S} / 5 \mathrm{~W}-8 \mathrm{P} 1$ & 230 & 33 & .39 & 227 & 85 \\
\hline 10 & AC Electric & $2 \mathrm{~S} / 5 \mathrm{~W}-27 \mathrm{~L} 1$ & 100 & 58 & .23 & 771 & 252 \\
\hline 11 & Brussels Street & $2 \mathrm{~S} / 5 \mathrm{~W}-27 \mathrm{~N} 1$ & 20 & 49 & .47 & 369 & 104 \\
\hline 12 & Herz Playground & $2 \mathrm{~S} / 5 \mathrm{~W}-33 \mathrm{~L} 1$ & 81 & 35 & .14 & 1,167 & 250 \\
\hline 14 & Presidio 6 & $2 \mathrm{~S} / 6 \mathrm{~W}-2 \mathrm{H} 1$ & 60 & 41 & .18 & 800 & 228 \\
\hline 15 & Windmill Northeast & $2 \mathrm{~S} / 6 \mathrm{~W}-10 \mathrm{~L} 1$ & 156 & 36 & .12 & -- & 300 \\
\hline 16 & Windmill Northwest & $2 \mathrm{~S} / 6 \mathrm{~W}-10 \mathrm{~L} 2$ & 281 & 47 & .16 & -- & 294 \\
\hline 17 & Elk Glen-D & $2 \mathrm{~S} / 6 \mathrm{~W}-11 \mathrm{R} 1$ & 360 & 41 & .16 & 1,050 & 256 \\
\hline 18 & Elk Glen-S & $2 \mathrm{~S} / 6 \mathrm{~W}-11 \mathrm{R} 2$ & 72 & 210 & 1.3 & 4,200 & 162 \\
\hline 19 & French Hospital & $2 \mathrm{~S} / 6 \mathrm{~W}-12 \mathrm{~A} 1$ & 100 & 74 & .22 & 1,440 & 336 \\
\hline 21 & Arboretum 5 & $2 \mathrm{~S} / 6 \mathrm{~W}-12 \mathrm{Q} 2$ & 250 & 31 & .23 & 280 & 135 \\
\hline 23 & South Mill-D & $2 S / 6 W-15 C 3$ & 400 & 35 & .11 & -- & 318 \\
\hline 24 & South Mill-M & $2 S / 6 W-15 C 4$ & 140 & 38 & .12 & -- & 317 \\
\hline 25 & South Mill-S & $2 S / 6 W-15 C 5$ & 57 & 100 & .33 & -- & 303 \\
\hline 30 & HLA E & $2 \mathrm{~S} / 6 \mathrm{~W}-15 \mathrm{P} 1$ & 68 & 130 & .45 & 694 & 289 \\
\hline 36 & HLA J & $2 S / 6 W-22 Q 1$ & 66 & 65 & .24 & 692 & 271 \\
\hline 44 & Zoo 03 & $2 S / 6 W-27 B 5$ & 220 & 42 & .20 & 1,050 & 210 \\
\hline 51 & Olympic Golf Club-S & $2 S / 6 W-35 Q 1$ & 51 & 21 & .04 & 525 & 525 \\
\hline 53 & $\begin{array}{l}\text { San Francisco Golf } \\
\text { Club West-D }\end{array}$ & $2 S / 6 W-36 N 2$ & 540 & 47 & .24 & 1,600 & 196 \\
\hline na & San Francisco Airport-S & $3 \mathrm{~S} / 5 \mathrm{~W}-34 \mathrm{~L} 2$ & 35 & 3,100 & 11 & 2,820 & 282 \\
\hline 55 & San Francisco Golf Club-S & $3 \mathrm{~S} / 6 \mathrm{~W}-2 \mathrm{~A} 1$ & 62 & 73 & .15 & 2,430 & 444 \\
\hline 56 & Olympic Golf Club-D & $3 \mathrm{~S} / 6 \mathrm{~W}-2 \mathrm{~B} 3$ & 524 & 67 & .26 & 2,330 & 296 \\
\hline 58 & $\begin{array}{l}\text { Spring, south bank } \\
\text { of Lobos Creek }\end{array}$ & $2 \mathrm{~S} / 6 \mathrm{~W}-1 \mathrm{MS} 1$ & na & 37 & .28 & 320 & 132 \\
\hline 59 & $\begin{array}{l}\text { Spring, north bank } \\
\text { of Lobos Creek }\end{array}$ & $2 \mathrm{~S} / 6 \mathrm{~W}-2 \mathrm{JS} 1$ & na & 40 & .37 & 382 & 108 \\
\hline 63 & $\begin{array}{l}\text { Richmond-Sunset Water } \\
\text { Pollution Control Plant, } \\
\text { influent sewage }\end{array}$ & na & na & $100-200$ & -- & $400-500$ & -- \\
\hline na & Pacific Ocean, Sloat Avenue & na & na & 18,000 & 60 & -- & 300 \\
\hline na & Seawater (Hem, 1985, p. 7) & na & na & 19,000 & 67 & 4,220 & 284 \\
\hline
\end{tabular}

where significant clay minerals are present in the aquifer. Detection and tracing of seawater contamination using stable isotopes of hydrogen and oxygen, or long-lived radioactive isotopes such as carbon-14, may have considerable potential (Hem, 1985).
Ratios of conservative ions can be used to help identify seawater contamination. Table 6 lists chloride-to-boron and chloride-to-bromide ratios along with concentrations of chloride and bromide for selected sites in the San Francisco area. Boron concen- 
trations were presented previously in table 2 . The chloride-to-boron ratio for seawater is 4,220 , whereas the ratio for influent sewage is 400 to 500 . The chloride-to-bromide ratio for seawater is about 300 . This ratio in ground water is useful in areas where urban input is insignificant and clay minerals are not dominant among aquifer materials. Water from several wells shows evidence of seawater contamination based on these data. The shallow well at Elk Glen Lake has a chloride-to-boron ratio nearly identical to seawater and a high concentration of chloride ( 210 $\mathrm{mg} / \mathrm{L}$ ) when compared with average ground water (about $50 \mathrm{mg} / \mathrm{L}$ ). The chloride-to-bromide ratio is significantly different from that of seawater, but may have been altered by extensive clay minerals in the shallow aquifer at this location. The source of this contamination may be seawater used in the Steinhart Aquarium, either leakage from the nearby supply pipe or leakage of return flow in the nearby sewer line. The saltwater pipeline for Steinhart Aquarium and sewer line that drains waste saltwater also are close to the shallow observation well at South Mill. The chloride-to-bromide ratio for water from this well is identical to that of seawater and chloride concentration is high $(100 \mathrm{mg} / \mathrm{L})$ when compared with average ground water (about $50 \mathrm{mg} / \mathrm{L}$ ). Shallow wells at Elk Glen Lake and South Mill are susceptible to contamination because of their close proximity to large irrigation wells. These irrigation wells produce cones of depression in the water table that could capture contaminated water.

Water from the shallow well at San Francisco Airport shows evidence of seawater and sewage contamination. Seawater contamination is supported by high chloride concentration $(3,100 \mathrm{mg} / \mathrm{L})$, a chlorideto-bromide ratio identical to seawater, and a chlorideto-boron ratio approaching that of seawater. High concentrations of ammonia-nitrogen and MBAS compounds indicate sewage contamination in this well (table 2). The sewer pipe also may have been a conduit for infiltration of bay water, which commonly occurs in sewer outfalls along the east side of San Francisco. Seawater contamination is indicated in the well at the Adam Grant Building based on high chloride concentration $(170 \mathrm{mg} / \mathrm{L})$, a high chloride-toboron ratio $(1,308)$, and a chloride-to-bromide ratio (298) equivalent to seawater composition. There also is some evidence for seawater contamination in water from wells at the Olympic Golf Club and the San Francisco Golf Club. The water levels in deep wells at the golf courses are about $40 \mathrm{ft}$ below sea level, which establishes a steep hydraulic gradient inland from the Pacific Ocean. Production wells in Daly City to the south have lowered hydraulic heads in the deep aquifer to more than $100 \mathrm{ft}$ below sea level. Chloride concentrations are not high in the golf club wells, whereas chloride-to-boron ratios are high $(1,600$ to 2,330$)$ in the deep wells, approaching seawater composition $(4,220)$. Wells at the North Windmill (sites 15 and 16) are near the Pacific Ocean in Golden Gate Park. Again, chloride concentrations are low, but chloride-to-bromide ratios are identical to seawater. Ion ratios may indicate the presence, but not necessarily the magnitude, of seawater contamination. Potential seawater contamination may be assessed by monitoring changes in chloride concentration and ion ratios with time. A rapid increase in chloride concentration coupled with ion ratios approaching seawater composition would indicate seawater intrusion.

Previous studies have not concluded that there is evidence of seawater intrusion in San Francisco. Bartell (1913) presented water-quality data for two wells that showed chloride concentrations that were higher than average, but were significantly lower than those in seawater. A study of seawater intrusion along the coast in 1958 found no evidence of intrusion in San Francisco (California Department of Water Resources, 1958). Evidence presented in this section may not be indicative of seawater intrusion. In many instances, supposed evidence of seawater intrusion actually may be the result of infiltration of seawater into sewer lines and subsequent leakage to ground water. Also, present and historical seawater intrusion cannot be differentiated without age-dating techniques. For example, in the early 1900's, pumping in the downtown section of San Francisco caused ground-water levels to decline below sea level. This could have resulted in seawater intrusion at that time and residual saltwater may be present at the current time. Ground-water pumping also can draw connate water from fine-grained deposits that were formed in a marine environment. Unexpected sources, as in Golden Gate Park, also can be misleading. The apparent saltwater contamination in shallow wells at Golden Gate Park probably is a result of leakage of seawater used at Steinhart Aquarium, either from the supply pipe or exfiltration of saltwater discharge to the sewer system.

\section{ESTIMATION OF GROUND-WATER RECHARGE}

Ground-water recharge is a primary component of the water budget of the ground-water system in San Francisco. Ground-water recharge is defined here as water added to the ground-water system through per- 
colation of rainfall, irrigation water to the water table, or leakage from underground pipes. Other major components of the water budget are subterranean outflow to San Francisco Bay, the Pacific Ocean, and outflow across the San Francisco-San Mateo County line. Ground-water recharge is the most important component of the water budget because it represents the long-term limit of ground-water development for San Francisco.

Ground-water recharge was estimated using a set of variables and equations collectively described as a hydrologic routing model. The following equation shows the factors considered in the calculation of ground-water recharge:

RECHARGE $=$ ZWLEAK + SLEAK + RCHIMP+RCHIRR +RCHNON,

where

ZWLEAK is leakage from water-delivery pipes;

SLEAK is leakage from sewer pipes;

RCHIMP is recharge from leakage through impervious areas;

RCHIRR is recharge from irrigated areas; and

RCHNON is recharge from nonirrigated areas.

For reference, all variables and equations used in the hydrologic routing model are presented in Appendixes 1 and 2 and table 18 (at back of report). The hydrologic routing model includes factors associated with climate, land and water use, irrigation, leakage from underground pipes, rainfall runoff, and evapotranspiration. Municipal water delivery and sewer flow also are simulated by the hydrologic routing model. Because municipal water delivery and sewer flow are measured and depend on all or part of the factors listed above, they were used to calibrate the model.

Sewer flow is calculated as follows:

$$
\begin{gathered}
\text { SEWERFLOW }=\text { WW +ROFFIMP } \\
+ \text { ROFFIRR +ROFFNON, }
\end{gathered}
$$

where

WW is wastewater;

ROFFIMP is runoff from impervious areas;

ROFFIRR is runoff from irrigated areas; and

ROFFNON is runoff from nonirrigated areas.

The hydrologic routing model simulates hydrologic processes on a temporal basis. The model primarily was used for simulating a 2-year period on a monthly basis, but also was used to simulate individual storms on a daily basis. The data used to calibrate the model and to estimate ground-water recharge were from water years 1987 to 1988 . A water year begins on October 1, and ends on September 30. The first year of a continuing drought in California was 1987. " Before 1987, an important component of sewer-flow data is missing that precludes accurate calibration of the hydrologic routing model. Consequently, the calculated values of ground-water recharge for water years $1987-88$ probably are lower than they would be under average climatic conditions.

The areal distribution of ground-water recharge was addressed by applying the hydrologic routing model to different areas within San Francisco. These areas were discretized on the basis of land use, soil type, and average annual rainfall. San Francisco was divided into 83 polygons, which hereafter will be referred to as land-use zones. Many of the variables associated with the hydrologic routing model are zone-dependent. For reference, the values of these variables used in the calibrated model are shown in table 19 (at back of report). Lake Merced (land-use zone 2) was treated different than other zones. Rainfall on Lake Merced that averages about $21.5 \mathrm{in} / \mathrm{yr}$ is virtually ground-water recharge because Lake Merced is a water-table lake with direct hydraulic connection to the ground-water flow system. However, evaporation from Lake Merced is greater than rainfall, at about 26.4 in. for water year 1988 (Yates and others, 1990). Isotope data (fig. 6) confirm that evaporation generally exceeds rainfall at Lake Merced. Therefore, ground-water recharge from Lake Merced was not allowed to occur.

\section{CLIMATE}

\section{TEMPERATURE}

Temperature data are required for the estimation of evapotranspiration, which is an important component of the hydrologic cycle. San Francisco weather is characterized by mild temperatures as a result of the moderating effect of the Pacific Ocean and San Francisco Bay. Average daily temperatures at the Richmond-Sunset WPCP weather station range from $45^{\circ} \mathrm{F}$ in January to $69^{\circ} \mathrm{F}$ in September. In addition to the Richmond-Sunset WPCP station, the National Oceanic and Atmospheric Administration (NOAA) maintains two other weather stations on the northern peninsula: one at the San Francisco International Airport (immediately south of the study area on the eastern side of the peninsula), and one in downtown San Francisco. The downtown station was at the Federal Office Building (FOB) through 1983 and was moved to Mission Dolores in 1984. 


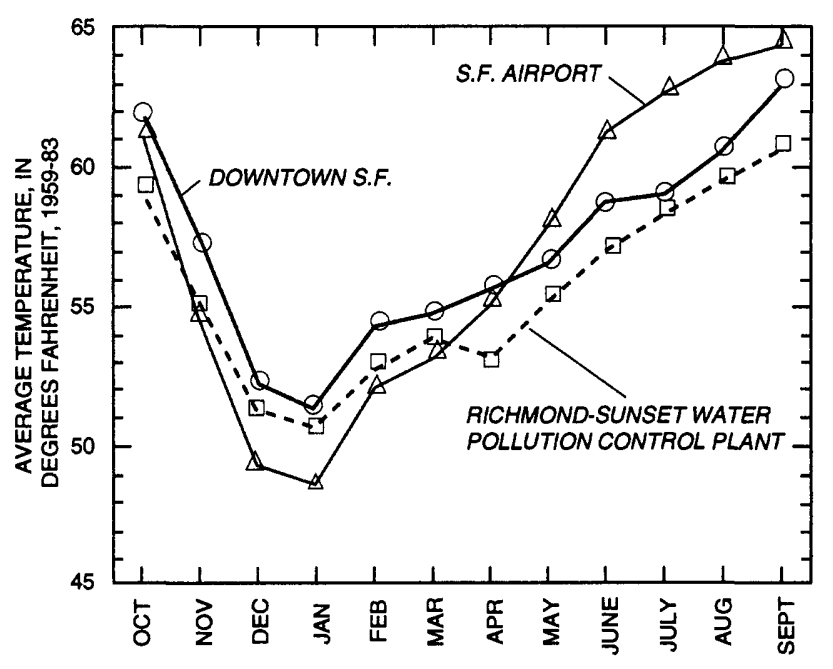

Figure 7. Average monthly temperature at three weather stations in San Francisco and part of San Mateo Counties, 1959-83.

The temperature record was less than 50 percent complete at the Richmond-Sunset WPCP station for the calibration period of water years 1987-88. The missing data, therefore, were estimated for that period from data available at the airport station. Records of average temperatures at the three weather stations from 1959 to 1983 are shown on a monthly basis in figure 7. These data were used to determine the average monthly temperature differences among stations. The average monthly temperature differences were used to estimate the missing temperature records for the Richmond-Sunset WPCP station based on the measured temperatures at the airport station. Measured temperatures at the airport station for water years 1987-88 are shown in table 7.

\section{RAINFALL}

Rainfall is a source of ground-water recharge and is a primary input variable to the hydrologic routing model. Estimation of the areal distribution of groundwater recharge requires estimation of the areal distribution of rainfall. To estimate the areal distribution of rainfall, contour maps of annual average rainfall were developed from available data. Rainfall records were obtained for 39 rain gages in San Francisco and San Mateo Counties from the San Francisco Clean Water Program (CWP), California Department of Water Resources (DWR), and National Oceanic and Atmospheric Administration (NOAA). The San Mateo County Department of Public Works provided a rainfall map that was compiled in 1960.
Table 7. Monthly average measured temperatures at San Francisco Airport, water years 1987-88

$\left[{ }^{\circ} \mathrm{F}\right.$, degree Fahrenheit $]$

\begin{tabular}{|c|c|c|}
\hline \multirow[b]{2}{*}{ Month } & \multicolumn{2}{|c|}{ Monthly average temperature $\left({ }^{\circ} \mathrm{F}\right)$} \\
\hline & $\begin{array}{c}\text { Water year } \\
1987\end{array}$ & $\begin{array}{c}\text { Water year } \\
1988\end{array}$ \\
\hline October & 61.4 & 63.9 \\
\hline November . . . . . & 57.1 & 57.0 \\
\hline December ...... & 50.3 & 50.3 \\
\hline January . . . . . . & 49.3 & 50.6 \\
\hline February $\ldots \ldots$ & 53.3 & 54.5 \\
\hline March $\ldots \ldots \ldots$ & 54.9 & 56.5 \\
\hline April $\ldots \ldots \ldots$ & 59.2 & 58.1 \\
\hline May $\ldots \ldots \ldots \ldots$ & 61.6 & 59.5 \\
\hline June $\ldots \ldots \ldots$ & 62.4 & 62.5 \\
\hline July $\ldots \ldots \ldots \ldots$ & 63.1 & 65.3 \\
\hline August $\ldots \ldots \ldots$ & 65.1 & 65.0 \\
\hline September . . . . . . & 64.0 & 63.1 \\
\hline
\end{tabular}

Table 8. Average annual rainfall at the National Oceanic and Atmospheric Administration gage at the Federal Office Building in San Francisco

\begin{tabular}{lc}
\hline \multicolumn{1}{c}{$\begin{array}{c}\text { Averaging } \\
\text { period } \\
\text { (water years) }\end{array}$} & $\begin{array}{c}\text { Average annual } \\
\text { rainfall } \\
\text { (inches) }\end{array}$ \\
\hline 1849-1985 (period of record) & 21.52 \\
$1945-84$ (recent 40 years) & 19.92 \\
$1955-84$ (recent 30 years) & 19.86 \\
$1965-84$ (recent 20 years) & 20.48 \\
$1975-84$ (recent 10 years) & 18.99 \\
$1976-83$ & 19.79 \\
\hline
\end{tabular}

Historical records for the NOAA FOB station, which was moved to Mission Dolores in 1984, are available from 1849 to 1984 . These historical records were used to select a modern period of record that represents average rainfall for the last 30 to 40 years. Table 8 shows average rainfall at the FOB station for several periods of record, and for the period from 1976 to 1983 , which was selected as representative of average rainfall for the 30 to 40 year time frame. The 1976-83 average (19.79 in.) is lower than that for the period of record ( $21.52 \mathrm{in}$.) because rainfall was significantly greater in the late 19th century than during the 20 th century.

Average annual rainfall for $1976-83$ was calculated using data from the 39 rain gages. These aver- 
age values were used to develop maps of average annual rainfall for San Francisco County and parts of San Mateo County. The county maps were developed in different ways because data availability was much greater in San Francisco: 30 of the 39 rain gages are in San Francisco County.

A preliminary rainfall map of San Francisco County showed that there were several rainfall stations with anomalous readings, including the FOB station. Jerry Johnson (San Francisco Clean Water Program, oral commun., August 1988) confirmed that the FOB station was under-reporting rainfall, hence the move to Mission Dolores in 1984. Three additional stations were assumed to have similar problems and were not used in subsequent analysis. The preliminary map also showed an increase in rainfall with altitude. Although the relation between altitude and rainfall is not strong statistically (correlation coefficient of 0.31 ), the apparent increase in rainfall with altitude was preserved while redrawing the rainfall map.

Preliminary lines of equal rainfall in San Mateo County were developed using the sparse data available. The general patterns of the 1960 rainfall map were respected, and the magnitude of rainfall was adjusted according to data from nine rain gages in the area. The resulting rainfall lines do not respect every data point.

Plate $2 C$ shows the location of the rain gages, the 1976-83 mean for each gage, and the interpreted rainfall lines in San Francisco and San Mateo Counties. The smooth lines in plate $2 C$ do not respect every data point because there is considerable variability in the data; however, regional rainfall patterns apparent in the data were preserved.

\section{LAND AND WATER USE}

\section{LAND USE}

Land use is a key factor in the estimation of areal ground-water recharge. The city and county of San Francisco was divided into 83 zones on the basis of land use and population density. Significant changes in soil type and average annual rainfall also were taken into consideration. The relation between population and total water use on the west side, and northern and southern parts of the east side of San Francisco is shown in table 9. The values in table 9 show that there is a direct correlation between popula-
Table 9. Population density and water use in San Francisco, 1970

[Water use: Data from San Francisco Department of Public Works (1975). acre-ft/d, acre-foot per day]

\begin{tabular}{lcccc}
\hline Area & Population & $\begin{array}{c}\text { Percentage } \\
\text { of total } \\
\text { population }\end{array}$ & $\begin{array}{c}\text { Water } \\
\text { use } \\
\text { (acre-ft/d) }\end{array}$ & $\begin{array}{c}\text { Percentage } \\
\text { of total } \\
\text { water use }\end{array}$ \\
\hline $\begin{array}{l}\text { Richmond- } \\
\text { Sunset }\end{array}$ & ${ }^{1} 229,865$ & 25 & 59.1 & 23 \\
Southeast & ${ }^{2} 166,251$ & 18 & 47.9 & 18 \\
North Point & ${ }^{3} 533,000$ & 57 & 151.4 & 59 \\
\hline
\end{tabular}

${ }^{1}$ San Francisco Department of Public Works (1974b)

${ }^{2}$ San Francisco Department of Public Works (1974c)

${ }^{3}$ San Francisco Department of Public Works (1974a)

tion and water use. Population figures include tourists and commuters concentrated in the northeastern part of the city. Peak daytime population is about 37 percent greater than the resident population (San Francisco Department of Public Works, 1974a, $1974 b$, or 1974c).

Aerial photographs were used to define land-use zones of equal population density, and each land-use zone was assigned a relative indoor water-useintensity factor (ZWEIGHTR). ZWEIGHTR was used to calculate the percentage of total indoor water use allocated to each land-use zone. ZWEIGHTR was arbitrarily assigned a value of 1 for low-density residential areas, and a maximum value of 15 in high-density areas. The range of ZWEIGHTR is proportional to the range of population between lowand high-density areas. Figure 8 shows the discretization of 83 land-use zones in San Francisco County and the areal distribution of ZWEIGHTR. Some zone numbers are greater than 83 because preliminary work included part of San Mateo County. The highest ZWEIGHTR is associated with downtown San Francisco (land-use zone 122) where there are many high-rise office buildings. The population density in zone 122 is about 275 percent greater than in any other land-use zone. The lowest values of ZWEIGHTR are associated with undeveloped areas (ZWEIGHTR $=0$ ), parks, golf courses, low-density developed areas, and other areas with minimal potential for indoor water use.

Other land-use factors associated with the zones shown in figure 8 include the percentage of impervious area in each land-use zone, the percentage of pervious area that is irrigated, and the percentage of each 
land-use zone covered by a body of water. These areas were determined by digitizing parts of largescale black-and-white or infrared aerial photographs covering various land-use zones. The resulting percentages of area in each category for various land-use zones were extrapolated to zones with similar characteristics. The ZWEIGHTR and other land-use factors associated with each of the land-use zones are presented in table 19.

\section{WATER USE}

About 99 percent of the water used in San Francisco is imported from Hetch Hetchy and other reservoirs and delivered through municipal supply lines. The remaining 1 percent is ground water primarily pumped for irrigation. These figures do not include other sources of water such as Lobos Creek, which is diverted for potable use, and Lake Merced, from which water is pumped for street cleaning and irrigation. The percentage of municipal water used indoors is of primary importance to this study. Indoor water use is an important component of sewer flow; about 98 percent of water used indoors becomes sewer flow (California Department of Water Resources, 1983). This value of 98 percent is used in the hydrologic routing model as the fraction of indoor water use that becomes wastewater (WWFRAC). Sewer flow and municipal flow, which are used in calibrating the hydrologic routing model, are important for recharge calculations because leakage from pipes is a significant source of recharge in San Francisco.

Ten years of municipal delivery data from 1978 to 1987 (San Francisco Water Department, written commun., 1988) were used to calculate the average monthly total use as a fraction of annual total use (table 10). Table 10 shows that the month with the smallest fraction of annual use is February, which is partly a result of the relatively small number of days in that month. There is clearly a seasonal influence in the data, with relatively high water use in the summer and relatively low water use in the winter. Outdoor water use, which is primarily for irrigation, is highly seasonal, but some evidence indicates that indoor use also varies seasonally.

The seasonal variability of indoor water use was analyzed using municipal delivery data from the San Francisco Water Department for 17 apartment buildings (21 or 22 units each) with little or no outside use of water for irrigation (Cheryl K. Davis, written commun., May 1990). These municipal delivery data were used to calculate monthly indoor water use as a fraction of annual indoor water use (table 10, column B). The values in table 10 show that indoor water use varies seasonally in the same manner as total water use, but at a lower magnitude. The indoor water use values in table 10 were reexpressed as fractions of total monthly use by assuming there is no outdoor use in February. A multiplier was used to change the February value for indoor use to the corresponding value for total use. The same multiplier was applied to the indoor use values for the remaining months, which resulted in monthly estimates of indoor use as a fraction of annual total use (table 10, column C). Table 10 also shows the estimated monthly indoor use as a fraction of monthly total use, which was used in the hydrologic routing model (FRACIND in appendixes 1 and 2).

Figure 9 shows the estimated temporal distribution of indoor and outdoor water use as described above. The estimated values indicate that outdoor use, calculated by subtracting indoor water use from total municipal water use, is a relatively small component of total municipal water use-about 5.8 percent. An independent estimate of outdoor use was made using irrigation consumption data provided by the San Francisco Water Department (Cheryl K. Davis, written commun., June 1988). These data from May 1987 through April 1988, reportedly are not completely reliable, but are the best available. The volume of irrigation water estimated by the San Francisco Water Department is 5.4 percent of the annual total municipal water use. This compares well with the earlier estimate of 5.8 percent of the annual total municipal water use.

Outdoor water use in San Francisco is assumed to be primarily for irrigation, whereas a small percentage probably is used for hosing driveways, washing cars, and other outdoor uses. In addition to municipal water, ground water is used in some parts of the city for irrigation. Ground-water pumpage was measured or estimated for all known active wells, which are primarily in Golden Gate Park and the golf courses. These ground-water pumpage values were used to estimate the percentage of total demand for irrigation water that was supplied by ground water. These percentages were calculated for each land-use zone and used to allocate water sources in the hydrologic routing model (FRACGW in appendixes 1 and 2). 


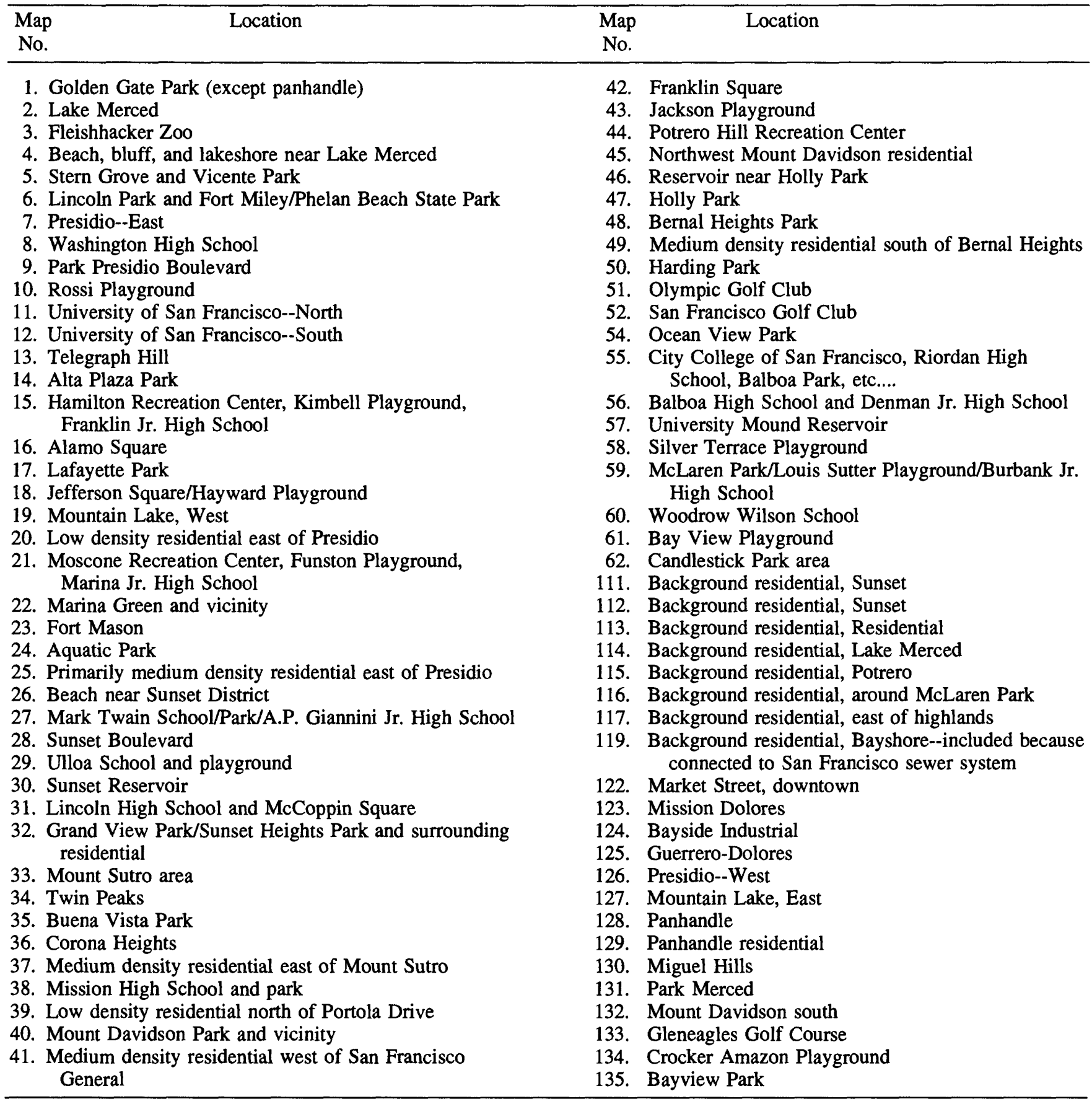

\section{SOURCES OF RECHARGE}

\section{INFILTRATION OF RAINFALL}

Rainfall in San Francisco lands on impervious areas, irrigated pervious areas, or nonirrigated pervious areas. For a given land-use zone, the quantity of rainfall that infiltrates, and the percentage of infiltration that becomes ground-water recharge, is highly dependent on the proportion of these three areas in the zone. Rainfall is calculated for a given zone and time period using the ratios between the value on the rainfall map for the zone and the average annual rainfall at each of the three NOAA stations. These ratios are multiplied by the measured rainfall over the given time period for the NOAA stations, resulting in adjusted values of rainfall that respect the measured values and the rainfall map. The average of these three values then is used to avoid large areal fluctuations in rainfall values as a result of local storms. 

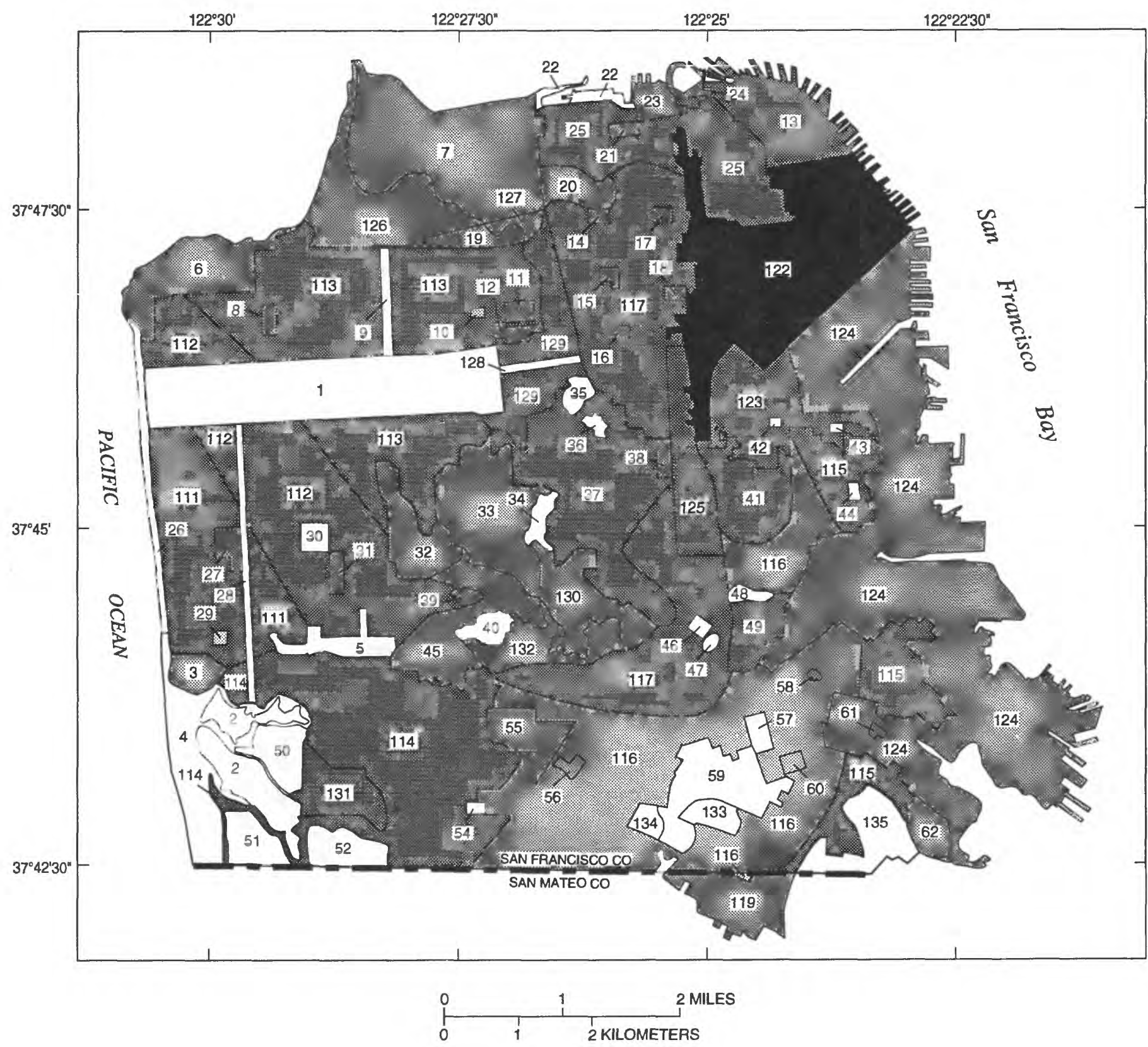

\section{EXPLANATION}

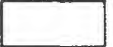

VERY LOW DENSITY (ZWEIGHTR less than 0.1)

LOW DENSITY (ZWEIGHTR 0.1 to 1 )

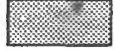

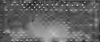

MEDIUM DENSITY (ZWEIGHTR greater than 1 to 10)

Figure 8. Land use in San Francisco, April 1989.

Rainfall on impervious areas will either run off to sewers or surrounding pervious areas, accumulate in depressions, or leak through cracks in the impervious material. Depression storage on impervious areas was estimated to be $0.2 \mathrm{in} / \mathrm{mo}$ during those months where rainfall was at least $0.2 \mathrm{in} / \mathrm{mo}$. The fraction of impervious areas that allows leakage or runoff to pervious areas (FRIMPLK) was estimated for each land-use 
Table 10. Estimation of monthly indoor water use as a fraction of monthly total water use in San Francisco

[Annual total use (C): Calculated by assuming no outdoor water use in February, and adjusting all values in (B) by the ratio of $\mathrm{A} / \mathrm{B}$ for February. Monthly total use (FRACIND): Ratio of C/A]

\begin{tabular}{|c|c|c|c|c|}
\hline Month & $\begin{array}{c}\text { (A) } \\
\text { Average monthly } \\
\text { total water use } \\
\text { as a fraction of } \\
\text { annual total use } \\
1978-87\end{array}$ & $\begin{array}{c}\text { (B) } \\
\text { Average monthly } \\
\text { indoor water use } \\
\text { as a fraction of } \\
\text { annual indoor use } \\
1989-90\end{array}$ & $\begin{array}{l}(\mathrm{C}) \\
\text { Estimated monthly } \\
\text { indoor water use } \\
\text { as a fraction of } \\
\text { annual total use }\end{array}$ & $\begin{array}{l}\text { Estimated monthly } \\
\text { indoor water use } \\
\text { as a fraction of } \\
\text { monthly total use } \\
\text { (FRACIND) }\end{array}$ \\
\hline$\ldots \ldots \ldots$ & 0.0783 & 0.0835 & 0.0783 & 1.0 \\
\hline February $\ldots \ldots \ldots$ & .0731 & .0777 & .0731 & 1.0 \\
\hline March $\ldots \ldots \ldots \ldots$ & .0814 & .0856 & .0805 & .989 \\
\hline April $\ldots . \ldots \ldots$ & .0819 & .0841 & .0791 & .966 \\
\hline May . . . . . . . . & .0892 & .0884 & .0832 & .933 \\
\hline June $\ldots \ldots \ldots \ldots$ & .0887 & .0846 & .0796 & .897 \\
\hline July $\ldots \ldots \ldots \ldots$ & .0921 & .0865 & .0814 & .884 \\
\hline August $\ldots \ldots \ldots \ldots$ & .0913 & .0857 & .0807 & .884 \\
\hline September . . . . . . . & .0867 & .0807 & .0759 & .876 \\
\hline October $\ldots \ldots \ldots$ & .0838 & .0814 & .0766 & .914 \\
\hline November . . . . . . . . & .0761 & .0797 & .0750 & .986 \\
\hline December ....... & .0774 & .0818 & .0770 & .995 \\
\hline
\end{tabular}

zone (table 19). Estimation of depression storage and FRIMPLK are discussed later in this report. Recharge from impervious surfaces was calculated by subtracting depression storage from the area-weighted rainfall and multiplying by FRIMPLK. Runoff from impervious surfaces to sewers was the remaining water that did not go into depression storage or become recharge.

Rainfall on irrigated areas will either flow to sewers, be used by plants (evapotranspiration), or become recharge. It was assumed that runoff from pervious areas to sewers would not take place in most land-use zones in the absence of a relatively extreme rainfall event. Maximum soil infiltration rates (Eric Vinson, U.S. Soil Conservation Service, written commun., June 1988) are greater than all but the most intense rainfall rates, which occur only for brief periods (Metcalf and Eddy, 1980, p. 4-22). Rainfall that does not run off and is not evapotranspired becomes recharge. Rainfall on nonirrigated pervious areas has the same fate as that on irrigated areas with the exception that more of the rainfall is likely to be evapotranspired in nonirrigated areas. The combination of a relatively dry soil profile and deep root zone gives nonirrigated areas a greater capacity for retaining rain water that eventually would be evapotranspired; thus, recharge is lower in nonirrigated

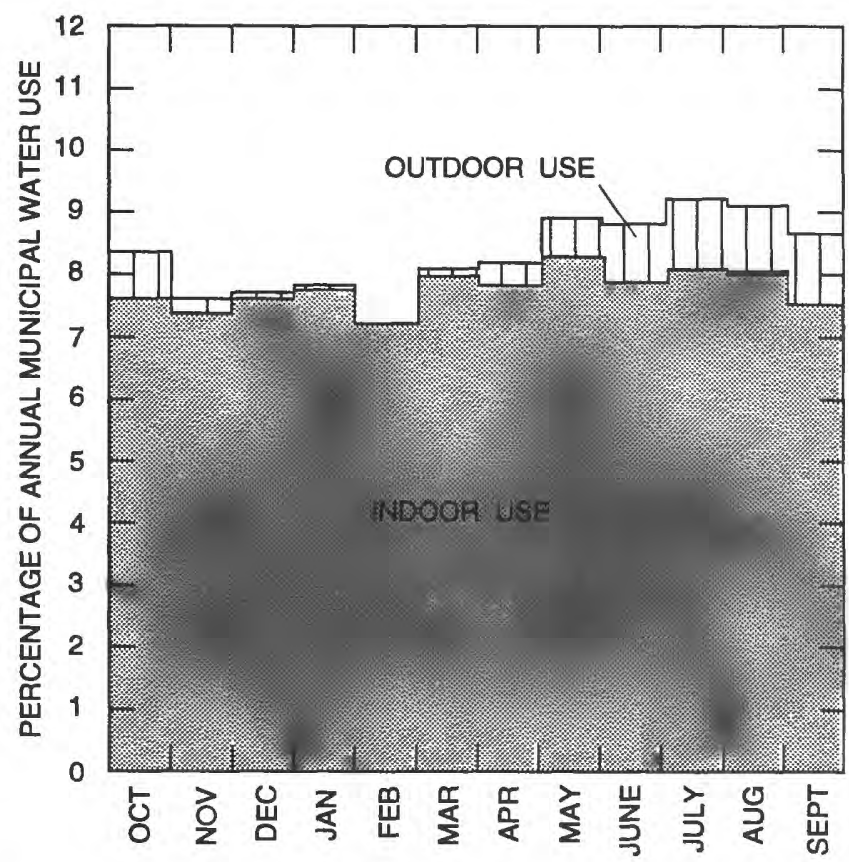

Figure 9. Estimated monthly indoor and outdoor water use in San Francisco, 1987-88. Average monthly total use is from table 10 , column A.

areas. Runoff, evapotranspiration, and recharge in nonirrigated areas are calculated as for irrigated areas. 
INFILTRATION OF IRRIGATION WATER

An efficient irrigation system would provide plants with exactly the required quantity of water at the rate at which they need it. The irrigation systems used in residential and other areas of San Francisco do not achieve 100 percent efficiency. Irrigation efficiency is defined as the percentage of irrigation water that is used by the plants; it is assumed that the remainder becomes ground-water recharge. For the purpose of this investigation, irrigation efficiency initially was assumed to be about 60 percent; however, efficiency was increased to 70 percent during calibration. Under normal circumstances, it probably is unlikely that irrigation efficiency would be as high as 70 percent, but under drought conditions (198788 ), conservation efforts probably were sufficient to cause this increase in irrigation efficiency.

Irrigation was initiated when soil moisture was depleted to the extent that the ratio of actual to potential evapotranspiration was less than a specified threshold. It was assumed that irrigation would commence when actual evapotranspiration decreased to less than 70 percent of the potential evapotranspiration. If rainfall for a given time period was insufficient to keep soil moisture above the threshold, irrigation was initiated. The volume of irrigation water applied was assumed to be the quantity required to increase the soil moisture to the maximum available water capacity at a 70-percent irrigation efficiency. The total volume of irrigation water unused by plants that becomes ground-water recharge is 30 percent. The hydrologic routing model indicates that about 49 percent of ground-water recharge in areas irrigated from rainfall and irrigation water (excluding leaks from water or sewer pipes and runoff from impervious surfaces) is from irrigation.

\section{LEAKAGE FROM WATER AND SEWER PIPES}

Leakage from water and sewer pipes probably is a significant source of recharge, particularly in densely populated urban areas. Leakage tests on municipal water-delivery pipes indicate a leakage rate of about 4 percent, which was assumed for this study (Pitometer Associates, 1987). The sewer system in San Francisco is a combined system that routes sewage and storm-drain flows through the same pipes. Sewer pipes are not tested for leakage on a regular basis in San Francisco. They are replaced when catastrophic breaks cause flooding or street damage. Most of the sewer pipes on the west side of San Francisco are 40 to 70 years old and are made of clay pipe with mortared joints or reinforced concrete (San Francisco Department of Public Works, 1974b). Those on the east side are older, dating as far back as the late 1800's (San Francisco Department of Public Works, 1974a). The principal variables that control the volumes of infiltration or exfiltration are the age and condition of the sewers and the types of joints used to connect the pipes. Kimmel (1972) attributed a rapid recovery of the water table after a decrease in ground-water pumping largely to a combination of leakage from sewer and water pipes on Long Island, New York.

The San Francisco Water Department's primary concern with sewer pipe leakage is inflow and infiltration into the sewer system because excess flow must be treated; inflow carries soil with it, which causes clogging; and cavities that can cause collapse can develop around the sewer pipe (Dan Champeau, San Francisco Water Department, oral commun., November 1988). Infiltration of ground water into sewers below the water table may range from 0.0001 to more than $0.040 \mathrm{Mgal} / \mathrm{d}$ per mile of sewer line (Miller, 1980). This report primarily concentrates on outflow from the sewer into the ground-water recharge system because this outflow may constitute a significant source of ground-water recharge and potentially harmful chemical constituents.

Sewers are designed to be water tight, but leakage of sewage into the ground or exfiltration is common, especially from old sewers (Todd, 1980, p. 317). Leakage rates from water and sewer pipes to the ground-water system may vary significantly with geographic location. The sewer system on the east side of San Francisco is older than that on the west side, and therefore is more likely to develop leaks. However, the location of the water table above the sewer system in some areas on the east side will tend to decrease the overall leakage rate. The sewer system on the west side predominantly is above the water table. Sewer pipe leakage was assumed to be the same as water pipe leakage (4 percent) for lack of better criteria. Water-quality data support the assumption that sewer water enters the ground-water system, but do not indicate the magnitude of leakage.

A water pipe leakage rate of 4 percent is lower than the national average of about 10 percent (Pitometer Associates, 1987), and some areas around the world have water and sewer pipe leakage rates in excess of 40 percent (Lerner, 1986). Nevertheless, using the above assumption, the hydrologic routing model indicates that leakage from municipal water and sewer pipes accounts for about 26 and 27 percent 
of the total recharge in San Francisco, respectively. Sewer-pipe leakage is greater than water-pipe leakage because of the significant volume of rainfall runoff that enters the sewers in addition to the municipal wastewater. Thirty-two percent of the total waterand sewer-pipe leakage occurs in the high-density downtown area (land-use zone 122). The population density and associated usage of water and sewer pipes is more than three times greater in this land-use zone than that in any other zone. In densely populated areas, it is clear that recharge is highly sensitive to the leakage rate of water and sewer pipes.

\section{RECHARGE INTERCEPTION}

Potential recharge in the study area is intercepted by two primary processes: rainfall runoff and evapotranspiration. Vegetation interception, which can be significant in some environments, was not accounted for in San Francisco.

\section{RAINFALL RUNOFF}

Rainfall runoff can occur on pervious or impervious surfaces. It was assumed that runoff of irrigation water is an insignificant component of total runoff. Runoff from pervious surfaces was assumed to be minimal because maximum soil infiltration rates (Eric Vinson, U.S. Soil Conservation Service, written commun., June 1988) are greater than all but the most intense rainfall rates, which only occur for brief periods (Metcalf and Eddy, 1980, p. 4-22). A linear relation between rainfall and runoff from pervious areas was established such that a threshold rainfall amount had to be surpassed for runoff to occur. The threshold value was assigned based on soil type, ranging from $3 \mathrm{in} / \mathrm{mo}$ for clayey soils to $9 \mathrm{in} / \mathrm{mo}$ for sandy soils, with a slope of 0.9 . These threshold rainfall values effectively eliminate rainfall runoff from pervious areas except during months of intense rainfall. This method may underpredict runoff from pervious areas during months where intense rainfall occurs on consecutive days. Results from the hydrologic routing model for water years 1987-88 indicate that rainfall runoff from pervious areas constitutes about 3 percent of total rainfall runoff.

Rainfall on impervious surfaces that does not accumulate in depressions, leak through cracks in the impervious surface, or runoff to pervious areas is assumed to enter the sewer system. Maximum depression storage on impervious areas was estimated by Overton and Meadows (1976) to range from 0.06 to 0.11 in. per storm. They also identified that the volume of depression storage was a function of slope. Another estimate of depression storage was 0.0825 in. per storm (Kibler, 1962). Assuming that depression storage is about 0.06 in. per storm in San Francisco because slopes are relatively high, the annual depression storage can be estimated by multiplying by the number of storms per year. There was an average of 30 storms per year in water years 1987-88, yielding an annual depression storage of 1.8 in., or an average monthly depression storage of 0.15 in. Because there is little or no rain in the summer months, the maximum monthly depression storage for months during which there was rain was estimated to be $0.2 \mathrm{in}$.

The fraction of leakage and runoff from impervious to pervious areas was estimated for a given land-use zone and generally was based on the fraction of impervious area in that zone. There generally is an inverse relation between the size of an impervious area and the fraction of runoff that leaks or drains to pervious areas. Using these values for the variables that control rainfall runoff, the hydrologic routing model routed about 78 percent of rainfall on impervious areas to the sewer, and the remainder was split evenly between depression storage and leakage or runoff to pervious areas, which becomes ground-water recharge.

\section{EVAPOTRANSPIRATION}

Evapotranspiration is the quantity of water used by plants for transpiration and building of plant tissue, and then evaporated from plant foliage and adjacent soil (U.S. Department of Agriculture, 1970). Potential evapotranspiration (PET) is the evapotranspiration that occurs under ideal conditions, including an unlimited supply of water. Blaney and Criddle (1950) developed a formula for calculating PET based on empirical correlations between evapotranspiration and climatic factors. The Blaney-Criddle formula has been used extensively and modified by subsequent workers (U.S. Department of Agriculture, 1970; Dunne and Leopold, 1978). The form of the Blaney-Criddle formula used in this investigation is as follows (U.S. Department of Agriculture, 1970):

$$
P E T=k_{c} k_{t} t\left(\frac{P}{100}\right),
$$

where

$P E T$ is potential evapotranspiration for a given month, in inches;

$k_{c}$ is a monthly crop coefficient reflecting the 
growth stage of vegetation, inches per degree Fahrenheit;

$k_{\mathrm{t}}$ is a climatic coefficient related to the mean air temperature $(0.0173 t-0.314)$ (dimensionless);

$t$ is mean air temperature, in degrees Fahrenheit; and

$P$ is percentage of annual daylight hours occurring in the month.

Reference evapotranspiration $\left(E T_{o}\right)$, which is a commonly published form of evapotranspiration, does not take into account the growth stage of the vegetation and is defined as follows:

$$
E T_{o}=\frac{P E T}{k_{c}}
$$

The mean air temperature used was that measured at the three NOAA stations discussed earlier in this report. The percentage of daylight hours is published in table form for various latitudes (U.S. Department of Agriculture, 1970). Composite values of the coefficient $k_{\mathrm{c}}$ representative of the vegetation mix in each zone were estimated from reported empirical $k_{c}$ values for turf, trees, and nonirrigated native vegetation (U.S. Department of Agriculture, 1970; Dunne and Leopold, 1978).

The actual evapotranspiration ( $A E T)$ is calculated on the basis of $P E T$, soil properties, and soil moisture. PET was calculated as described in equation 4. Moisture-related soil properties are controlled by the lithology or type of the soil. Soil types for each land-use zone were determined using soil survey maps provided by the U.S. Soil Conservation Service (Eric Vinson, written commun., June 1988). The soils in each land-use zone were categorized into one of four groups: sand, sandy loam, silty clay loam, or clay. The available water capacity of soil (AWCAP), which is dependent on soil type, is defined as follows:

$$
A W C A P=(F C-P W P) \times R D,
$$

where

$F C$ is volumetric moisture content at field capacity (dimensionless);

$P W P$ is permanent wilting point (dimensionless); and

$R D$ is root depth $(\mathrm{L})$.

Field capacity is the quantity of water that soil can hold against the pull of gravity. The permanent wilting point is reached when the water content of the soil is so low that the plant cannot withdraw enough water to sustain transpiration and the plant wilts.
Estimated root depths range from 12 to 36 in. for irrigated areas, and from 24 to 120 in. for nonirrigated areas (table 19). The available water content $(A W C)$ is defined here as the difference between field capacity and the permanent wilting point:

$$
A W C=F C-P W P .
$$

Values of $A W C$ were assigned to each land-use zone on the basis of soil type: $A W C$ is $0.06,0.10,0.12$, or $0.14 \mathrm{in} / \mathrm{in}$ of soil (root) depth for sand, sandy loam, silty clay loam, or clay, respectively. The resulting range of $A W C A P$ is from 0.72 to 16.8 in., which is similar to the range 0.72 to 19.2 in. calculated from data provided by the U.S. Soil Conservation Service (Eric Vinsor, written commun., June 1988). The U.S. Soil Conservation Service did not collect data at depths greater than 60 in., so the upper bound was calculated assuming a constant $A W C A P$ for depths greater than $60 \mathrm{in}$.

Total soil moisture for a given period of time can be broken into two components: initial soil moisture and moisture added through infiltration of rainfall or irrigation water. Initial soil moisture was estimated for the initial time step (about 85 percent of $A W C A P$ for irrigated areas, and about 15 percent of $A W C A P$ for nonirrigated areas). Calculated soil moisture values from the previous time steps were used for the subsequent time steps for the remainder of the simulation.

Calculation of $A E T$ is trivial if total soil moisture is greater than or equal to $A W C A P ; A E T$ is then equal to PET. If the soil moisture is less than AWCAP, $A E T$ is calculated using the graphical relation shown in figure 10. The curves in figure 10 show the relation between the ratios of $A E T$ to $P E T$ and $A W C$ to $A W C A P$ for various soil types and are similar to curves developed by Dunne and Leopold (1978) and used by Bauer and Vaccaro (1987).

During calibration of the hydrologic routing model, calculated $E T_{o}$ was decreased 30 percent to reflect the effect of coastal fog. Reference evapotranspiration has been estimated on a monthly basis throughout California (Pruitt and others, 1987; Snyder and others, 1987). These estimates are shown in table 11. The California Department of Water Resources (1975a) estimated that potential evapotranspiration in the San Francisco area is about 76 percent of annual pan evaporation. Yates and others (1990) compiled measured pan evaporation data from Lake Merced with modified regional pan evaporation data (California Department of Water Resources, 1975b) to 


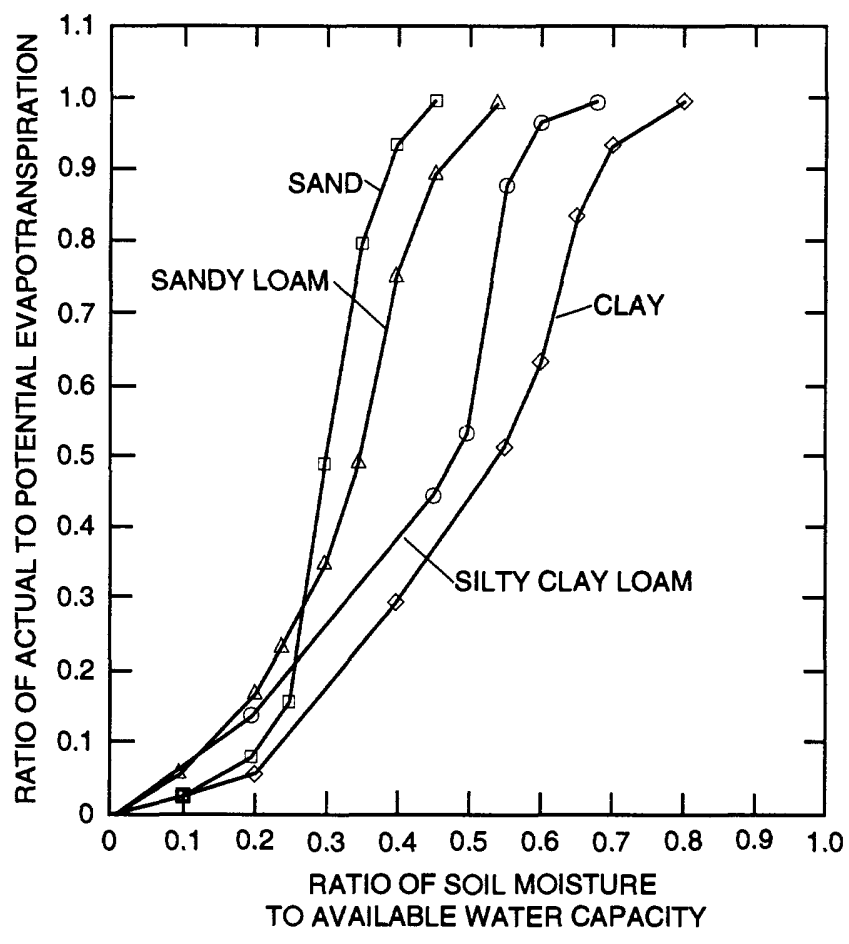

Figure 10. Relation between actual and potential evapotranspiration based on soil type and soil moisture.

estimate annual pan evaporation in water year 1988 (table 11). Snyder and others (1987) estimate of annual reference evapotranspiration for the San Francisco area (35.0 in.) is close to that for pan evaporation at Lake Merced (35.2 in.), but it should be considerably lower. These estimates of evapotranspiration probably do not reflect fully the maritime microclimate of the San Francisco peninsula.

Coastal fog has been shown to cause significant reduction in rates of evapotranspiration (California Department of Water Resources, 1975b; Pruitt and others, 1987). The maximum influence of coastal factors reported by the California Department of Water Resources (1975b) corresponds to a reduction in evapotranspiration of about 35 percent. Areas affected by coastal influences also would tend to have relatively low seasonal fluctuations in evapotranspiration rates. Reference evapotranspiration values calculated using the hydrologic routing model, as described above, show a relatively low total (27.7 in.) and dampened seasonal fluctuation as compared with values from Snyder and others (1987) (table 11). The calculated values are consistent with the expected coastal effects in San Francisco.

Using the 35-percent coastal-reduction factor (California Department of Water Resources, 1975b),
Table 11. Estimated and calculated reference evapotranspiration with pan evaporation from Lake Merced

[Estimated reference evapotranspiration: Data from Snyder and others, 1987. Pan evaporation, Lake Merced: Data from Yates and others, 1990. All values in inches]

\begin{tabular}{|c|c|c|c|}
\hline \multirow{2}{*}{ Month } & \multicolumn{2}{|c|}{$\begin{array}{c}\text { Reference } \\
\text { evapotranspiration }\end{array}$} & \multirow{2}{*}{$\begin{array}{c}\text { Pan } \\
\text { evaporation } \\
\text { Lake } \\
\text { Merced }\end{array}$} \\
\hline & Estimated & Calculated & \\
\hline \multicolumn{4}{|l|}{1987} \\
\hline October & 2.81 & 2.58 & 2.59 \\
\hline November & 1.30 & 1.87 & 1.67 \\
\hline December & .73 & 1.44 & 1.08 \\
\hline \multicolumn{4}{|l|}{1988} \\
\hline January . . . . . & 1.46 & 1.51 & 1.18 \\
\hline February .... & 1.32 & 1.68 & 1.77 \\
\hline March . & 2.44 & 2.25 & 2.80 \\
\hline April & 2.95 & 2.30 & 3.11 \\
\hline May . . . . . . & 3.66 & 2.62 & 4.05 \\
\hline June & 4.61 & 2.80 & 5.06 \\
\hline July & 4.88 & 3.19 & 5.58 \\
\hline August & 4.76 & 2.96 & 3.17 \\
\hline September . . . & 4.13 & 2.47 & 3.17 \\
\hline$\underset{\text { (rounded) }}{\text { Total ... }}$ & 35.0 & 27.7 & 35.2 \\
\hline
\end{tabular}

a range of reference evapotranspiration values can be calculated from previous estimates for comparison with results from the hydrologic routing model. Accordingly, previous estimates of reference evapotranspiration for June, July, and August, which are the highest monthly rates, range from 9.26 to 14.25 in. (Pruitt and others, 1987) and 8.29 to 12.75 in. (California Department of Water Resources, 1975b). The calibrated hydrologic routing model estimates a reference evapotranspiration (in Golden Gate Park) of 8.95 in. for the same time period. This estimate is on the low end of previous estimates, which may be attributed to: (1) a relatively strong coastal influence on evapotranspiration in San Francisco because the city virtually is surrounded by water; and (2) conservation efforts in response to the drought effectively lowered total evapotranspiration.

\section{CALIBRATION AND SENSITIVITY OF HYDROLOGIC ROUTING MODEL}

The hydrologic routing model was calibrated on a monthly basis by comparing simulated and meas- 
ured values of two variables: (1) total municipal water delivered, and (2) sewer flow on the east and west side. The calibration period was from October 1986 through September 1988 (water years 1987-88); however, values from October 1986 through March 1987 are not presented here because of the unavailability of one component of sewer flow data during this period. On completion of the monthly calibration, the hydrologic routing model was modified for use on a storm-by-storm basis for the purpose of testing the robustness of the model and calibrating runoff-related variables. Measured and calculated sewer flow on the east and west sides were compared for each storm.

Indoor and outdoor use of municipal water are calculated in the hydrologic routing model. Indoor use, which is the bulk of municipal water use, is calculated from measured municipal delivery by adjusting for water-pipe leakage and the estimated fraction of indoor water use for a given month. Outdoor use is calculated independent of measured municipal delivery based on irrigation demand. Irrigation demand is derived from estimates of potential evapotranspiration and soil moisture. During calibration, the sum of calculated indoor and outdoor use of municipal water was compared with measured deliveries.

Sewer flow is calculated in the hydrologic routing model based on rainfall runoff, the part of indoor water use that becomes wastewater, and sewer-pipe leakage. Measured values of sewer flow used for comparison during calibration were compiled from measured and estimated values. The estimated part of measured sewer flow is relatively small, so the compiled values are referred to as measured values in this report.

\section{SEWER FLOW}

There are three water-pollution control plants (WPCP) in San Francisco. The Richmond-Sunset WPCP serves about 11,440 acres on the west side of San Francisco, and the North Point and Southeast WPCP's serve a total of about 17,880 acres on the east side. Sewer flow is gaged through each of these plants. For the purpose of this report, data from the two east-side treatment plants were combined, and the east side is treated as a single unit.

The sewer system in San Francisco is a combined system that routes sewage and storm-drain flows through the same pipes. Consequently, sewer flow can vary substantially with changes in weather. During large storms, the capacity of the system can be exceeded and overflows can occur. The problem of system overflow is handled differently on the east and west sides of San Francisco. Sewer flow is about three times greater on the east side than on the west side, and the larger capacity of the sewer system enables the system to operate relatively efficiently with respect to overflow. On the west side, storm runoff can be a much larger percentage of total flow, and the Richmond-Sunset WPCP often cannot handle the increased volume. The Westside Transport System was developed to capture sewer water during storms that would have overflowed. This system consists of underground storage tanks with a combined capacity of about 150 acre-ft, a pumping plant, and an ocean outfall. Sewer water is diverted to the storage tanks during storms, where the relatively solid-free water is decanted off and pumped to the ocean outfall. The concentrated sewage then is pumped to the Richmond-Sunset WPCP for treatment. Water levels in the storage tanks are measured hourly.

Overflow still can occur from the east- and westside sewer systems. East-side overflow is measured, so there is a reliable accounting of the total volume of sewer flow over time. West-side overflow is not measured, but can be estimated using an urban hydrology model developed for use by the San Francisco Clean Water Program. Six storms in water year 1988 were selected for analysis of overflow based on a period of at least 3 days of no rainfall before and after the storm. This criteria allows ample time for the sewer flow to reach equilibrium, and therefore minimizes the potential for overestimation of overflow resulting from transient effects from other storms. Table 12 shows that total rainfall for the six storms ranged from 0.37 to $2.74 \mathrm{in}$,, and simulated overflow ranged from 14 to 419 acre- $\mathrm{ft}$ (Chris A. Phanartzis, Hydroconsult Engineers, written commun., April 1991).

Simulated overflow for the six storms was used to estimate total monthly overflow by assuming that the relation between rainfall and overflow, as defined by the six storms, would hold for all other storms. Figure 11 shows simulated overflow as a function of rainfall for the six storms. The curve shown in figure 11 is reasonably well defined for rainfall amounts less than 1.5 in., and indicates a nonlinear relation between rainfall and overflow, particularly at relatively low values of rainfall (less than 1 in.). Using this curve, overflow was estimated for all storms between April 1987 and September 1988. Aside from the six storms simulated by the San Francisco Clean 
Table 12. Rainfall and simulated overflow for six storms on the west side of San Francisco

[Simulated overflow is from the San Francisco Clean Water Program urban hydrology model (Chris A. Phanartzis, Hydroconsultant Engineers, written commun., April 1991). in., inch; acre-ft, acre-foot]

\begin{tabular}{|c|c|c|}
\hline Storm duration & $\begin{array}{c}\text { Total } \\
\text { rainfall } \\
\text { (in.) }\end{array}$ & $\begin{array}{l}\text { Simulated } \\
\text { overflow } \\
\text { (acre-ft) }\end{array}$ \\
\hline \multicolumn{3}{|l|}{1987} \\
\hline October $27-29$ & 1.20 & 98 \\
\hline December 27-30 & 1.13 & 82 \\
\hline \multicolumn{3}{|l|}{1988} \\
\hline January $2-5$ & 2.74 & 419 \\
\hline January $14-18$ & 1.53 & 152 \\
\hline February 27-March 1 . & .72 & 150 \\
\hline May $5-8 \ldots \ldots \ldots \ldots$ & .37 & 14 \\
\hline
\end{tabular}

Water Program, the remaining storms had less than 1.5 in. of rainfall per storm; therefore, they fell on the relatively well defined part of the curve shown in figure 11 .

Figure 12 shows sewer overflow, the volume pumped to the ocean outfall, and the associated total sewer flow from April 1987 through September 1988 at the Richmond-Sunset WPCP. Ocean outfall data were not available for early 1987 . Figure 12 shows that ocean outfall pumpage and overflow represent a significant percentage of total sewer flow in winter months. Winter sewer flow is about twice that in the spring and summer. On the east side, winter flow is about 35 percent higher than spring and summer flow. The difference between the seasonal variability on the east and west sides is attributed to the relatively large volume of spring and summer sewer flow on the east side, which is related to the population density.

Other sources of sewer flow include bay-water infiltration, ground-water infiltration, and inflow from foundation and other dewatering activities. These processes probably do not occur on the west side because most of the sewer system is above the water table, and there is little or no requirement for dewatering. Bay-water infiltration was estimated to average $346 \mathrm{acre}-\mathrm{ft} / \mathrm{mo}$ for $1990-91$ at the Southeast WPCP by the San Francisco Department of Public Works on the basis of chloride concentrations of sewer water (Karen Kubik, written commun., November 1991). In 1974, bay-water infiltration was

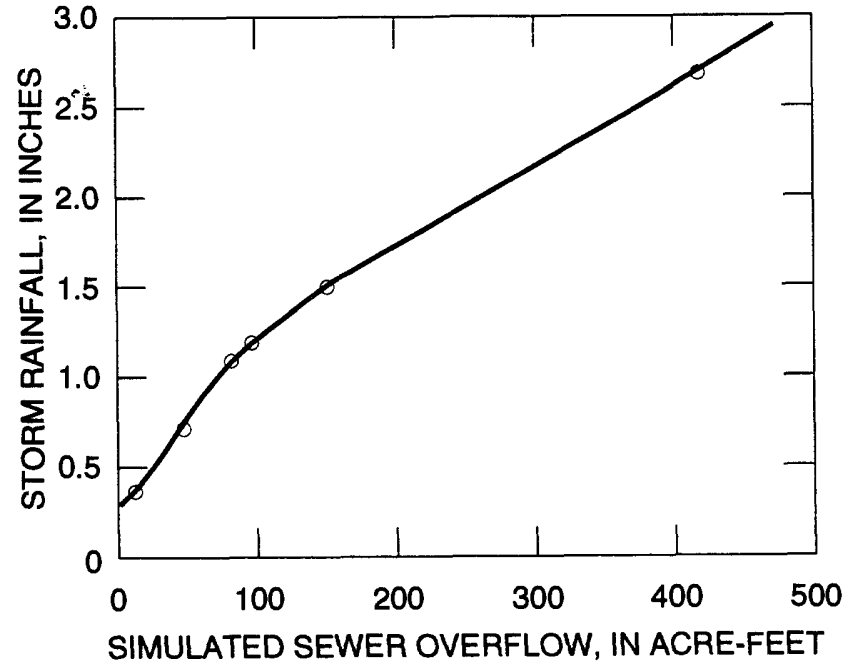

Figure 11. Simulated sewer overflow as a function of rainfall for six storms on the west side of San Francisco in water year 1988. (Chris A. Phanartzis, Hydroconsult Engineers, written commun., April 1991).

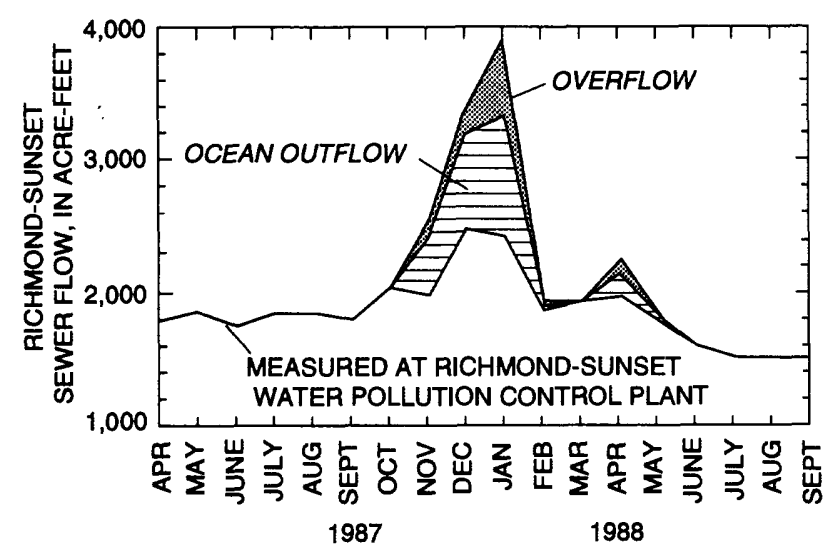

Figure 12. Sewer overflow, sewer water pumped to the ocean outfall, and measured sewer flow at the Richmond-Sunset Water Pollution Control Plant, April 1987-September 1988.

estimated to be 304 acre- $\mathrm{ft} / \mathrm{mo}$ at the Southeast WPCP (San Francisco Department of Public Works, 1974c), and 140 acre-ft/mo at the North Point WPCP (San Francisco Department of Public Works, 1974a). Using the ratio between bay-water infiltration at the two plants during 1974 , the current (1990-91) estimate for the east side is 505 acre- $\mathrm{ft} / \mathrm{mo}$.

Ground-water infiltration to sewers can occur in areas where the sewer pipes are below the water table. It is estimated that about 8 percent of the sewer pipes on the east side are below the water table, but the volume of ground-water infiltration is unknown (San 
Francisco Department of Public Works, 1974a and $1974 \mathrm{c})$. It is possible that ground-water infiltration is highest in areas where sewer pipes intersect buried stream channels. These stream channels, which once were a primary mechanism of discharge, probably still act as high-permeability conduits for ground water.

The relatively high water table on the east side at San Francisco necessitates dewatering operations for building foundations, other underground structures, and construction sites. Some dewatering operations are continuous, and others are intermittent, but most of the ground water pumped is routed to the sewer. The San Francisco Department of Public Works estimates that dewatering operations contribute an average of about 5,600 acre- $\mathrm{ft} / \mathrm{yr}$, which is about 467 acre-ft/mo (Steve Medbery, oral commun., February 1992).

The contribution to sewer flow from bay-water infiltration, ground-water infiltration, and dewatering activities probably is seasonally variable. Infiltration cannot occur, for example, when water pressures in sewer pipes are greater than the surrounding pressure, which probably is common during high-flow periods. It is probable that infiltration is greatest during periods of low rainfall when sewer flow is at a minimum. Because of the unknown seasonal variability and potential inaccuracy of the estimates of bay-water infiltration, ground-water infiltration, and dewatering activities, these estimates were not included in calculated sewer flow. They are discussed qualitatively, however, during comparison of calculated and measured sewer flow.

\section{MONTHLY CALIBRATION}

Calibration of the hydrologic routing model was done by comparing calculated and measured values on a monthly basis of city-wide municipal water delivery and sewer flow for the west and east sides of San Francisco. Early simulations indicated that calculated winter water use closely matched measured values, whereas calculated summer water use was about 10 percent higher than measured. Because calculated winter water use matched measured values, it was assumed that indoor water use was simulated accurately, and that calculated irrigation demand was too high. The effects of water conservation during the drought and overestimation of $E T_{o}$ probably are the primary reasons for the need to reduce calculated summer water use.

Factors that affect irrigation demand include irrigated area, evapotranspiration, soil moisture, irrigation efficiency, and the threshold that initiates irrigation. Soil moisture was assumed to be calculated correctly, and calculated municipal water delivery was relatively insensitive to the irrigation threshold. Irrigated area was reevaluated, and estimates were reduced by 5 or 10 percent in selected land-use zones on the west side, which contains most of irrigated areas in the city. Irrigation efficiency was increased to 70 percent from the initial estimate of 60 percent. Finally, a reasonable match was made between calculated and measured municipal water delivery with a 30-percent decrease in calculated evapotranspiration. Other minor adjustments during calibration included a 15-percent increase in the residential water use intensity factor in selected zones on the west side.

Figure 13 shows calculated and measured municipal water delivered from April 1987 through September 1988. Three of the calculated monthly values significantly depart from the measured curve, whereas the calculated seasonal variations and absolute value of municipal water deliveries generally match the measured values. The greatest departure from the measured curve in May 1987 constitutes an error of less than 8 percent. Although this error is small, it could represent a substantial error in the calculation of outdoor water use. Figure 13 also clearly shows the effects of drought conservation efforts in the summer of 1988.

Calculated and measured sewer flow were compared separately for the west and east sides of the city. Comparisons of calculated and measured sewer flow on the west side indicated that calibration for sewer flow would require minimal changes because

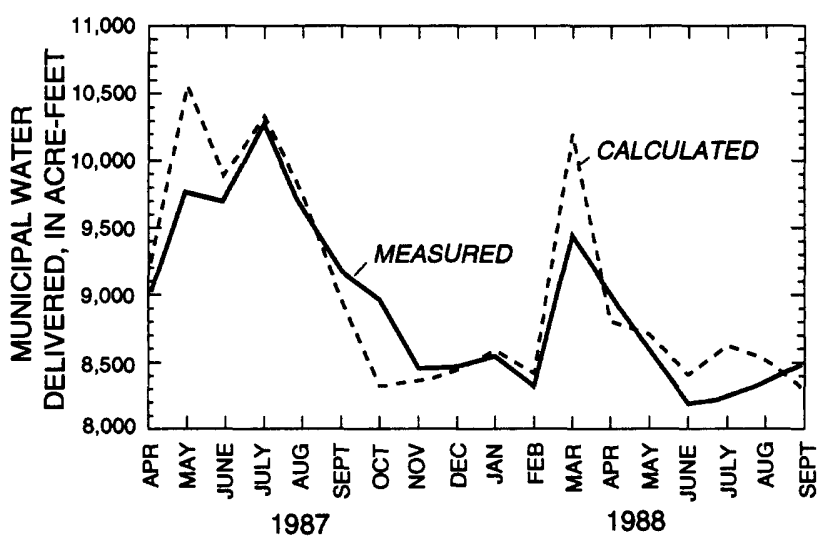

Figure 13. Calculated and measured municipal water delivery in San Francisco, April 1987September 1988. 
they compared well. Calibration for municipal water did not affect sewer flow significantly as irrigation water is a small percentage of municipal delivery, most of which becomes wastewater. The only adjustment during calibration for sewer flow was a 15percent increase in the residential water use intensity factor in selected zones on the west side. Figure $14 A$ shows calculated and measured sewer flow on the west side of San Francisco from April 1987 through September 1988. The curves matched well throughout this time period, and the maximum error in December 1987 was about 6 percent.

Figure $14 B$ shows calculated and measured sewer flow on the east side of San Francisco from April 1987 through June 1988. Calculated values are less than measured values throughout the time period, close to measured values in the winter months, and are least accurate in the summer months. Recall that there are three additional sources of sewer flow on the east side that were not incorporated in the measured values because of unknown seasonal variability and accuracy of the estimated volumes: (1) bay-water infiltration; (2) dewatering activities; and (3) groundwater infiltration.

The results in figure $14 B$ indicate that these additional sources of sewer flow may be seasonally variable, with the highest contribution during lowflow periods (summer), and the lowest during highflow periods (winter). The combined estimated average monthly contribution to sewer flow from baywater infiltration and dewatering activities is 972 acre- $\mathrm{ft} / \mathrm{mo}$. The contribution to sewer flow from ground-water infiltration is unknown, so the estimate of 972 acre- $\mathrm{ft} / \mathrm{mo}$ probably should be considered the minimum average monthly contribution from these three sources. The average monthly difference between calculated and measured sewer flow (fig. $14 B$ ) is about 1,020 acre- $\mathrm{ft}$. This value is consistent with the above estimate of contributions from baywater infiltration and dewatering activities. Uncertainties in the estimates of bay-water infiltration and dewatering activities preclude any conclusions regarding the existence or volume of ground-water inflow.

\section{SIMULATION OF STORMS}

The calibrated hydrologic routing model was tested for robustness by modifying it to simulate individual storms. Storm rainfall and temperature values were calculated as before, using measured daily values. The appropriate monthly values of the fraction of indoor water use and the crop-growth

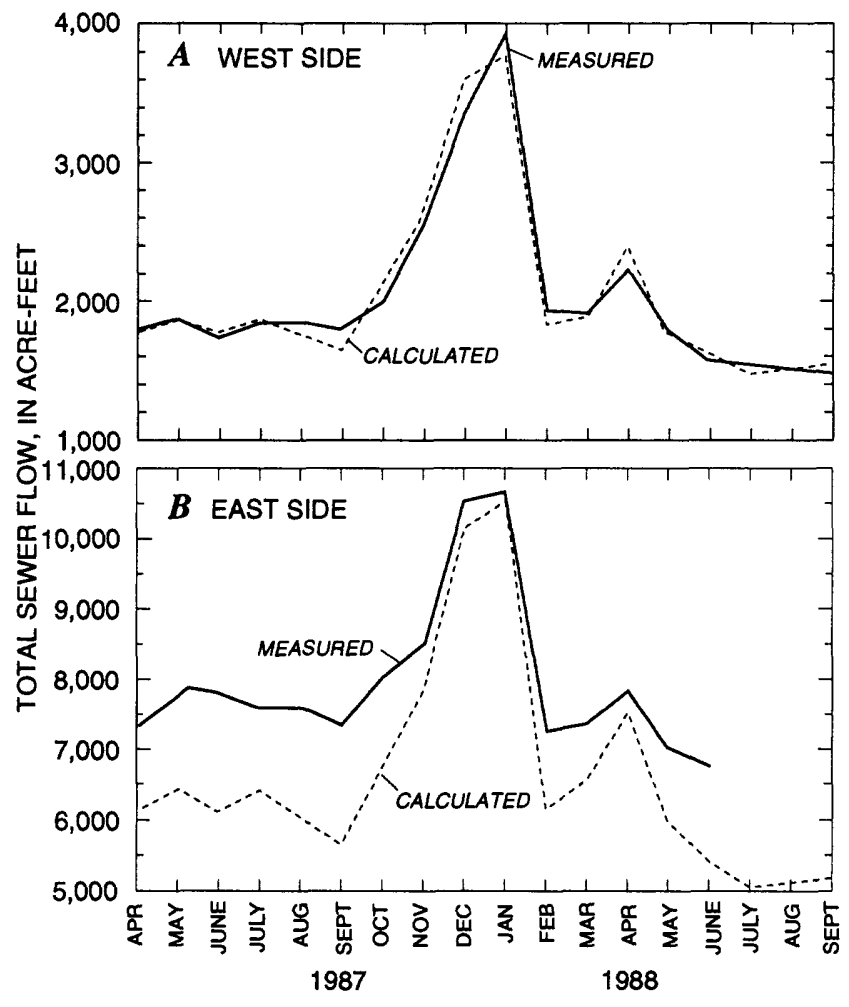

Figure 14. Calculated and measured sewer flow on the west and east sides of San Francisco. April 1987-September 1988. (Note: Scale for west side is twice that of east side).

coefficient $\left(k_{c}\right)$ were used. Monthly municipal water use was prorated for the number of days in a storm, and depression storage was assumed to be 0.06 in. per storm (Overton and Meadows, 1976). It was assumed that irrigation would not occur during a storm. It also was assumed that no runoff from pervious areas occurred, an assumption that could be a substantial source of error for a large storm.

Six storms in water year 1988 when there was no rainfall for several days before or after the storm were selected for simulation. This criterion minimizes possible errors from inclusion of transitory effects from recent storms. Table 13 shows the duration and total rainfall on the west and east sides for the six storms. Total rainfall ranges from 0.37 to 2.74 in. per storm and varies from the east to the west side. On average, the rainfall on the west side was about 13 percent greater than on the east side.

Figure 15 shows the calculated and measured sewer flow for the six storms on the west and east sides of San Francisco. General agreement between calculated and measured values indicates that the hydrologic routing model accurately simulates sewer flow on different temporal scales. 
Table 13. Rainfall for six storms in San Francisco during water year 1988

\begin{tabular}{ccc}
\hline \multirow{2}{*}{ Storm duration } & \multicolumn{2}{c}{ Total rainfall (inches) } \\
\cline { 2 - 3 } & West side & East side \\
\hline 1987 & & \\
October $27-29 \ldots \ldots \ldots \ldots$ & 1.20 & 0.96 \\
December $27-30 \ldots \ldots \ldots \ldots$ & 1.13 & 1.24 \\
1988 & & \\
January $2-5 \ldots \ldots \ldots \ldots$ & 2.74 & 1.75 \\
January $14-18 \ldots \ldots \ldots \ldots$ & 1.53 & 2.06 \\
February $27-$ March $1 \ldots \ldots \ldots$ & .72 & .43 \\
May $5-8 \ldots \ldots \ldots \ldots$ & .37 & .37 \\
\hline
\end{tabular}

\section{SENSITIVITY ANALYSIS AND LIMITATIONS OF THE MODEL.}

Sensitivity analysis is a determination of the sensitivity of simulation results to changes in input variables. The calibration process is an informal sensitivity analysis, whereas a more systematic approach using the calibrated model serves to identify those variables that have the greatest effect on the outcome. The large number of variables used in the hydrologic routing model precludes a complete sensitivity analysis and the consideration of the combined effects of changes in two or more variables.

Variables not addressed formally in the sensitivity analysis include the fraction of indoor water use that becomes wastewater; the fraction of municipal water used indoors; impervious area; pervious nonirrigated area; runoff from pervious areas; initial soil moisture; and the relative water-use intensity factor for indoor use. The California Department of Water Resources (1983) estimate of the fraction of indoor water use that becomes wastewater was assumed to be correctan error in this value would affect calculated sewer flow. The fraction of municipal water used indoors was estimated from water-consumption data from the San Francisco Water Department, and errors would affect calculated sewer flow. Estimates of area probably are accurate to within 10 percent. Adjustments of impervious area would affect sewer flow and the associated change in pervious area would affect municipal delivery and ground-water recharge. The assumption that runoff does not occur from pervious areas may result in an underestimate of sewer flow and an overestimate of ground-water recharge. Initial soil moisture only is used for the first month simulated, so any error in this estimate is minimal for the water-use intensity factor for indoor use would not

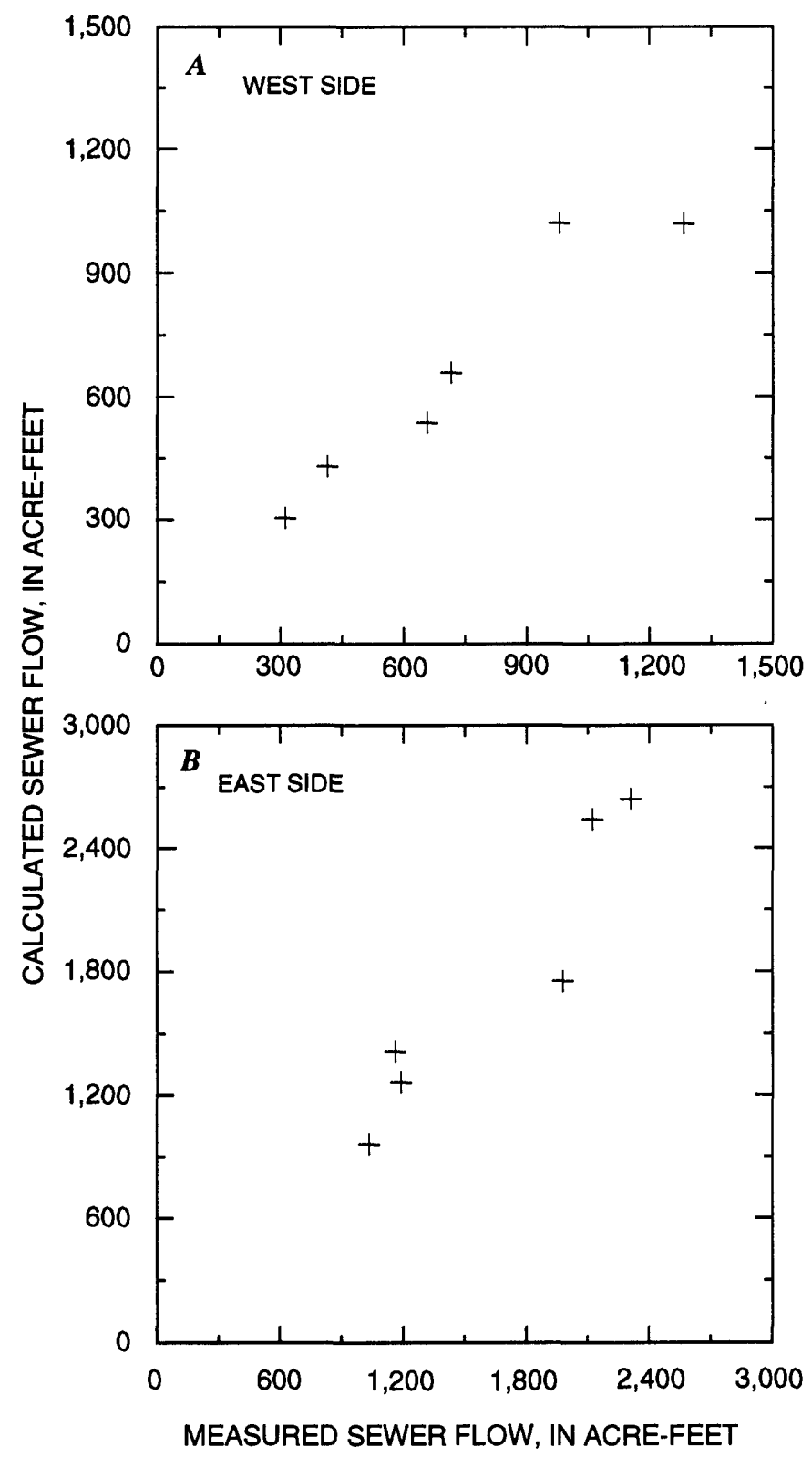

Figure 15. Calculated and measured sewer flow for six storms on the west and east sides of San Francisco, water year 1988.

cause city-wide changes, but could result in substantial changes in sewer flow and ground-water recharge in individual land-use zones.

Table 14 shows the results of the more rigorous sensitivity analysis applied to the remaining variables. Individual variables were altered from the calibrated value while all other variables remained fixed. Variables were changed by 25 percent or more, with the exception of those that are based on accurate measured data, such as rainfall and temperature. The 
Table 14. Results of sensitivity analysis

[acre-ft, acre-foot; in/mo, inch per month; in/in, inch per inch; in/yr, inch per year; ${ }^{\circ} \mathrm{F}$, degree Fahrenheit]

\begin{tabular}{|c|c|c|}
\hline \multirow[t]{2}{*}{ Variable changed } & \multicolumn{2}{|c|}{$\begin{array}{l}\text { Calculated average annual ground-water } \\
\text { recharge for water years } 1987-88 \\
\text { calibrated value }=16,489 \text { acre-ft }\end{array}$} \\
\hline & $\begin{array}{l}\text { New value } \\
\text { (acre-ft) }\end{array}$ & Percentage of change \\
\hline Increased depression storage (DEPR) from 0.2 to $0.25 \mathrm{in} / \mathrm{mo} \quad$. & 16,416 & -0.4 \\
\hline $\begin{array}{l}\text { Increased municipal and sewer pipe leakage rates } \\
\text { (WLKRATE, SLKRATE) from } 4 \text { to } 5 \text { percent }\end{array}$ & 18,636 & 13.0 \\
\hline Increased available water content (AWC) by $0.02 \mathrm{in} / \mathrm{in}$ of soil depth $\ldots \ldots$ & 16,212 & -1.7 \\
\hline Changed all soil types (ICURVE) to sand & 16,597 & .5 \\
\hline Increased the irrigation threshold (ETFIRR) from 0.70 to 0.88 & 16,548 & .4 \\
\hline Increased irrigation efficiency (EFFIC) from 0.70 to 0.88 & 14,770 & -10.4 \\
\hline $\begin{array}{l}\text { Increased reference evapotranspiration mulitplier (ETMULT) } \\
\text { from } 0.70 \text { to } 0.88 \ldots \ldots \ldots \ldots \ldots \ldots \ldots \ldots \ldots\end{array}$ & 16,618 & .8 \\
\hline $\begin{array}{l}\text { Increased fraction of water that leaks or runs off from impervious } \\
\text { to pervious areas (FRIMPLK) by } 0.10 \ldots \ldots \ldots \ldots \ldots\end{array}$ & 18,323 & 11.1 \\
\hline Increased average annual rainfall (RANNL) by $1.0 \mathrm{in} / \mathrm{yr}$. & 16,908 & 2.5 \\
\hline Increased temperature (AVGTEMP) by $2^{\circ} \mathrm{F} \ldots$ & 16,506 & .1 \\
\hline $\begin{array}{l}\text { Increased irrigated area (AREAIRR) by } 4 \text { percent (associated with } \\
4 \text { percent decrease in nonirrigated pervious area) } \ldots \ldots \ldots \ldots\end{array}$ & 17,530 & 6.3 \\
\hline
\end{tabular}

results in table 14 show that ground-water recharge changed by less than 3 percent for 7 of the 11 variables tested. The maximum change was 13 percent.

A 25-percent increase in depression storage resulted in a decrease in ground-water recharge of 0.4 percent. Available water content was increased by an average of about 15 percent, which is equivalent to changing root depth of vegetation by the same percentage, resulting in a decrease in ground-water recharge of 1.7 percent. Sensitivity to soil type was tested by changing the soil type for all land-use zones to sand. This resulted in an increase in ground-water recharge of 0.5 percent. A 25 -percent increase in the irrigation threshold, which initiates irrigation, resulted in a 0.4 -percent increase in ground-water recharge.
Reference evapotranspiration was increased by 25 percent, resulting in a 0.8-percent increase in groundwater recharge. Rainfall values extracted from the rainfall map developed for this study were increased by $1 \mathrm{in} / \mathrm{yr}$ resulting in a 2.5 -percent increase in ground-water recharge. An increase in measured temperature values of $2^{\circ} \mathrm{F}$ resulted in a 0.1 -percent increase in ground-water recharge. Although some estimates of these variables could be inaccurate by more than the amount tested in the sensitivity analysis, the effect of larger errors in these variables on calculated ground-water recharge would be minimal.

Table 14 shows that ground-water recharge is most sensitive to the leakage rates of water and sewer pipes, irrigation efficiency, the fraction of impervious area that allows leakage or runoff to pervious areas, 
and irrigated area. An increase in the leakage rates of water and sewer pipes from 4 to 5 percent resulted in a 13-percent increase in ground-water recharge. The leakage rates of municipal water pipes are measured regularly, whereas sewer-pipe leakage rates are unknown. The assumption that sewer pipes leak at the same rate as municipal water pipes could be erroneous. Water-quality data indicate that sewer pipes leak, but do not provide information concerning the leakage rate. Large leakage rates would result in a significantly larger estimate of ground-water recharge, particularly on the east side where the population density is greatest.

A 25-percent increase in irrigation efficiency resulted in a 10.4-percent decrease in ground-water recharge. Irrigation efficiency was increased from 60 to 70 percent during calibration, which probably is higher than under average (nondrought) conditions. The results from the sensitivity analysis indicate that if the irrigation efficiency decreases to 60 percent after the drought (a decrease of about 14 percent), ground-water recharge might increase by about 6 percent. Errors in irrigation efficiency would have the greatest effect on the west side, which contains about 58 percent of the irrigated area in San Francisco.

The fraction of water that leaks or runs off from impervious to pervious areas is unknown, but was estimated on the basis of an inverse correlation between impervious areas and leakage or runoff to pervious areas. There could be significant error in these estimates. The sensitivity analysis indicates that an increase of 25 percent of the average fraction of leakage or runoff from impervious to pervious areas results in an increase in ground-water recharge of 11.1 percent. The effect of an increase in the fraction of leakage or runoff from impervious to pervious areas would affect ground-water recharge on the east side of the city more than on the west side, because the east side contains about 69 percent of the impervious area in San Francisco.

The fraction of irrigated area was determined by digitizing large-scale aerial photographs and extrapolating the results to similar areas. The accuracy of this method probably is within about 10 percent. For the sensitivity analysis, irrigated area was increased by 4 percent, which is about 25 percent of the areaweighted average. The 4-percent increase in irrigated area resulted in a 6.3-percent increase in ground-water recharge. Changes in irrigated area have the greatest effect on the west side, which contains about 58 percent of the irrigated area in San Francisco.
Limitations of the method used to estimate ground-water recharge are embodied in the assumptions made in the analysis and the time period over which the analysis was done. There are two assumptions that could be associated with relatively large errors in the estimation of ground-water recharge: (1) there is virtually no runoff from pervious areas; (2) sewer-pipe leakage is the same as municipal waterpipe leakage. The analysis was done using data from water years 1987-88, which were the first 2 years of an ongoing drought. The lower rainfall and decreased water use in San Francisco during the calibration period probably resulted in a low estimate of groundwater recharge relative to average conditions.

\section{ESTIMATED GROUND-WATER RECHARGE}

The calibrated hydrologic routing model was used to provide estimates of ground-water recharge for each land-use zone (tables 20 and 21 , at back of report). The results for individual land-use zones were compiled and discretized for the purpose of estimating average annual (water years 1987-88) groundwater recharge over larger areas. Table 15 shows that the estimated annual total ground-water recharge for San Francisco was 16,489 acre-ft, which is equivalent to a linear rate of about $0.56 \mathrm{ft} / \mathrm{yr}$. The areal distribution of ground-water recharge is an important consideration because rates of ground-water recharge vary significantly among ground-water basins (table 15) and land-use zones.

Table 15. Areal distribution of calculated groundwater recharge in San Francisco by ground-water basin, water years $1987-88$

[acre-ft/yr, acre-foot per year; ft/yr, foot per year]

\begin{tabular}{|c|c|c|}
\hline \multirow{2}{*}{ Basin } & \multicolumn{2}{|c|}{$\begin{array}{l}\text { Average calculated ground- } \\
\text { water recharge rate }\end{array}$} \\
\hline & $\begin{array}{c}\text { Value } \\
\text { (acre-ft/yr) }\end{array}$ & $\begin{array}{l}\text { Rate } \\
(\mathrm{ft} / \mathrm{yr})\end{array}$ \\
\hline Westside & 4,846 & 0.51 \\
\hline Lobos . . & 1,570 & .66 \\
\hline Marina & 1,341 & .60 \\
\hline Downtown & 5,931 & .78 \\
\hline Islais Valley & 1,836 & .37 \\
\hline South .... & 696 & .32 \\
\hline Visitacion Valley . . . . . . & 269 & .33 \\
\hline All west side $\ldots \ldots \ldots$ & 6,416 & .54 \\
\hline All east side & 10,073 & .57 \\
\hline All basins & 16,489 & .56 \\
\hline
\end{tabular}


Table 15 shows that the downtown basin has the highest calculated recharge rate of $0.78 \mathrm{ft} / \mathrm{yr}$. This rate is as much as 140 percent greater than the calculated recharge rates for other east-side ground-water basins. The downtown basin contains land-use zones with the greatest population density, which coincides with the greatest water use and associated generation of waste water. Large volumes of municipal water delivery and sewer flow are associated with relatively large volumes of pipe leakage. Land-use zone 122, which is the highest-density downtown area, has little natural recharge because 95 percent of the zone is impervious. Calculated recharge for zone 122, however, is greater than that for any other zone (1.83 $\mathrm{ft} / \mathrm{yr}$ ) because of pipe leakage. Inaccurate estimation of pipe leakage would have a strong effect on calculated ground-water recharge in specific land-use zones and throughout urbanized San Francisco, particularly on the east side. Overall, pipe leakage accounts for about 34 percent of ground-water recharge on the west side, and about 64 percent of that on the eastside. This disparity is evident when comparing the average recharge rate on the west side $(0.54 \mathrm{ft} / \mathrm{yr})$ with that on the east side $(0.57 \mathrm{ft} / \mathrm{yr})$. Another factor that may bias these values is the effect of water conservation, which would be more pronounced on the west side, where the percentage of irrigated area is greatest.

With the exception of the Marina and Downtown basins, all other basins on the east side have groundwater recharge rates that are lower than average. Ground-water recharge rates for the Westside and Lobos basins are within about 10 percent of the citywide average. The average calculated recharge rate for the Westside basin is $0.51 \mathrm{ft} / \mathrm{yr}$, which is just under the average for all basins. This basin is relatively important in terms of potential future development of ground-water resources because it represents the largest ground-water basin in areal and vertical extent, and contains relatively coarse-grained alluvium. The average ground-water recharge rate for the basin represents the maximum long-term yield of the basin. To attain the maximum yield of the basin would require the interception of all ground water discharging to the ocean without inducing seawater intrusion or causing other undesirable consequences, such as the lowering of water levels in Lake Merced. This probably is an unrealistic expectation, so the attainable yield probably would be less than the average ground-water recharge rate.

The only independent estimate of rates of groundwater recharge is from analysis of tritium data collected for this study (Michel and others, 1991).
Tritium is a radioactive isotope of hydrogen that is commonly used to determine the relative age of ground water. Large quantities of tritium were introduced into the environment through atmospheric testing of nuclear weapons from 1952 through the early 1960's (Michel, 1990). Tritium data from Golden Gate Park indicate that the average rate of groundwater recharge probably is greater than $5 \mathrm{in} / \mathrm{yr}$. The hydrologic routing model results indicate a groundwater recharge rate of about $9.1 \mathrm{in} / \mathrm{yr}$ in Golden Gate Park.

\section{SUMMARY AND CONCLUSIONS}

The city of San Francisco is considering further development of its ground-water resources. Geologic and geophysical data were used to describe the lithology and extent of ground-water basins in the city. The west side of the city is separated from the east by a north-south bedrock ridge. Sediments on the west side predominantly are sands, with evidence of discontinuous fine-grained layers as thick as $50 \mathrm{ft}$. On the east side, coarse-grained sediments are similar to those on the west side, but fine-grained sediments are thicker and more continuous and comprise a greater percentage of these sediments. Seven ground-water basins were delineated in San Francisco separated on the basis of bedrock ridges and topographic divides. The vertical extent of ground-water basins was estimated, on the basis of a compilation of previously published maps of bedrock altitude, more recent borehole data, and geophysical data collected for this investigation.

Current (1993) ground-water usage in San Francisco County primarily is for irrigation of parks and golf courses. San Mateo County withdraws ground water for potable use. Pumpage for irrigation of golf courses and other areas near Lake Merced and for potable use in San Mateo County has resulted in a steep downward and southward hydraulic gradient near Lake Merced. Water-level data for Lake Merced indicate a long-term decline in storage beginning before 1976. The rate of decline increased with the onset of an ongoing drought in 1987. Other than the Lake Merced area, there is no evidence of long-term declines in ground-water levels. During the drought, however, water levels in all measured wells have declined at varying rates.

Existing aquifer and laboratory test data were used to describe aquifer characteristics in San Francisco, whereas most of the data pertain to the west side. Horizontal hydraulic conductivities range from 5 to $31 \mathrm{ft} / \mathrm{d}$, and vertical hydraulic conductivities 
range from 0.0018 to $5.1 \mathrm{ft} / \mathrm{d}$. These results indicate that the coarse-grained deposits that control horizontal flow are relatively continuous and that fine-grained deposits that control vertical flow are relatively discontinuous. Tests done on wells completed in the upper $100 \mathrm{ft}$ of sediments indicated storage coefficients of 0.01 and 0.32 , which indicates unconfined conditions. For depths greater than $100 \mathrm{ft}$ (maximum $360 \mathrm{ft}$ ), measured storage coefficients ranged from 0.00024 to 0.0082 , which represented confined or partly confined conditions.

Concentrations of dissolved constituents in local ground water may be affected by irrigation-return flow (fertilizers), leakage from sewer pipes, saltwater contamination, and geologic sources. Elevated levels of nitrates are the most pervasive water-quality problem in San Francisco. Ten of 22 sites sampled in the San Francisco area had nitrate-nitrogen concentrations greater than $10 \mathrm{mg} / \mathrm{L}$. Inconclusive evidence indicates that fertilizers probably are the primary source of nitrate, but sewer sources also are evident. High chloride concentrations were measured in water from several wells, but the source of chloride is unknown. Possible sources of chloride include sewer water, leaking seawater conveyance pipes, connate water, and historic or current seawater intrusion. Water from several wells had concentrations of iron or manganese in excess of drinking-water standards, and the hardness of most samples was high. Use of local ground water for potable purposes may require mixing with municipal water in some areas to meet drinking-water standards.

A hydrologic routing model was developed for estimating ground-water recharge on an areal basis throughout San Francisco. The model takes into account climatic factors, land and water use, leakage from underground pipes, rainfall runoff, evapotranspiration, and other factors associated with an urban environment. Measured sewer flow and municipal water delivery, which also are simulated by the hydrologic routing model, were used to calibrate the model. The calibrated hydrologic routing model was used to estimate ground-water recharge for various land-use zones and the seven ground-water basins on a monthly basis for water years 1987-88, which are drought years. Recharge rates for the ground-water basins ranged from 0.32 to $0.78 \mathrm{ft} / \mathrm{yr}$. The highest recharge rate is associated with the Downtown basin, which is the most densely populated basin in the city. Most recharge in this basin is associated with leakage from water and sewer pipes, though there is a high degree of uncertainty associated with estimated leakage rates of underground pipes.
The Westside basin is the most promising basin in terms of additional ground-water development. It is the largest basin in San Francisco in areal and vertical extent, and is composed primarily of coarsegrained materials. Ground water in the southern part of the Westside basin in San Francisco County presently is being used for local irrigation and for potable use in San Mateo County. Additional development of ground water in the area near Lake Merced would accelerate present declining lake levels. North of the Lake Merced area, however, hydraulic gradients primarily are westward, and discharge primarily flows to the ocean. The volume of discharge flowing to the ocean is estimated best by the volume of groundwater recharge. The volume of recharge calculated by the hydrologic routing model can be considered an estimate of the basins maximum long-term yield. Attaining the maximum yield of the Westside basin would require interception of all discharge flowing to the ocean. It may not be feasible to intercept all discharge flowing to the ocean without inducing seawater intrusion or causing other undesirable effects, so the attainable yield probably is lower than the volume of ground-water recharge.

\section{References Cited}

Applied Consultants, 1991, Report on the Daly City ground-water investigation and model study: Prepared for the city of Daly City, California, July 1991, 153 p.

Baier, J.H., and Rykbost, K.A., 1976, The contribution of fertilizer to the ground water of Long Island: Ground Water, v. 14, no. 6, p. 439-448.

Barber, L.B., Thurman, E.M., Schroeder, M.P., and Le Blanc, D.R., 1988, Long-term fate of organic micro-pollutants in sewage-contaminated ground water: Environmental Science and Technology, v. 22, p. 205-211.

Bartell, M.J., 1913, Report on the underground water supply of San Francisco County: San Francisco Department of Public Works, $157 \mathrm{p}$.

Bauer, H.H., and Vaccaro, J.J., 1987, Documentation of a deep percolation model for estimating ground-water recharge: U.S. Geological Survey Open-File Report 86-536, $180 \mathrm{p}$.

Blaney, H.F., and Criddle, W.D., 1950, Determining water requirements in irrigated areas from climatological and irrigation data: U.S. Department of Agriculture, Soil Conservation Service, Report T., p. 96.

Bonilla, M.G., 1964, Bedrock-surface map of the San Francisco south quadrangle, California: U.S. Geological Survey Miscellaneous Field Studies Map MF-334, scale $1: 31,680$. 
Bonilla, M.G., 1971, Preliminary geologic map of the San Francisco south quadrangle and part of the Hunter's Point quadrangle, California: U.S. Geological Survey Miscellaneous Field Studies Map MF-311, 2 sheets, scale 1:24,000.

Caldwell-Gonzalez-Kennedy-Tudor, 1982, Bayside facilities plan, expanded geotechnical investigation, geotechnical reference report: San Francisco, California, CaldwellGonzalez-Kennedy-Tudor Consulting Engineers, $127 \mathrm{p}$.

California Department of Water Resources, 1958, Seawater intrusion in California: California Department of Water Resources Bulletin 63, $91 \mathrm{p}$.

1975a, California's ground water: California Department of Water Resources Bulletin 118, $135 \mathrm{p}$. 1975b, Vegetative water use in California, 1974: California Department of Water Resources Bulletin 113-3, $104 \mathrm{p}$.

1983, Urban water use in California: California Department of Water Resources Bulletin 166-3, $239 \mathrm{p}$.

Carlson, P.R., and McCulloch, D.S., 1970, Bedrock-surface map of central San Francisco Bay: U.S. Geological Survey Open-File Map, scale 1:15,840.

CH2M-Hill, 1989, Technical memorandum for Oceanside Water Pollution Control Plant groundwater development study: Emeryville, California, CH2M-Hill, Consulting Engineers report to San Francisco Clean Water Program, $35 \mathrm{p}$.

Clifton, H.E., and Hunter, R.E., 1987, The Merced Formation and related beds: A mile-thick succession of Late Cenozoic coastal and shelf deposits in the seacliffs of San Francisco, California: Geological Society of America Centennial Field Guide-- Cordilleran Section, p. 257-262.

Coast Geo-Constructors, Inc., 1987, Pump test results, Southeast Water Pollution Control Plant: Coast GeoConstructors Inc., letter report to the San Francisco Department of Public Works, July 28, 1987, 11 p.

Dames and Moore, 1979, Final report, geotechnical investigation, route selection study, Richmond Transport Service, San Francisco, California: San Francisco, California, Dames and Moore, Consulting Engineers, $57 \mathrm{p}$.

Davis, S.N., 1969, Porosity and permeability of natural materials, in DeWiest, R.J.M., ed., Flow through porous media: New York, Academic Press, p. 53-89.

Denver, J.M., 1989, Effects of agricultural practices and septic-system effluent on the quality of water in the unconfined aquifer in parts of eastern Sussex County, Delaware: Delaware Geological Survey Report of Investigations no. $45,66 \mathrm{p}$.

Dunne, Thomas, and Leopold, L.B., 1978, Water in environmental planning: W.H. Freeman and Company, San Francisco, California, 818 p.

Flipse, W.J., Jr., Katz, B.G., Lindner, J.B., and Markel, R., 1984, Sources of nitrate in ground water in a sewered housing development, central Long Island, New York: Ground Water, v. 22 , no. 4 , p. 418-426.
Freeze, R.A., and Cherry, J.A, 1979, Groundwater: Englewood Cliffs, New Jersey, Prentice Hall, 604 p.

Hamlin, S.N., and Yates, E.B., 1990, Relations of nitrate concentration and ground-water movement through a water-table lake in San Francisco, California: Ground Water, v. 28, no. 5, p. 794.

Harding-Lawson Associates, 1976a, Geotechnical investigation, west side transport project, pump station and force mains: San Francisco, California, report prepared for Kennedy Engineers, Inc., 106 p.

1976b, West side transport soil investigation, phase

1: San Francisco, California, prepared for San Francisco Department of Public Works, April 1976, 113 p. 1977, Westside transport, geotechnical investigation, pump station at Fleishhacker Pool near Sloat Boulevard: San Francisco, California, report prepared for Kennedy Engineers, Inc., $66 \mathrm{p}$.

Heath, R.C., 1987, Basic ground-water hydrology: U.S. Geological Survey Water-Supply Paper 2220, 84 p.

Hem, J.D., 1985, Study and interpretation of the chemical characteristics of natural water: U.S. Geological Survey Water-Supply Paper 2254, 263 p.

International Atomic Energy Agency, 1981, Statistical treatment of environmental isotopic data in precipitation: International Atomic Energy Agency Technical Report Series no. 206, 255 p.

1983, Guidebook on nuclear techniques in hydrology: International Atomic Energy Agency Technical Report Series no. 91,439 p.

Katz, B.G., Lindner, J.B., and Ragone, S.E., 1980, A comparison of nitrogen in shallow ground water from sewered and unsewered areas, Nassau County, New York, from 1952 through 1976: Ground Water, v. 18, no. 6, p. 607-616.

Kibler, D.F., ed., 1962, Urban storm water hydrology: Water Resources Monograph 7, American Geophysical Union, Washington, D.C., p. 71-72.

Kimmel, G.E., 1972, Nitrogen content of ground water in Kings County, Long Island, New York: U.S. Geological Survey Professional Paper 800-D, p. D199-D203.

Le Blanc, D.R., ed., 1984, Movement and fate of solutes in a plume of sewage-contaminated ground water, Cape Cod, Massachusetts: U.S. Geological Survey Open-File Report 84-475, 180 p.

Lerner, D.N., 1986, Leaking pipes recharge ground water: Journal of Ground Water, v. 24, no. 5, p. 654-662.

Metcalf and Eddy, 1980, Southwest water pollution control plant project, final project report: Palo Alto, California, Metcalf and Eddy Engineers, 73 p.

Michel, R.L., 1990, Tritium deposition in the continental United States, 1953-1983: U.S. Geological Survey Water-Resources Investigations Report 89-4072, $46 \mathrm{p}$.

Michel, R.L., Hamlin, S.N., and Phillips, S.P., 1991, Tritium distributions and recharge to ground water in western San Francisco, California: Eos Transactions of the American Geophysical Union, Abstracts, v. 72, no. 44, p. 206. 
Miller, D.W., 1980, Waste disposal effects on ground water: Berkeley, California, Premier Press, 512 p.

Overton, D.E., and Meadows, M.E., 1976, Stormwater modeling: New York, Academic Press, p. 21-22.

Piper, A.M., Garrett, A.A., and others, 1953, Native and contaminated ground waters in the Long Beach-Santa Ana area, California: U.S. Geological Survey Water-Supply Paper 1136, 320 p.

Pitometer Associates, 1987, Report on pitometer waterwaste survey, San Francisco, California, 1986-1987: Montclair, New Jersey, Pitometer Associates, Engineers, $30 \mathrm{p}$.

Porter, K.S., 1980, An evaluation of sources of nitrogen as causes of ground-water contamination in Nassau County, Long Island: Ground Water, v. 18, no. 6, p. 617-625.

Pruitt, W.O., Fereres, E., Kuita, K., and Snyder, R.L., 1987, Reference evapotranspiration $\left(E T_{0}\right)$ for California: Berkeley, California, University of California, Division of Agriculture and Natural Resources, Bulletin 1922, 11 p.

Roberts, C.W., 1991, Principle facts for more than 700 gravity stations in the San Francisco North and San Francisco South quadrangles, California: U.S. Geological Survey Open-File Report 91-103, 31 p.

San Francisco Department of Public Works, 1974a, Sewer system evaluation for infiltration inflow, North Point District: San Francisco Department of Public Works, $190 \mathrm{p}$.

1974b, Sewer system evaluation for infiltration inflow, Phase 1, Richmond-Sunset District: San Francisco Department of Public Works, 45 p. $1974 c$, Sewer system evaluation for infiltration inflow, Southeast District: San Francisco Department of Public Works, $51 \mathrm{p}$.

1975, Infiltration/inflow, North Point Region Review: San Francisco Water Department, Division of Sanitary Engineering inter-office memo, January 14, 1975, $9 \mathrm{p}$.
Schlocker, Julius, 1974, Geology of the San Francisco north quadrangle, California: U.S. Geological Survey Professional Paper 782, $109 \mathrm{p}$.

Snyder, R.L., Pruitt, W.O., and Shaw, D.A., 1987, Determining daily reference evapotranspiration $\left(\mathrm{ET}_{0}\right)$ : Davis, University of California Cooperative Extension, Division of Agriculture and Natural Resources, Leaflet 21426, 12 p.

Todd, D.K., 1980, Groundwater hydrology: New York, John Wiley, $535 \mathrm{p}$.

U.S. Department of Agriculture, Soil Conservation Service, 1970, Irrigation water requirements: Technical Release No. 21, 88 p.

U.S. Environmental Protection Agency, 1986, Quality criteria for water, 1986, EPA 4405-85-001, 452 p.

Wood, W.W., 1976, Guidelines for collection and field analysis of ground-water samples for selected unstable constituents: U.S. Geological Survey Techniques of Water-Resources Investigations, Book 1 , ch. D2, 24 p.

Woodward-Clyde Consultants, 1977 , Onshore 500-ft boring (boring No. 1), sub-task 2-2, Southwest Ocean Outfall Project: San Francisco, California: Woodward-Clyde Consultants, Basic data report to PBQ\&D Inc., 26 p. 1980, Pump test and infiltration test, Southwest Water Pollution Control Plant Project: San Francisco, California: Woodward-Clyde Consultants, Geotechnical report to PBQ\&D Inc., $8 \mathrm{p}$.

1985, Report on final inspection and testing of Alvord Lake irrigation well, Golden Gate Park, San Francisco, California: Walnut Creek, California, Woodward-Clyde Consultants letter report to San Francisco Department of Public Works, October 25, 1985, 4 p.

Yates, E.B., Hamlin, S.N., and McCann, L.H., 1990, Geohydrology, water quality, and water budgets of Golden Gate Park and the Lake Merced area in the western part of San Francisco, California: U.S. Geological Survey Water-Resources Investigations Report 90-4080, $45 \mathrm{p}$. 
Table 16. Water-level and construction data for wells in San Francisco and part of San Mateo Counties

[Water-level altitude and measuring point in feet above or below (-) sea level. Depth of well in feet below land surface. Well name: HLA, Harding-Lawson Associates. D, deep; M, medium; S, shallow. Locations shown on pl. 2A]

\begin{tabular}{|c|c|c|c|c|c|c|c|}
\hline Date & $\begin{array}{l}\text { Water-level } \\
\text { altitude }\end{array}$ & Date & $\begin{array}{l}\text { Water-level } \\
\text { altitude }\end{array}$ & Date & $\begin{array}{l}\text { Water-level } \\
\text { altitude }\end{array}$ & Date & $\begin{array}{l}\text { Water-level } \\
\text { altitude }\end{array}$ \\
\hline
\end{tabular}

Map No. 2. Phelan Building 2S/5W-3M1. Depth of well: 102.5 feet. Measuring point: 25.55 feet.

\begin{tabular}{rrrrrrrr}
\hline $10-20-88$ & -5.90 & $10-26-89$ & -6.41 & $8-01-90$ & -7.87 & $5-01-91$ & -6.70 \\
$11-18-88$ & -5.84 & $2-06-90$ & -6.74 & $11-06-90$ & -8.10 & $9-17-91$ & -5.50 \\
$3-16-89$ & 2.20 & $5-01-90$ & -7.19 & $2-05-91$ & -7.28 & $2-04-92$ & -5.62 \\
\hline
\end{tabular}

Map No. 4. St. Anne's Home 2S/5W-6M1. Depth of well: 80 feet. Measuring point: 195.13 feet.

\begin{tabular}{rrrrrrrr}
\hline $10-17-88$ & 146.98 & $10-26-89$ & 144.10 & $8-02-90$ & 143.19 & $5-02-91$ & 145.21 \\
$11-18-88$ & 148.51 & $2-06-90$ & 146.96 & $11-07-90$ & 140.63 & $9-18-91$ & 141.48 \\
$3-16-89$ & 150.57 & $5-03-90$ & 145.01 & $2-06-91$ & 145.49 & $2-05-92$ & 143.24 \\
\hline
\end{tabular}

Map No. 5. Alvord Park and Recreation No. 2 2S/5W-7P1. Depth of well: 249 feet. Measuring point: 273.47 feet. Top and bottom of open interval 110-224 feet.

\begin{tabular}{rlrlrlrl}
\hline $8-11-82$ & 222.4 & $8-15-88$ & 216.31 & $9-19-89$ & 215.24 & $8-02-90$ & 210.97 \\
$8-18-82$ & 222.4 & $9-26-88$ & 208.01 & $10-25-89$ & 213.98 & $9-05-90$ & 212.18 \\
$12-10-87$ & 193.27 & $11-15-88$ & 209.67 & $11-21-89$ & 214.05 & $10-10-90$ & 213.95 \\
$1-23-88$ & 182.26 & $1-04-89$ & 210.38 & $12-06-89$ & 209.98 & $11-06-90$ & 216.05 \\
$2-27-88$ & 207.19 & $2-07-89$ & 207.41 & $2-06-90$ & 208.37 & $12-04-90$ & 216.57 \\
$3-28-88$ & 191.73 & $3-14-89$ & 202.44 & $3-06-90$ & 216.57 & $2-05-91$ & 217.01 \\
$4-20-88$ & 199.72 & $4-24-89$ & 185.34 & $4-05-90$ & 210.42 & $5-03-91$ & 214.89 \\
$5-18-88$ & 209.82 & $6-01-89$ & 198.97 & $5-01-90$ & 205.26 & $9-17-91$ & 216.07 \\
$6-14-88$ & 210.47 & $7-07-89$ & 187.41 & $6-05-90$ & 207.74 & $2-05-92$ & 214.80 \\
$7-19-88$ & 213.97 & $8-16-89$ & 196.15 & $7-02-90$ & 207.08 & & \\
\hline
\end{tabular}

Map No. 6. Davies Hospital 2S/5W-8P1. Depth of well: 230 feet. Measuring point: 200.56 feet. Top and bottom of open interval 130-210 feet.

\begin{tabular}{rrrrrrrr}
\hline $10-27-88$ & 174.56 & $10-26-89$ & 173.25 & $8-01-90$ & 174.12 & $5-01-91$ & 173.98 \\
$11-15-88$ & 174.44 & $2-06-90$ & 173.16 & $11-06-90$ & 173.86 & $9-17-91$ & 173.71 \\
$3-16-89$ & 174.80 & $5-01-90$ & 174.23 & $2-05-91$ & 173.71 & $2-04-92$ & 173.91 \\
\hline
\end{tabular}

Map No. 7. International Center 2S/5W-9F1. Depth of well: 107 feet. Measuring point: 35.23 feet.

\begin{tabular}{rrrrrrrr}
\hline $10-19-88$ & 31.23 & $10-26-89$ & 29.65 & $8-01-90$ & 29.44 & $5-01-91$ & 28.85 \\
$11-18-88$ & 30.76 & $2-06-90$ & 28.98 & $11-06-90$ & 29.15 & $9-17-91$ & 28.89 \\
$3-16-89$ & 30.49 & $5-01-90$ & 29.38 & $2-05-91$ & 28.20 & $2-04-92$ & 28.45 \\
\hline
\end{tabular}

Map No. 8. French Laundry 2S/5W-16E1. Depth of well: 94 feet. Measuring point: 33.32 feet.

\begin{tabular}{|c|c|c|c|c|c|c|c|}
\hline $10-18-88$ & 26.32 & $10-26-89$ & 26.11 & $8-01-90$ & 25.79 & $5-01-91$ & 26.32 \\
\hline $11-18-88$ & 25.63 & $2-06-90$ & 26.05 & $11-06-90$ & 26.07 & $9-17-91$ & 26.11 \\
\hline $3-16-89$ & 26.25 & $5-01-90$ & 25.88 & $2-05-91$ & 25.94 & 2-04-92 & 25.89 \\
\hline
\end{tabular}

Map No. 9. St. Paul's 2S/5W-20J1. Depth of well: 42 feet. Measuring point: 133.61 feet.

\begin{tabular}{rrrrrrrr}
\hline $10-19-88$ & 109.71 & $2-07-90$ & 116.23 & $11-06-90$ & 115.31 & $9-17-91$ & 115.48 \\
$3-16-89$ & 116.87 & $5-01-90$ & 116.38 & $2-05-91$ & 114.89 & $2-04-92$ & 115.25 \\
$10-26-89$ & 116.12 & $8-01-90$ & 116.60 & $5-01-91$ & 116.06 & &
\end{tabular}


Table 16. Water-level and construction data for wells in San Francisco and part of San Mateo Counties--Continued

\begin{tabular}{|c|c|c|c|c|c|c|c|}
\hline Date & $\begin{array}{l}\text { Water-level } \\
\text { altitude }\end{array}$ & Date & $\begin{array}{l}\text { Water-level } \\
\text { altitude }\end{array}$ & Date & $\begin{array}{l}\text { Water-level } \\
\text { altitude }\end{array}$ & Date & $\begin{array}{l}\text { Water-level } \\
\text { altitude }\end{array}$ \\
\hline
\end{tabular}

Map No. 10. AC Electric 2S/5W-27L1. Depth of well: 100 feet. Measuring point: 29.78 feet. Top and bottom of open interval 23-89 feet.

\begin{tabular}{rrrrrrrr}
\hline $10-20-88$ & 26.23 & $2-07-90$ & 26.19 & $9-05-90$ & 25.62 & $5-01-91$ & 26.03 \\
$3-20-89$ & 26.11 & $5-01-90$ & 26.24 & $11-06-90$ & 25.46 & $9-17-91$ & 25.63 \\
$5-16-89$ & 27.13 & $6-05-90$ & 26.23 & $2-05-91$ & 25.42 & $2-04-92$ & 25.56 \\
$10-27-89$ & 26.23 & & & & & & \\
\hline
\end{tabular}

Map No. 11. Brussels Street 2S/5W-27N1. Depth of well: 20 feet. Measuring point: 70.16 feet.

\begin{tabular}{rrrrrrrr}
\hline $10-18-88$ & 60.62 & $10-27-89$ & 61.01 & $8-01-90$ & 60.66 & $5-01-91$ & 60.23 \\
$3-16-89$ & 62.33 & $2-07-90$ & 61.41 & $11-06-90$ & 60.03 & $9-17-91$ & 60.18 \\
$5-16-89$ & 61.81 & $4-03-90$ & 61.35 & $2-05-91$ & 60.27 & $2-04-92$ & 60.28 \\
\hline
\end{tabular}

Map No. 12. Herz Playground 2S/5W-33L1. Depth of well: 81 feet. Measuring point: 120.86 feet. Top and bottom of open interval 65.75-75.75 feet.

\begin{tabular}{rrrrrrrr}
\hline $7-07-89$ & 70.39 & $10-27-89$ & 69.26 & $6-05-90$ & 67.26 & $1-08-91$ & 65.12 \\
$8-16-89$ & 70.12 & $11-22-89$ & 69.03 & $7-02-90$ & 66.84 & $2-05-91$ & 64.77 \\
$9-20-89$ & 69.59 & $12-07-89$ & 68.95 & $8-01-90$ & 66.64 & $5-01-91$ & 63.99 \\
$10-17-89$ & 69.28 & $2-07-90$ & 68.19 & $9-05-90$ & 66.20 & $9-17-91$ & 62.69 \\
$10-18-89$ & 69.40 & $3-07-90$ & 68.16 & $10-10-90$ & 65.98 & $2-04-92$ & 61.40 \\
$10-19-89$ & 69.40 & $4-02-90$ & 67.69 & $11-06-90$ & 65.73 & & \\
\hline
\end{tabular}

Map No. 13. Presidio 319 2S/6W-1K1. Depth of well: 90 feet. Measuring point: 136.31 feet.

\begin{tabular}{rrrrrrrr}
\hline $11-15-88$ & 132.28 & $2-06-90$ & 133.87 & $11-07-90$ & 127.28 & $9-18-91$ & 129.84 \\
$3-20-89$ & 134.75 & $5-02-90$ & 126.19 & $2-06-91$ & 132.76 & $2-05-92$ & 130.68 \\
$10-26-89$ & 132.63 & $8-02-90$ & 126.35 & $5-02-91$ & 127.41 & & \\
\hline
\end{tabular}

Map No. 14. Presidio 6 2S/6W-2H1. Depth of well: 60 feet. Measuring point: 24.46 feet.

\begin{tabular}{rrrrrrrr}
\hline $11-15-88$ & 17.98 & $4-24-89$ & 18.10 & $2-06-90$ & 18.56 & $2-06-91$ & 18.02 \\
$12-05-88$ & 18.05 & $7-06-89$ & 10.21 & $3-06-90$ & 17.81 & $5-02-91$ & 17.96 \\
$1-04-89$ & 18.37 & $10-24-89$ & 17.14 & $4-05-90$ & 17.90 & $9-19-91$ & 17.66 \\
$2-07-89$ & 18.15 & $11-20-89$ & 17.87 & $6-01-90$ & 17.63 & $2-05-92$ & 18.50 \\
$3-14-89$ & 18.14 & $12-06-89$ & 18.14 & $1-10-91$ & 17.50 & & \\
\hline
\end{tabular}

Map No. 15. Windmill Northeast 2S/6W-10L1. Depth of well: 156 feet. Measuring point: 33.19 feet.

\begin{tabular}{rrrrrrrr}
\hline $12-10-87$ & 16.97 & $1-04-89$ & 15.57 & $11-21-89$ & 14.72 & $10-11-90$ & 13.00 \\
$1-15-88$ & 16.12 & $2-07-89$ & 15.05 & $12-07-89$ & 14.62 & $11-07-90$ & 14.00 \\
$2-27-88$ & 15.63 & $3-14-89$ & 15.02 & $2-06-90$ & 13.67 & $12-04-90$ & 13.96 \\
$3-28-88$ & 16.19 & $6-01-89$ & 13.09 & $3-06-90$ & 14.13 & $2-06-91$ & 13.66 \\
$4-20-88$ & 15.98 & $7-07-89$ & 14.86 & $4-04-90$ & 14.73 & $5-01-90$ & 14.21 \\
$5-18-88$ & 7.59 & $8-16-89$ & 14.42 & $5-01-90$ & 10.36 & $9-19-91$ & 10.86 \\
$8-15-88$ & 15.59 & $9-19-89$ & 15.03 & $6-06-90$ & 11.86 & $2-05-92$ & 12.51 \\
$8-16-88$ & 14.79 & $10-21-89$ & 14.72 & $7-03-90$ & 11.77 & & \\
$11-09-88$ & 15.67 & $10-25-89$ & 15.30 & $9-06-90$ & 12.81 & &
\end{tabular}


Table 16. Water-level and construction data for wells in San Francisco and part of San Mateo Counties--Continued

\begin{tabular}{lccccccc}
\hline \multicolumn{1}{l}{ Date } & $\begin{array}{c}\text { Water-level } \\
\text { altitude }\end{array}$ & Date & $\begin{array}{c}\text { Water-level } \\
\text { altitude }\end{array}$ & Date & $\begin{array}{c}\text { Water-level } \\
\text { altitude }\end{array}$ & Date & $\begin{array}{c}\text { Water-level } \\
\text { altitude }\end{array}$ \\
\hline Map No. 16. Windmill Northwest 2S/6W-10L2. & Depth of well: 281 feet. & Measuring point: 44.76 feet. & \\
\hline $12-10-87$ & 18.91 & $9-19-89$ & 16.79 & $4-04-90$ & 16.66 & $11-07-90$ & 15.67 \\
$1-04-89$ & 17.37 & $10-25-89$ & 16.98 & $5-01-90$ & 11.52 & $12-04-90$ & 15.55 \\
$2-07-89$ & 17.18 & $11-21-89$ & 16.31 & $7-03-90$ & 12.99 & $2-06-91$ & 14.90 \\
$3-14-89$ & 16.83 & $12-07-89$ & 16.47 & $8-02-90$ & 14.64 & $5-01-91$ & 15.88 \\
$6-01-89$ & 14.49 & $2-06-90$ & 15.56 & $9-06-90$ & 14.30 & $9-19-91$ & 11.80 \\
$7-07-89$ & 16.64 & $3-06-90$ & 16.14 & $10-10-90$ & 14.35 & $2-05-92$ & 13.66 \\
$8-16-89$ & 16.29 & & & & & & \\
\hline
\end{tabular}

Map No. 17. Elk Glen-D 2S/6W-11R1. Depth of well: 360 feet. Measuring point: 169.12 feet. Top and bottom of open interval 170-350 feet.

\begin{tabular}{rrrrrrrr}
\hline $10-02-87$ & 100.10 & $8-15-88$ & 112.78 & $9-19-89$ & 111.96 & $8-02-90$ & 110.33 \\
$12-20-87$ & 123.30 & $11-09-88$ & 116.22 & $10-25-89$ & 112.93 & $9-05-90$ & 110.34 \\
$1-15-88$ & 125.20 & $1-04-89$ & 104.44 & $11-20-89$ & 105.23 & $10-10-90$ & 111.26 \\
$2-27-88$ & 112.22 & $2-07-89$ & 92.27 & $12-06-89$ & 105.39 & $11-07-90$ & 111.13 \\
$3-28-88$ & 117.93 & $3-14-89$ & 116.06 & $2-06-90$ & 118.84 & $12-05-90$ & 112.28 \\
$4-20-88$ & 116.49 & $4-24-89$ & 108.75 & $3-07-90$ & 117.59 & $2-07-91$ & 110.95 \\
$5-18-88$ & 118.28 & $6-01-89$ & 99.83 & $4-04-90$ & 115.71 & $5-02-91$ & 113.64 \\
$6-14-88$ & 103.95 & $7-06-89$ & 99.12 & $5-02-90$ & 115.20 & $9-17-91$ & 120.54 \\
$7-19-88$ & 114.12 & $8-16-89$ & 106.89 & $6-06-90$ & 115.32 & $2-04-92$ & 119.10 \\
\hline
\end{tabular}

Map No. 18. Elk Glen-S 2S/6W-11R2. Depth of well: 72 feet. Measuring point: 173.34 feet. Top and bottom of open interval 58-68 feet.

\begin{tabular}{rrrrrrrr}
\hline $7-06-89$ & 130.38 & $2-06-90$ & 131.01 & $8-02-90$ & 128.64 & $1-10-91$ & 127.76 \\
$8-16-89$ & 131.81 & $3-07-90$ & 129.82 & $9-05-90$ & 128.34 & $2-07-91$ & 127.18 \\
$9-19-89$ & 130.49 & $4-04-90$ & 130.38 & $10-10-90$ & 128.31 & $5-02-91$ & 127.34 \\
$10-25-89$ & 130.40 & $5-02-90$ & 130.12 & $11-07-90$ & 127.83 & $9-17-91$ & 129.70 \\
$11-20-89$ & 130.45 & $6-06-90$ & 129.94 & $12-05-90$ & 127.94 & $2-04-92$ & 128.99 \\
$12-06-89$ & 130.31 & $8-02-90$ & 128.55 & & & & \\
\hline
\end{tabular}

Map No. 19. French Hospital 2S/6W-12A1. Depth of well: 100 feet. Measuring point: 185.67 feet.

\begin{tabular}{rrrrrrrr}
\hline $10-19-88$ & 152.42 & $10-19-88$ & 150.54 & $4-03-90$ & 149.73 & $2-06-91$ & 147.96 \\
$11-18-88$ & 152.31 & $10-20-89$ & 150.54 & $5-02-90$ & 149.51 & $5-02-91$ & 147.59 \\
$3-16-89$ & 151.66 & $10-26-89$ & 150.59 & $8-02-90$ & 149.00 & $9-17-91$ & 146.84 \\
$5-18-89$ & 151.27 & $2-06-90$ & 150.04 & $11-07-90$ & 148.52 & $2-05-92$ & 146.08 \\
$10-18-89$ & 150.58 & & & & & & \\
\hline
\end{tabular}

Map No. 20. Arboretum 4 2S/6W-12Q1. Depth of well: 250 feet. Measuring point: 206.99 feet.

\begin{tabular}{rrrrrrrr}
\hline $10-02-87$ & 129.00 & $11-15-88$ & 168.23 & $10-25-89$ & 166.84 & $8-02-90$ & 163.59 \\
$12-10-87$ & 171.12 & $1-04-89$ & 169.31 & $11-21-89$ & 166.00 & $9-06-90$ & 163.60 \\
$1-15-88$ & 171.77 & $2-07-89$ & 169.40 & $12-06-89$ & 167.29 & $10-11-90$ & 163.72 \\
$2-27-88$ & 171.16 & $3-14-89$ & 169.64 & $2-06-90$ & 167.61 & $12-04-90$ & 164.50 \\
$3-28-88$ & 171.44 & $4-24-89$ & 169.20 & $4-05-90$ & 166.24 & $2-05-90$ & 164.63 \\
$4-20-88$ & 170.92 & $6-01-89$ & 166.52 & $5-02-90$ & 165.69 & $5-03-91$ & 164.02 \\
$5-18-88$ & 171.44 & $8-16-89$ & 165.26 & $6-06-90$ & 165.17 & $9-18-91$ & 162.97 \\
$8-17-88$ & 167.16 & $9-19-89$ & 166.81 & $7-03-90$ & 164.18 & $2-05-92$ & 163.46
\end{tabular}


Table 16. Water-level and construction data for wells in San Francisco and part of San Mateo Counties--Continued

\begin{tabular}{|c|c|c|c|c|c|c|c|}
\hline Date & $\begin{array}{l}\text { Water-level } \\
\text { altitude }\end{array}$ & Date & $\begin{array}{l}\text { Water-level } \\
\text { altitude }\end{array}$ & Date & $\begin{array}{l}\text { Water-level } \\
\text { altitude }\end{array}$ & Date & $\begin{array}{l}\text { Water-level } \\
\text { altitude }\end{array}$ \\
\hline
\end{tabular}

Map No. 21. Arboretum 5 2S/6W-12Q2. Depth of well: 250 feet. Measuring point: 207.67 feet.

\begin{tabular}{llllllll}
\hline $10-02-87$ & 161.67 & $12-06-89$ & 173.05 & $2-06-90$ & 172.92 & $3-06-90$ & 172.94 \\
$12-10-87$ & 176.76 & & & & & & \\
\hline
\end{tabular}

Map No. 22. HLA B 2S/6W-15C1. Depth of well: 65 feet. Measuring point: 19.77 feet.

\begin{tabular}{rrrrrrrr}
\hline $10-14-87$ & 9.94 & $4-20-88$ & 10.67 & $6-16-89$ & 10.35 & $11-07-90$ & 10.11 \\
$11-18-87$ & 11.11 & $5-13-88$ & 9.15 & $10-27-89$ & 10.65 & $2-06-91$ & 10.11 \\
$12-10-87$ & 11.60 & $6-14-88$ & 9.74 & $2-07-90$ & 10.84 & $5-02-91$ & 9.96 \\
$1-15-88$ & 11.43 & $7-17-88$ & 9.57 & $5-02-90$ & 8.45 & $9-18-91$ & 6.68 \\
$2-24-88$ & 10.78 & $8-15-88$ & 9.80 & $8-02-90$ & 10.05 & $2-05-92$ & 10.08 \\
$3-28-88$ & 10.59 & $9-26-88$ & 10.07 & & & & \\
\hline
\end{tabular}

Map No. 23. South Mill-D 2S/6W-15C3. Depth of well: 400 feet. Measuring point: 27.22 feet. Top and bottom of open interval 372-387 feet.

\begin{tabular}{rrrrrrrr}
\hline $9-20-89$ & 16.37 & $11-21-89$ & -21.83 & $12-06-89$ & -21.05 & $2-06-90$ & -19.50 \\
$10-24-89$ & -25.66 & & & & & & \\
\hline
\end{tabular}

Map No. 24. South Mill-M 2S/6W-15C4. Depth of well: 140 feet. Measuring point: 27.35 feet. Top and bottom of open interval 118-138 feet.

\begin{tabular}{rrrrrrrr}
\hline $9-20-89$ & 0.54 & $11-21-89$ & 13.56 & $6-05-90$ & 7.00 & $12-04-90$ & 12.82 \\
$10-16-89$ & 14.24 & $12-04-89$ & 13.70 & $7-02-90$ & 10.26 & $2-06-91$ & 12.36 \\
$10-18-89$ & 14.06 & $2-06-90$ & 12.07 & $8-01-90$ & 11.47 & $5-01-90$ & 12.99 \\
$10-19-89$ & 13.50 & $3-06-90$ & 12.98 & $9-05-90$ & 10.03 & $9-17-91$ & -2.43 \\
$10-20-89$ & 11.87 & $4-04-90$ & 13.67 & $10-10-90$ & 10.49 & $9-19-91$ & 9.84 \\
$10-24-89$ & 13.63 & $5-01-90$ & 9.65 & $11-06-90$ & 12.95 & $2-04-92$ & 9.50 \\
\hline
\end{tabular}

Map No. 25. South Mill-S 2S/6W-15C5. Depth of well: 57 feet. Measuring point: 27.23 feet. Top and bottom of open interval 30-50 feet.

\begin{tabular}{rrrrrrrr}
\hline $9-20-89$ & 12.69 & $11-21-89$ & 14.72 & $6-05-90$ & 10.08 & $12-04-90$ & 13.71 \\
$10-16-89$ & 15.20 & $12-04-89$ & 14.92 & $7-02-90$ & 12.66 & $2-06-91$ & 13.43 \\
$10-18-89$ & 15.13 & $2-06-90$ & 13.76 & $8-01-90$ & 13.43 & $5-01-91$ & 13.89 \\
$10-19-89$ & 14.88 & $3-06-90$ & 14.47 & $9-05-90$ & 12.33 & $9-17-91$ & 4.03 \\
$10-20-89$ & 13.58 & $4-04-90$ & 14.85 & $10-10-90$ & 12.59 & $9-19-91$ & 10.60 \\
$10-24-89$ & 14.94 & $5-01-90$ & 11.53 & $11-06-90$ & 13.85 & $2-04-92$ & 11.83 \\
\hline
\end{tabular}

Map No. 26. HLA C 2S/6W-15F1. Depth of well: 55 feet. Measuring point: 19.92 feet.

\begin{tabular}{rrrrrrrr}
\hline $10-14-87$ & 11.96 & $2-24-88$ & 12.26 & $5-18-88$ & 10.89 & $8-15-88$ & 11.12 \\
$12-10-87$ & 12.54 & $3-28-88$ & 11.92 & $6-14-88$ & 10.97 & $9-26-88$ & 11.02 \\
$1-15-88$ & 12.69 & $4-20-88$ & 12.07 & $7-19-88$ & 10.95 & & \\
\hline
\end{tabular}

Map No. 27. HLA D 2S/6W-15F2. Depth of well: 52 feet. Measuring point: 26.98 feet.

\begin{tabular}{rrrrrrrr}
\hline $10-14-87$ & 15.37 & $2-24-88$ & 15.91 & $5-18-88$ & 15.28 & $8-15-88$ & 14.59 \\
$12-10-87$ & 15.23 & $3-28-88$ & 15.44 & $6-14-88$ & 15.00 & $9-26-88$ & 15.14 \\
$1-15-88$ & 16.01 & $4-20-88$ & 15.63 & $7-19-88$ & 14.62 & &
\end{tabular}


Table 16. Water-level and construction data for wells in San Francisco and part of San Mateo Counties--Continued

\begin{tabular}{|c|c|c|c|c|c|c|c|}
\hline Date & $\begin{array}{l}\text { Water-level } \\
\text { altitude }\end{array}$ & Date & $\begin{array}{l}\text { Water-level } \\
\text { altitude }\end{array}$ & Date & $\begin{array}{l}\text { Water-level } \\
\text { altitude }\end{array}$ & Date & $\begin{array}{l}\text { Water-level } \\
\text { altitude }\end{array}$ \\
\hline
\end{tabular}

Map No. 28. Moraga North 2S/6W-15K1. Depth of well: 260 feet. Measuring point: 59.34 feet.

\begin{tabular}{lrrrrrrr}
\hline $3-28-88$ & 15.20 & $8-15-88$ & 13.56 & $2-07-90$ & 13.69 & $2-06-91$ & 13.03 \\
$4-20-88$ & 15.46 & $9-26-88$ & 12.98 & $5-02-90$ & 13.10 & $5-02-91$ & 13.02 \\
$5-18-88$ & 13.95 & $11-09-88$ & 13.63 & $8-02-90$ & 13.01 & $9-18-91$ & 11.47 \\
$6-14-88$ & 13.73 & $3-16-89$ & 14.47 & $11-07-90$ & 12.84 & $2-05-92$ & 12.51 \\
$7-19-88$ & 13.23 & $10-27-89$ & 13.59 & & & & \\
\hline
\end{tabular}

Map No. 29. Lawton North 2S/6W-15K3. Depth of well: 282 feet. Measuring point: 73.16 feet.

\begin{tabular}{rrrrrrrr}
\hline $10-27-87$ & 25.56 & $12-09-87$ & 25.51 & $2-24-88$ & 25.44 & $3-28-88$ & 25.11 \\
$11-05-87$ & 25.60 & $1-15-88$ & 25.51 & & & & \\
\hline
\end{tabular}

Map No. 30. HLA E 2S/6W-15P1. Depth of well: 68 feet. Measuring point: 22.64 feet.

\begin{tabular}{rrrrrrrr}
\hline $10-14-87$ & 10.04 & $5-17-88$ & 8.64 & $3-16-89$ & 9.07 & $11-07-90$ & 8.34 \\
$11-18-87$ & 9.67 & $6-14-88$ & 8.61 & $10-27-89$ & 8.72 & $1-09-91$ & 8.24 \\
$12-10-87$ & 10.64 & $7-19-88$ & 8.66 & $2-07-90$ & 8.96 & $2-06-91$ & 8.49 \\
$1-15-88$ & 10.57 & $8-15-88$ & 8.67 & $4-05-90$ & 8.71 & $5-02-91$ & 8.03 \\
$2-24-88$ & 10.10 & $9-26-88$ & 8.53 & $5-02-90$ & 7.97 & $9-18-91$ & 7.53 \\
$3-28-88$ & 9.74 & $11-09-88$ & 8.82 & $8-02-90$ & 8.27 & $2-05-92$ & 8.91 \\
$4-20-88$ & 9.75 & & & & & & \\
\hline
\end{tabular}

Map No. 31. HLA F 2S/6W-15P2. Depth of well: 85 feet. Measuring point: 21.75 feet.

\begin{tabular}{rrrrrrrr}
\hline $10-14-87$ & 9.41 & $2-24-88$ & 9.23 & $5-13-88$ & 5.58 & $7-19-88$ & 5.13 \\
$12-10-87$ & 10.13 & $3-28-88$ & 9.26 & $6-14-88$ & 5.10 & $8-15-88$ & 6.10 \\
$1-15-88$ & 9.11 & $4-20-88$ & 8.67 & & & & \\
\hline
\end{tabular}

Map No. 32. HLA G 2S/6W-22F1. Depth of well: 35 feet. Measuring point: 21.91 feet.

\begin{tabular}{lllllrrr}
\hline $10-14-87$ & 10.84 & $1-15-88$ & 11.54 & $4-20-88$ & 11.13 & $7-19-88$ & 1.27 \\
$11-19-87$ & 10.89 & $2-24-88$ & 11.43 & $5-18-88$ & 3.54 & $8-15-88$ & 2.49 \\
$12-10-87$ & 11.49 & $3-28-88$ & 11.07 & $6-14-88$ & 1.55 & $9-26-88$ & 3.66 \\
\hline
\end{tabular}

Map No. 33. Santiago South 2S/6W-22J1. Depth of well: 250 feet. Measuring point: 63.33 feet.

\begin{tabular}{rrrrrrrr}
\hline $10-14-87$ & 14.37 & $5-18-88$ & 12.64 & $3-16-89$ & 13.38 & $11-07-90$ & 11.91 \\
$12-09-87$ & 15.06 & $6-14-88$ & 12.11 & $10-27-89$ & 12.65 & $2-06-91$ & 12.11 \\
$1-15-88$ & 14.83 & $7-19-88$ & 10.83 & $2-08-90$ & 12.91 & $5-02-91$ & 11.99 \\
$2-24-88$ & 14.55 & $8-15-88$ & 12.06 & $5-02-90$ & 12.43 & $9-18-91$ & 11.58 \\
$3-28-88$ & 14.42 & $9-26-88$ & 12.13 & $8-02-90$ & 12.04 & $2-05-92$ & 11.65 \\
$4-20-88$ & 14.61 & $11-09-88$ & 12.61 & & & & \\
\hline
\end{tabular}

Map No. 34. HLA I 2S/6W-22K1. Depth of well: 61 feet. Measuring point: 32.59 feet.

\begin{tabular}{rrrrrrrr}
\hline $10-14-87$ & 16.43 & $5-18-88$ & 15.69 & $3-16-89$ & 14.64 & $11-07-90$ & 13.24 \\
$12-10-87$ & 16.12 & $6-14-88$ & 16.04 & $10-26-89$ & 14.54 & $2-06-91$ & 12.95 \\
$1-15-88$ & 16.22 & $7-19-88$ & 14.84 & $2-07-90$ & 14.29 & $5-02-91$ & 13.05 \\
$2-24-88$ & 16.59 & $8-15-88$ & 14.55 & $5-02-90$ & 14.07 & $9-18-91$ & 12.72 \\
$3-28-88$ & 16.50 & $9-26-88$ & 14.42 & $8-02-90$ & 13.57 & $2-05-92$ & 12.57 \\
$4-20-88$ & 16.47 & $11-09-88$ & 14.42 & & & &
\end{tabular}


Table 16. Water-level and construction data for wells in San Francisco and part of San Mateo Counties--Continued

\begin{tabular}{cccccccc}
\hline \multicolumn{1}{l}{ Date } & $\begin{array}{c}\text { Water-level } \\
\text { altitude }\end{array}$ & \multicolumn{1}{c}{ Date } & $\begin{array}{c}\text { Water-level } \\
\text { altitude }\end{array}$ & Date & $\begin{array}{c}\text { Water-level } \\
\text { altitude }\end{array}$ & $\begin{array}{c}\text { Date } \\
\text { Map No. 35. HLA H 2S/6W-22K2. Depth of well: } 41 \text { feet. }\end{array}$ Measuring point: 21.17 feet. \\
\hline 10-14-87 & 8.62 & $5-18-88$ & 7.18 & $3-16-89$ & 7.98 & $11-07-90$ & 7.17 \\
$12-10-87$ & 9.32 & $6-14-88$ & 5.67 & $10-26-89$ & 7.75 & $2-06-91$ & 7.67 \\
$1-15-88$ & 9.47 & $7-19-88$ & 5.24 & $2-07-90$ & 8.31 & $5-02-91$ & 7.56 \\
$2-24-88$ & 9.04 & $8-15-88$ & 5.59 & $5-02-90$ & 7.89 & $9-18-91$ & 7.24 \\
$3-28-88$ & 8.67 & $9-26-88$ & 6.15 & $8-02-90$ & 6.54 & $2-04-92$ & 8.10 \\
$4-20-88$ & 8.61 & $11-09-88$ & 7.12 & & & & \\
\hline
\end{tabular}

Map No. 36. HLA J 2S/6W-22Q1. Depth of well: 66 feet. Measuring point: 21.43 feet.

\begin{tabular}{rrrrrrrr}
\hline $10-14-87$ & 9.48 & $2-24-88$ & 9.85 & $5-18-88$ & 8.62 & $8-15-88$ & 7.92 \\
$11-20-87$ & 8.93 & $3-28-88$ & 9.44 & $6-14-88$ & 8.06 & $9-26-88$ & 7.79 \\
$12-10-87$ & 9.98 & $4-20-88$ & 9.43 & $7-19-88$ & 7.91 & $1-09-91$ & 8.01 \\
$1-15-88$ & 10.13 & & & & & & \\
\hline
\end{tabular}

Map No. 37. Edgewood School 2S/6W-23Q1. Depth of well: 214 feet. Measuring point: 157.70 feet.

\begin{tabular}{rrrrrrrr}
\hline $10-20-88$ & 49.05 & $10-27-89$ & 47.11 & $8-02-90$ & 45.98 & $5-02-91$ & 44.62 \\
$11-15-88$ & 49.38 & $2-07-90$ & 46.78 & $11-07-90$ & 45.20 & $9-18-91$ & 43.74 \\
$3-16-89$ & 48.58 & $5-02-90$ & 46.59 & $2-06-91$ & 44.88 & & \\
\hline
\end{tabular}

Map No. 38. San Francisco State 2S/6W-25N1. Depth of well: 250 feet. Measuring point: 117.11 feet. Top and bottom of open interval 48-95, 169-240 feet.

\begin{tabular}{rlllllll}
\hline $6-06-67$ & 114.1 & $2-24-88$ & 116.39 & $5-18-88$ & 113.77 & $8-15-88$ & 112.89 \\
$12-10-87$ & 113.77 & $3-28-88$ & 115.17 & $6-14-88$ & 113.85 & $9-26-88$ & 111.89 \\
$1-15-88$ & 115.96 & $4-20-88$ & 115.71 & $7-19-88$ & 113.42 & & \\
\hline
\end{tabular}

Map No. 39. Stern Monument 2S/6W-26A1. Depth of well: 269 feet. Measuring point: 83.90 feet.

\begin{tabular}{rrrrrrrr}
\hline $10-01-87$ & 61.41 & $7-19-88$ & 62.77 & $8-15-89$ & 60.68 & $7-02-90$ & 59.98 \\
$10-28-87$ & 58.32 & $8-15-88$ & 60.58 & $9-18-89$ & 59.65 & $8-02-90$ & 59.71 \\
$11-05-87$ & 63.24 & $9-26-88$ & 62.55 & $10-24-89$ & 60.97 & $9-05-90$ & 59.52 \\
$12-09-87$ & 63.05 & $11-09-88$ & 62.87 & $11-20-89$ & 60.88 & $10-10-90$ & 59.72 \\
$1-15-88$ & 63.61 & $1-04-89$ & 62.90 & $12-05-89$ & 61.08 & $11-07-90$ & 59.24 \\
$2-24-88$ & 63.60 & $2-07-89$ & 62.66 & $2-07-90$ & 60.87 & $12-04-90$ & 59.42 \\
$3-28-88$ & 63.70 & $3-14-89$ & 62.63 & $3-06-90$ & 58.85 & $2-05-91$ & 59.28 \\
$4-20-88$ & 63.97 & $4-24-89$ & 62.73 & $4-04-90$ & 60.63 & $5-02-91$ & 59.10 \\
$5-18-88$ & 63.73 & $5-31-89$ & 61.98 & $5-02-90$ & 58.83 & $9-18-91$ & 58.24 \\
$6-14-88$ & 63.31 & $7-06-89$ & 60.87 & $6-05-90$ & 58.12 & $2-05-92$ & 57.79 \\
\hline
\end{tabular}

Map No. 40. Harding Park 2S/6W-26P1. Depth of well: 265 feet. Measuring point: 67.78 feet. Top and bottom of open interval 50-144, 144-265 feet.

\begin{tabular}{rrrrrrrr}
\hline $5-08-57$ & 26.00 & $9-26-88$ & 8.75 & $10-19-89$ & 6.93 & $7-02-90$ & 7.18 \\
$10-21-87$ & 9.38 & $11-09-88$ & 8.09 & $10-20-89$ & 6.93 & $8-02-90$ & 7.08 \\
$12-10-87$ & 10.20 & $1-04-89$ & 9.03 & $10-24-89$ & 7.34 & $9-05-90$ & 6.78 \\
$1-15-88$ & 6.69 & $2-08-89$ & 8.87 & $11-20-89$ & 7.61 & $10-10-90$ & 6.78 \\
$2-24-88$ & 10.46 & $3-15-89$ & 9.19 & $12-05-89$ & 7.73 & $11-06-90$ & 6.85 \\
$3-28-88$ & 10.11 & $4-25-89$ & 8.82 & $2-07-90$ & 8.38 & $12-04-90$ & 6.90 \\
$4-20-88$ & 10.10 & $5-31-89$ & 7.89 & $3-06-90$ & 8.54 & $2-05-91$ & 7.08 \\
$5-17-88$ & 9.79 & $7-06-89$ & 7.42 & $4-05-90$ & 8.05 & $5-01-91$ & 7.03 \\
$6-14-88$ & 9.40 & $8-15-89$ & 7.36 & $5-02-90$ & 7.56 & $9-18-91$ & 6.33 \\
$7-19-88$ & 8.85 & $9-18-89$ & 7.66 & $6-05-90$ & 7.75 & $2-04-92$ & 6.65 \\
$8-15-88$ & 9.04 & $10-18-89$ & 7.01 & & & &
\end{tabular}


Table 16. Water-level and construction data for wells in San Francisco and part of San Mateo Counties--Continued

\begin{tabular}{lccccccc}
\hline Date & $\begin{array}{c}\text { Water-level } \\
\text { altitude }\end{array}$ & Date & $\begin{array}{c}\text { Water-level } \\
\text { altitude }\end{array}$ & Date & $\begin{array}{c}\text { Water-level } \\
\text { altitude }\end{array}$ & Date & $\begin{array}{c}\text { Water-level } \\
\text { altitude }\end{array}$ \\
\hline Map No. 41. HLA O 2S/6W-27B1. Depth of well: 53 feet. & Measuring point: 39.02 feet. & & \\
\hline $10-14-87$ & 12.52 & $2-24-88$ & 12.37 & $5-18-88$ & 12.50 & $8-15-88$ & 12.19 \\
$12-10-87$ & 14.02 & $3-28-88$ & 12.83 & $6-14-88$ & 12.38 & $9-26-88$ & 11.59 \\
$1-23-88$ & 12.22 & $4-20-88$ & 13.15 & $7-19-88$ & 12.15 & & \\
\hline
\end{tabular}

Map No. 42. HLA K 2S/6W-27B3. Depth of well: 74 feet. Measuring point: 22.44 feet.

\begin{tabular}{llllllll}
\hline $10-14-87$ & 10.87 & $1-15-88$ & 11.69 & $4-20-88$ & 10.75 & $7-19-88$ & 10.32 \\
$11-20-87$ & 10.44 & $2-24-88$ & 11.16 & $5-18-88$ & 10.48 & $8-15-88$ & 10.32 \\
$12-10-87$ & 10.57 & $3-28-88$ & 10.82 & $6-14-88$ & 10.47 & $9-26-88$ & 10.10 \\
\hline
\end{tabular}

Map No. 43. HLA L 2S/6W-27B4. Depth of well: 66 feet. Measuring point: 21.91 feet.

\begin{tabular}{rlllllll}
\hline $10-14-87$ & 10.89 & $2-24-88$ & 11.13 & $5-18-88$ & 10.53 & $8-15-88$ & 10.29 \\
$12-10-87$ & 11.56 & $3-28-88$ & 10.82 & $6-14-88$ & 10.41 & $9-26-88$ & 10.07 \\
$1-15-88$ & 11.70 & $4-20-88$ & 10.80 & $7-19-88$ & 10.46 & & \\
\hline
\end{tabular}

Map No. 44. Zoo 03 2S/6W-27B5. Depth of well: 220 feet. Measuring point: 11.32 feet.

\begin{tabular}{rrrrrrrr}
\hline $11-09-88$ & 6.07 & $4-25-89$ & 8.84 & $8-15-89$ & 6.17 & $11-20-89$ & -39.06 \\
$1-04-89$ & .84 & $6-01-89$ & -1.57 & $9-18-89$ & 7.85 & $11-21-89$ & 7.70 \\
$2-08-89$ & 9.03 & $7-06-89$ & 6.09 & $10-24-89$ & 8.56 & $12-05-89$ & 8.24 \\
$3-15-89$ & 8.31 & & & & & & \\
\hline
\end{tabular}

Map No. 45. Zoo 04 2S/6W-27B6. Depth of well: 220 feet. Measuring point: 12.62 feet.

\begin{tabular}{rrrrrrrr}
\hline $11-09-88$ & 6.69 & $8-18-89$ & 8.32 & $3-07-90$ & 9.29 & $10-10-90$ & 7.48 \\
$2-08-89$ & 9.42 & $9-18-89$ & 8.32 & $4-05-90$ & 7.77 & $11-06-90$ & 7.93 \\
$3-15-89$ & 8.83 & $10-24-89$ & 8.95 & $5-01-90$ & 7.26 & $12-04-90$ & 8.32 \\
$4-25-89$ & 9.33 & $11-20-89$ & -1.72 & $6-06-90$ & 8.34 & $2-06-91$ & 8.56 \\
$7-06-89$ & 6.69 & $11-21-89$ & 8.19 & $7-02-90$ & 6.73 & $5-01-91$ & 8.13 \\
$8-15-89$ & 6.75 & $12-05-89$ & 8.72 & $8-01-90$ & 6.74 & $9-17-91$ & 7.16 \\
$8-16-89$ & 7.47 & $2-08-90$ & 9.58 & $9-05-90$ & 7.07 & $2-04-92$ & 8.13 \\
\hline
\end{tabular}

Map No. 46. HLA V 2S/6W-27J1. Depth of well: 53 feet. Measuring point: 48.90 feet.

\begin{tabular}{rrrrrrrr}
\hline $10-27-87$ & 11.80 & $6-14-88$ & 12.87 & $2-08-90$ & 10.26 & $11-07-90$ & 7.85 \\
$12-09-87$ & 11.82 & $7-19-88$ & 11.42 & $4-03-90$ & 10.46 & $12-04-90$ & 7.90 \\
$1-15-88$ & 12.52 & $8-25-88$ & 11.12 & $5-02-90$ & 10.32 & $2-06-91$ & 8.27 \\
$2-24-88$ & 12.49 & $9-26-88$ & 10.90 & $8-02-90$ & 8.37 & $5-01-91$ & 9.02 \\
$3-28-88$ & 12.17 & $11-09-88$ & 10.66 & $9-05-90$ & 7.80 & $9-18-91$ & 8.92 \\
$4-20-88$ & 11.99 & $3-16-89$ & 10.98 & $10-10-90$ & 7.91 & $2-05-92$ & 9.25 \\
$5-18-88$ & 11.83 & $10-26-89$ & 11.50 & & & & \\
\hline
\end{tabular}

Map No. 47. Fort Funston-D 2S/6W-34J1. Depth of well: 1,500 feet. Measuring point: 186.67 feet. Top and bottom of open interval $1,450-1,490$ feet.

\begin{tabular}{|c|c|c|c|c|c|c|c|}
\hline $\begin{array}{r}9-20-89 \\
10-25-89\end{array}$ & $\begin{array}{r}-155.62 \\
-91.09\end{array}$ & $\begin{array}{l}11-21-89 \\
12-06-89\end{array}$ & $\begin{array}{l}-74.05 \\
-89.93\end{array}$ & $2-08-90$ & -141.82 & $3-06-90$ & -133.90 \\
\hline
\end{tabular}


Table 16. Water-level and construction data for wells in San Francisco and part of San Mateo Counties--Continued

\begin{tabular}{|c|c|c|c|c|c|c|c|}
\hline Date & $\begin{array}{l}\text { Water-level } \\
\text { altitude }\end{array}$ & Date & $\begin{array}{l}\text { Water-level } \\
\text { altitude }\end{array}$ & Date & $\begin{array}{l}\text { Water-level } \\
\text { altitude }\end{array}$ & Date & $\begin{array}{c}\text { Water-level } \\
\text { altitude }\end{array}$ \\
\hline
\end{tabular}

Map No. 48. Fort Funston-M 2S/6W-34J2. Depth of well: 602 feet. Measuring point: 186.55 feet. Top and bottom of open interval 572-592 feet.

\begin{tabular}{rrrrrrrr}
\hline $9-20-89$ & -7.55 & $3-06-90$ & 23.89 & $8-02-90$ & 23.34 & $12-04-90$ & 22.51 \\
$10-25-89$ & -5.12 & $4-05-90$ & 20.24 & $9-05-90$ & 22.98 & $2-05-91$ & 22.33 \\
$11-21-89$ & -5.81 & $5-02-90$ & 23.93 & $10-10-90$ & 22.71 & $5-01-90$ & 21.93 \\
$12-06-89$ & -4.15 & $6-05-90$ & 23.64 & $11-06-90$ & 22.76 & $9-18-91$ & 21.50 \\
$2-08-90$ & 21.70 & $7-02-90$ & 23.44 & & & & \\
\hline
\end{tabular}

Map No. 49. Fort Funston-S 2S/6W-34J3. Depth of well: 278 feet. Measuring point: 186.48 feet. Top and bottom of open interval 250-270 feet.

\begin{tabular}{rrrrrrrr}
\hline $9-20-89$ & 7.66 & $3-06-90$ & 2.62 & $8-02-90$ & 2.65 & $2-05-91$ & 2.72 \\
$10-25-89$ & 3.69 & $4-05-90$ & 2.69 & $9-05-90$ & 2.57 & $5-01-91$ & 2.79 \\
$11-21-89$ & 2.99 & $5-02-90$ & 2.82 & $10-10-90$ & 2.70 & $9-18-91$ & 2.70 \\
$12-05-89$ & 2.72 & $6-05-90$ & 2.55 & $11-06-90$ & 2.78 & $2-05-92$ & 3.09 \\
$2-08-90$ & 2.63 & $7-02-90$ & 2.45 & $12-04-90$ & 2.64 & & \\
\hline
\end{tabular}

Map No. 50. Higuera 2S/6W-35H1. Depth of well: 87 feet. Measuring point: 90 feet.

\begin{tabular}{rrrrrrrr}
\hline $7-18-90$ & 7 & $9-05-90$ & 10 & $12-04-90$ & 10 & $9-18-91$ & 9 \\
$8-01-90$ & 10 & $10-10-90$ & 10 & $2-06-91$ & 10 & $2-05-92$ & 8 \\
$8-02-90$ & 10 & $11-06-90$ & 10 & $5-02-91$ & 10 & & \\
\hline
\end{tabular}

Map No. 51. Olympic Golf Club-S 2S/6W-35Q1. Depth of well: 51 feet. Measuring point: 31.30 feet. Top and bottom of open interval 36-46 feet.

\begin{tabular}{rrrrrrrr}
\hline $7-07-89$ & 2.67 & $11-20-89$ & 1.88 & $6-05-90$ & 1.45 & $12-04-90$ & 0.08 \\
$8-15-89$ & 2.30 & $12-06-89$ & 1.93 & $7-02-90$ & 1.20 & $1-09-91$ & .00 \\
$9-18-89$ & 2.05 & $2-07-90$ & 2.03 & $8-01-90$ & .94 & $2-05-91$ & -.10 \\
$10-18-89$ & 1.83 & $3-06-90$ & 2.00 & $9-05-90$ & .65 & $5-01-91$ & -.08 \\
$10-19-89$ & 1.85 & $4-03-90$ & 1.84 & $10-10-90$ & .40 & $9-17-91$ & -.90 \\
$10-20-89$ & 1.85 & $5-02-90$ & 1.65 & $11-06-90$ & .22 & $2-05-92$ & -1.12 \\
$10-24-89$ & 1.91 & & & & & & \\
\hline
\end{tabular}

Map No. 52. San Francisco Golf Club, East-D 2S/6W-36N1. Depth of well: 324 feet. Measuring point: 143.02 feet. Top and bottom of open interval 200-310 feet.

\begin{tabular}{rrrrrrrr}
\hline $4-24-51$ & 83 & $6-05-90$ & -33.98 & $12-04-90$ & -35.40 & $9-17-91$ & -36.27 \\
$4-05-90$ & -33.90 & $7-02-90$ & -35.82 & $2-05-91$ & -34.85 & $2-04-92$ & -35.40 \\
$5-02-90$ & -35.05 & $8-01-90$ & -35.25 & $5-01-91$ & -35.40 & & \\
\hline
\end{tabular}

Map No. 53. San Francisco Golf Club, West-D 2S/6W-36N2. Depth of well: 540 feet. Measuring point: 139.10 feet. Top and bottom of open interval 360-540 feet.

\begin{tabular}{rrrrrrrr}
\hline $1-05-89$ & -52.90 & $4-25-89$ & -63.24 & $3-06-90$ & -59.72 & $9-05-90$ & -64.71 \\
$2-08-89$ & -51.37 & $10-25-89$ & -61.10 & $5-02-90$ & -74.16 & $10-10-90$ & -64.03 \\
$3-20-89$ & -53.66 & $2-07-90$ & -58.96 & $8-01-90$ & -71.62 & $11-06-90$ & -63.99
\end{tabular}


Table 16. Water-level and construction data for wells in San Francisco and part of San Mateo Counties--Continued

\begin{tabular}{|c|c|c|c|c|c|c|c|}
\hline Date & $\begin{array}{l}\text { Water-level } \\
\text { altitude }\end{array}$ & Date & $\begin{array}{l}\text { Water-level } \\
\text { altitude }\end{array}$ & Date & $\begin{array}{l}\text { Water-level } \\
\text { altitude }\end{array}$ & Date & $\begin{array}{l}\text { Water-level } \\
\text { altitude }\end{array}$ \\
\hline
\end{tabular}

Map No. 54. Holy Cross Cemetery 3S/5W-18K2. Depth of well: 688 feet. Measuring point: 81.69 feet. Top and bottom of open interval $368-458,478-668$ feet.

\begin{tabular}{rrrrrrrr}
\hline $5-15-86$ & -136.00 & $7-07-89$ & -132.99 & $2-07-90$ & -122.51 & $8-01-90$ & -134.07 \\
$1-05-89$ & -121.39 & $8-16-89$ & -135.51 & $3-06-90$ & -123.22 & $9-05-90$ & -134.93 \\
$2-08-89$ & -120.65 & $9-19-89$ & -128.23 & $4-05-90$ & -123.82 & $10-10-90$ & -132.30 \\
$3-15-89$ & -119.92 & $10-27-89$ & -125.99 & $5-01-90$ & -131.31 & $11-06-90$ & -132.35 \\
$4-25-89$ & -120.91 & $11-21-89$ & -125.60 & $6-05-90$ & -132.28 & $12-04-90$ & -126.39 \\
$5-31-89$ & -131.09 & $12-07-89$ & -123.79 & $7-02-90$ & -133.25 & $2-05-91$ & -122.94 \\
\hline
\end{tabular}

San Francisco Airport-D 3S/5W-34L1. Depth of well: 141 feet. Measuring point: 4.25 feet. Top and bottom of open interval 116-136 feet.

\begin{tabular}{rrrrrrrr}
\hline $10-17-89$ & -42.93 & $12-07-89$ & -38.14 & $7-02-90$ & -42.20 & $1-08-91$ & -43.17 \\
$10-18-90$ & -39.03 & $2-07-90$ & -38.76 & $8-01-90$ & -42.46 & $2-05-91$ & -42.54 \\
$10-19-89$ & -38.92 & $3-06-90$ & -38.77 & $9-05-90$ & -42.70 & $5-01-91$ & -41.69 \\
$10-20-89$ & -38.53 & $4-02-90$ & -38.30 & $10-10-90$ & -42.84 & $9-17-91$ & -42.71 \\
$10-27-89$ & -38.03 & $5-01-90$ & -42.06 & $11-06-90$ & -42.93 & $2-04-92$ & -44.42 \\
$11-22-89$ & -38.47 & $6-05-90$ & -42.19 & $12-04-90$ & -43.29 & & \\
\hline
\end{tabular}

San Francisco Airport-S 3S/5W-34L2. Depth of well: 35 feet. Measuring point: 4.28 feet. Top and bottom of open interval 20-30 feet.

\begin{tabular}{rrrrrrrr}
\hline $10-17-89$ & -1.24 & $12-07-89$ & -0.94 & $7-02-90$ & -1.30 & $1-08-91$ & -2.10 \\
$10-18-89$ & -.84 & $2-07-90$ & -.74 & $8-01-90$ & -1.53 & $2-05-91$ & -1.72 \\
$10-19-89$ & -.90 & $3-06-90$ & -.44 & $9-05-90$ & -1.44 & $5-01-91$ & -.68 \\
$10-20-89$ & -.96 & $4-02-90$ & -.50 & $10-10-90$ & -1.63 & $9-17-91$ & -2.02 \\
$10-27-89$ & -.81 & $5-01-90$ & -.74 & $11-06-90$ & -1.96 & $2-04-92$ & -1.10 \\
$11-22-89$ & -.96 & $6-05-90$ & -.94 & $12-04-90$ & -2.29 & & \\
\hline
\end{tabular}

Map No. 55. San Francisco Golf Club-S 3S/6W-2A1. Depth of well: 62 feet. Measuring point: 40.90 feet. Top and bottom of open interval 49-59 feet.

\begin{tabular}{rrrrrrrr}
\hline $7-07-89$ & 2.90 & $10-25-89$ & 2.29 & $6-06-90$ & 1.66 & $12-04-90$ & 0.60 \\
$8-15-89$ & 2.75 & $11-21-89$ & 2.22 & $7-02-90$ & 1.57 & $1-09-91$ & .51 \\
$9-19-89$ & 2.48 & $12-07-89$ & 2.09 & $8-01-90$ & 1.40 & $2-05-91$ & .38 \\
$10-17-89$ & 2.23 & $2-07-90$ & 1.98 & $9-05-90$ & 1.16 & $5-01-91$ & .12 \\
$10-18-89$ & 2.37 & $3-06-90$ & 1.94 & $10-10-90$ & .98 & $9-17-91$ & -.48 \\
$10-19-89$ & 2.28 & $4-03-90$ & 1.97 & $11-06-90$ & .80 & $2-04-92$ & -1.02 \\
$10-20-89$ & 2.28 & $5-02-90$ & 1.81 & & & & \\
\hline
\end{tabular}

Map No. 56. Olympic Golf Club-D 3S/6W-2B3. Depth of well: 524 feet. Measuring point: 61.52 feet. Top and bottom of open interval 242-499 feet.

\begin{tabular}{rrrrrrrr}
\hline $8-24-88$ & -32.00 & $7-07-89$ & -44.14 & $3-06-90$ & -29.43 & $11-06-90$ & -35.36 \\
$11-09-88$ & -31.78 & $8-15-89$ & -38.36 & $4-03-90$ & -33.47 & $12-04-90$ & -33.99 \\
$1-05-89$ & -30.04 & $9-18-89$ & -34.37 & $5-02-90$ & -38.73 & $2-05-91$ & -32.90 \\
$2-08-89$ & -29.77 & $10-24-89$ & -32.55 & $6-05-90$ & -35.85 & $5-01-91$ & -35.50 \\
$3-15-89$ & -29.31 & $11-20-89$ & -37.73 & $8-01-90$ & -37.51 & $9-17-91$ & -37.02 \\
$4-25-89$ & -32.68 & $12-07-89$ & -31.45 & $9-05-90$ & -38.82 & $2-04-92$ & -33.43 \\
$5-31-89$ & -38.31 & $2-07-90$ & -29.48 & $10-10-90$ & -37.03 & & \\
\hline
\end{tabular}


Table 17. Chemical composition of ground and surface water in San Francisco and part of San Mateo Counties

[D, deep; $\mathrm{M}$, medium; $\mathrm{S}$, shallow. $\mathrm{ft}$, foot; $\mu \mathrm{S} / \mathrm{cm}$, microsiemen per centimeter; $\mu \mathrm{g} / \mathrm{L}$, microgram per liter; $\mathrm{mg} / \mathrm{L}$, milligram per liter. --, no data. na, not applicable]

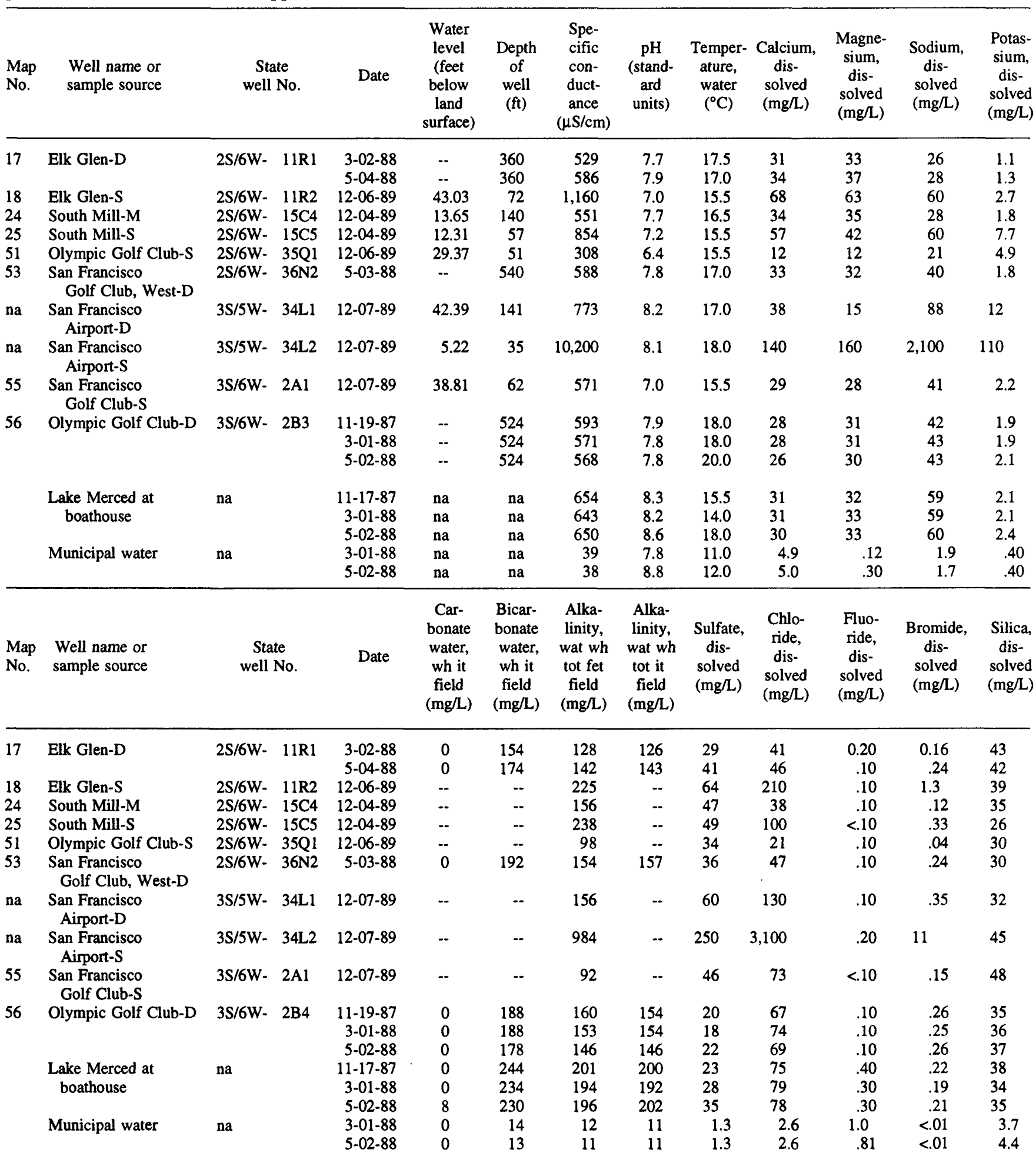


Table 17. Chemical composition of ground and surface water in San Francisco and part of San Mateo Counties--Continued

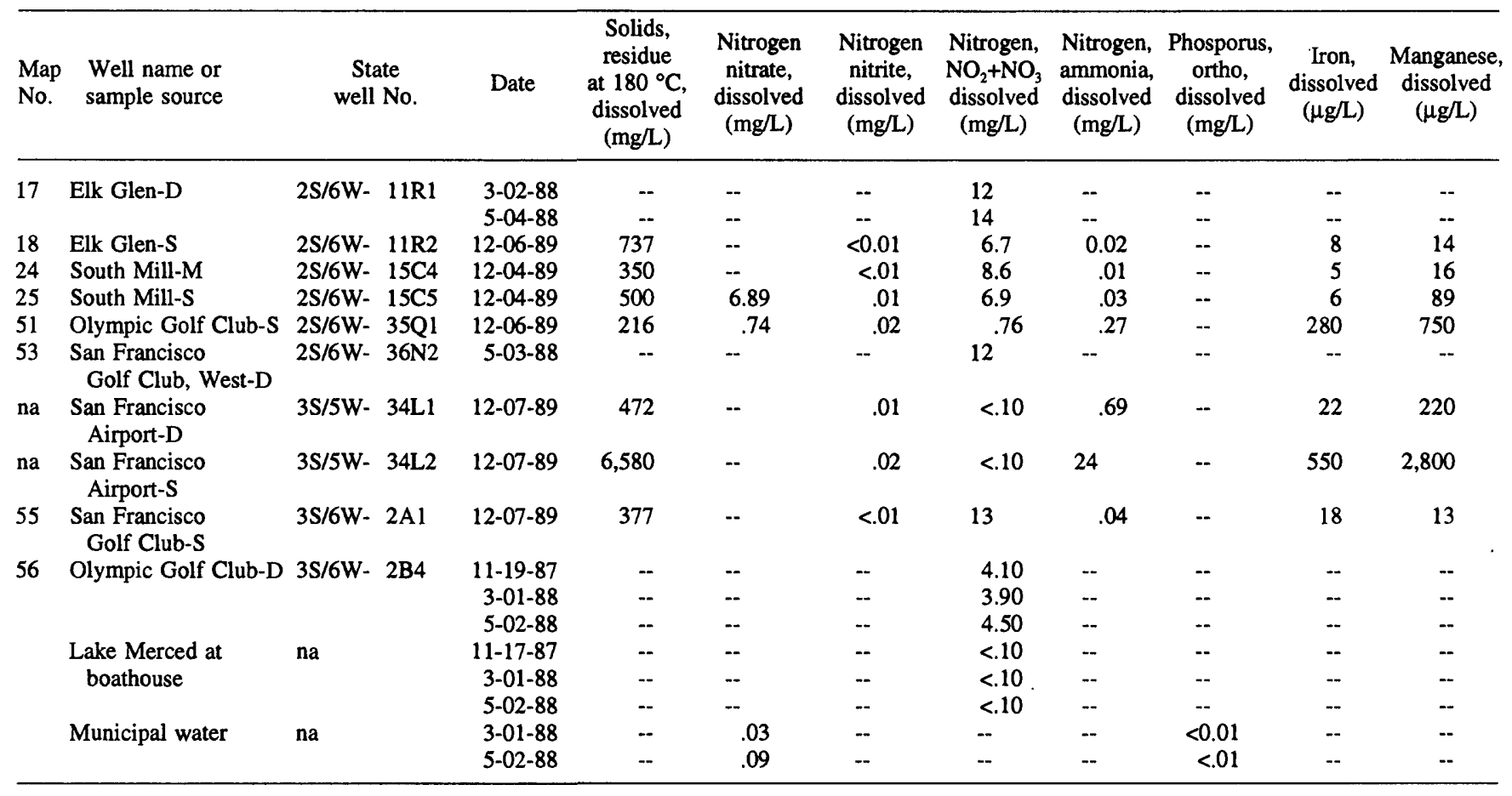


Table 18. Input values for variables used in the calibrated hydrologic routing model that vary by month [Explanations for variables are given in Appendix 1]

\begin{tabular}{|c|c|c|c|c|c|c|c|c|c|c|c|c|}
\hline Year & Oct & Nov & Dec & Jan & Feb & Mar & Apr & May & June & July & Aug & Sept \\
\hline \multicolumn{13}{|c|}{ RAIN } \\
\hline \multicolumn{13}{|c|}{ Richmond-Sunset, AVGRAIN=21.32 } \\
\hline 1987 & 0.12 & 0.19 & 1.43 & 4.19 & 3.42 & 2.48 & 0.20 & 0.09 & 0.00 & 0.00 & 0.00 & 0.00 \\
\hline 1988 & 1.86 & 2.33 & 3.97 & 5.45 & .68 & .10 & 1.42 & .66 & .35 & .00 & .00 & .00 \\
\hline \multicolumn{13}{|c|}{ Mission Dolores, AVGRAIN $=23.70$} \\
\hline 1978 & 0.11 & 0.20 & 1.64 & 4.26 & 3.77 & 2.31 & 0.14 & 0.06 & 0.01 & 0.00 & 0.00 & 0.00 \\
\hline 1988 & 1.07 & 3.09 & 5.09 & 4.93 & .40 & .07 & 1.73 & .66 & .70 & .00 & .00 & .00 \\
\hline \multicolumn{13}{|c|}{ San Francisco Airport, AVGRAIN=22.38 } \\
\hline 1987 & 0.02 & 0.06 & 1.66 & 2.80 & 3.52 & 1.98 & 0.16 & 0.06 & 0.00 & 0.00 & 0.00 & 0.00 \\
\hline 1988 & .93 & 1.64 & 4.51 & 3.92 & .38 & .05 & 2.02 & .29 & .60 & .00 & .00 & .03 \\
\hline \multicolumn{13}{|c|}{ DYLFR } \\
\hline \multicolumn{13}{|c|}{ AVGTEMP } \\
\hline 1987 & 61.4 & 57.1 & 50.3 & 49.3 & 53.3 & 54.9 & 59.2 & 61.6 & 62.4 & 63.1 & 65.16 & 64.0 \\
\hline 1988 & 63.9 & 57.0 & 50.3 & 50.6 & 54.5 & 56.5 & 58.1 & 59.5 & 62.5 & 65.3 & 65.06 & 63.1 \\
\hline
\end{tabular}




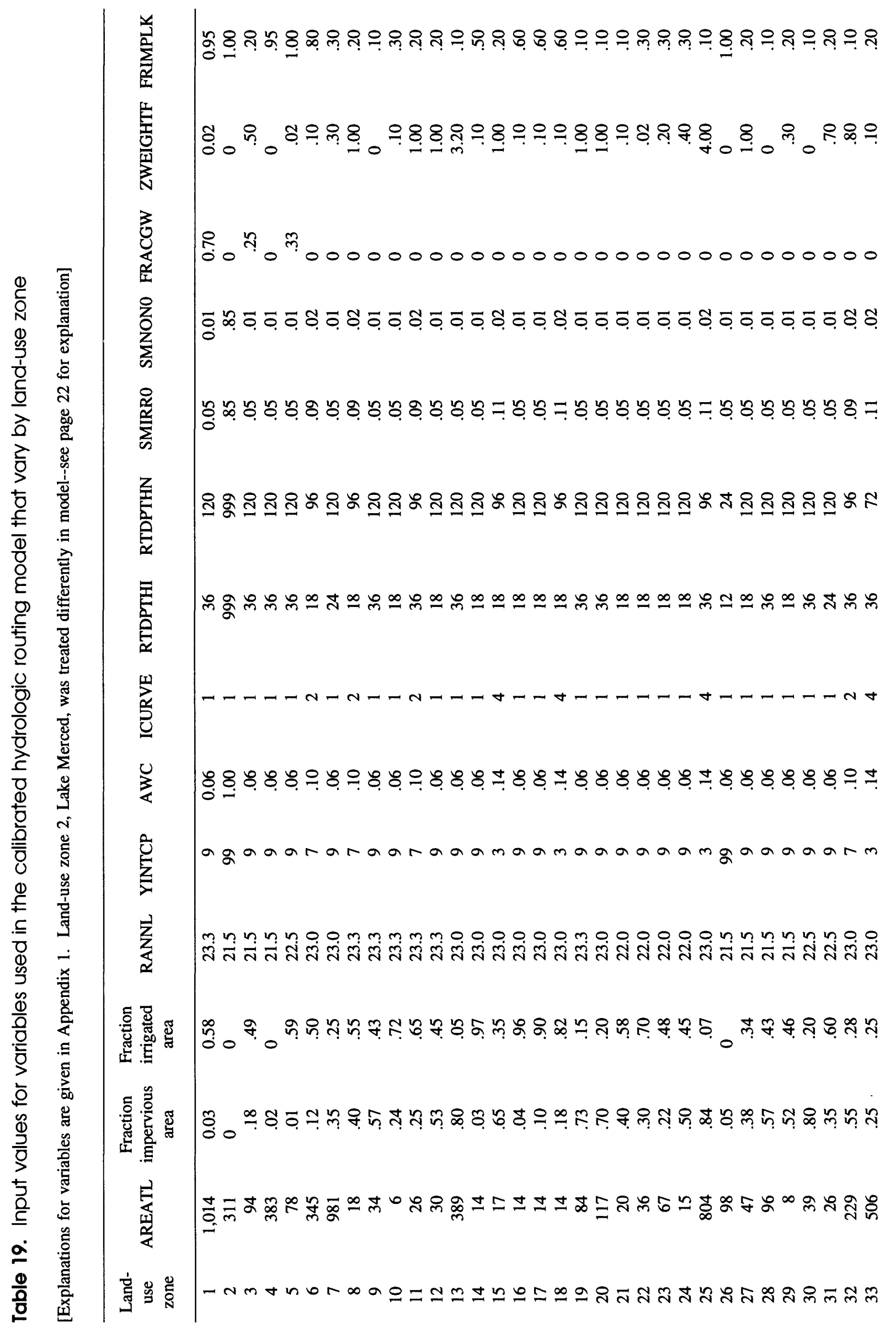




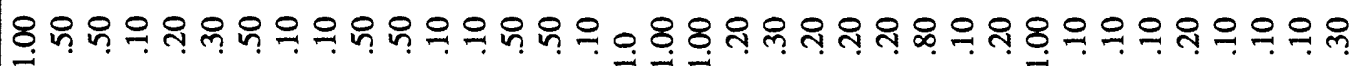

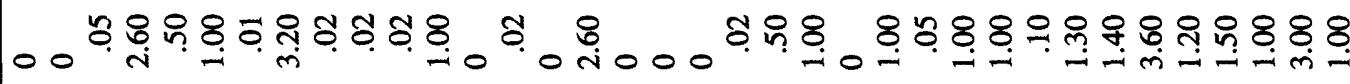

$0000000000000000-1-00000000000000000$

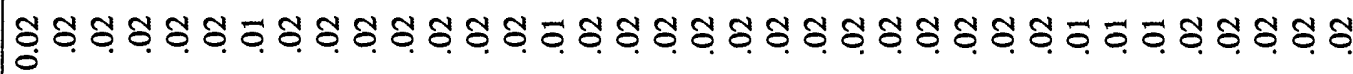

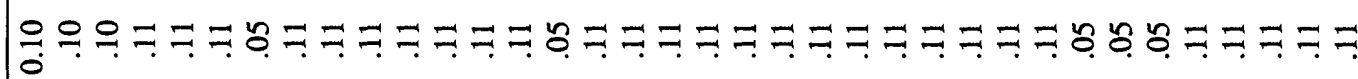

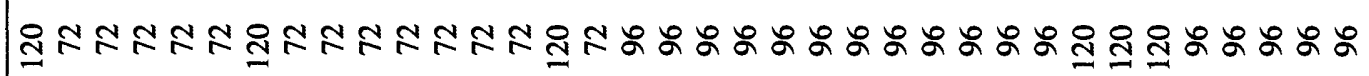
-

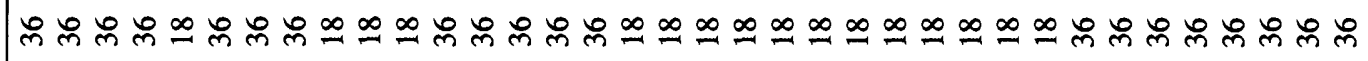

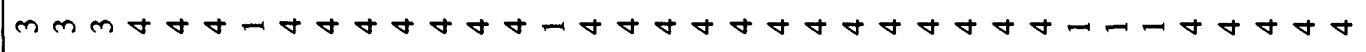

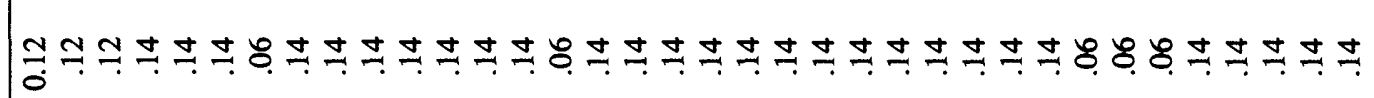

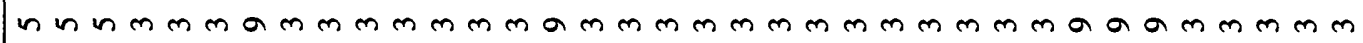

0000000000000000 nn n 000000000 nnm no 000

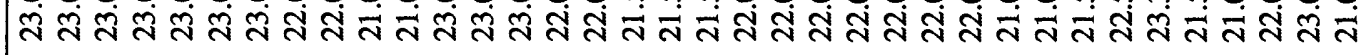

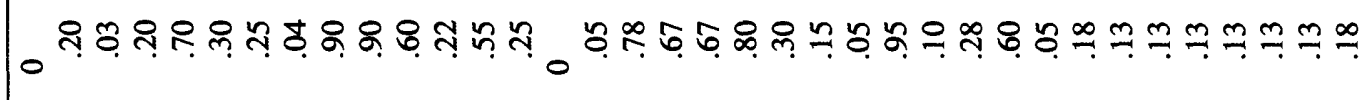

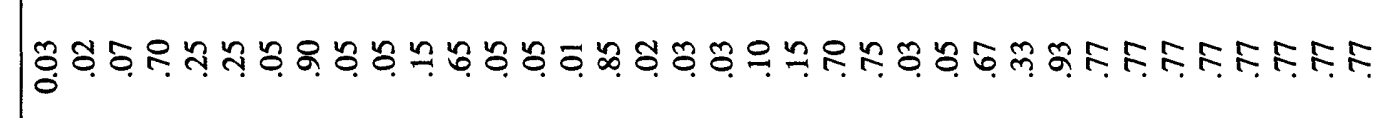

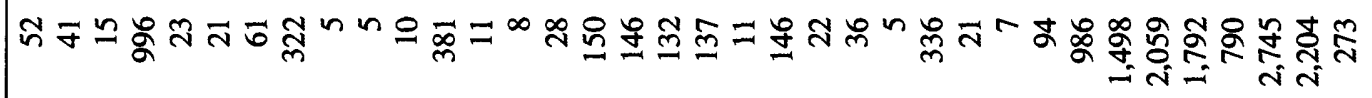




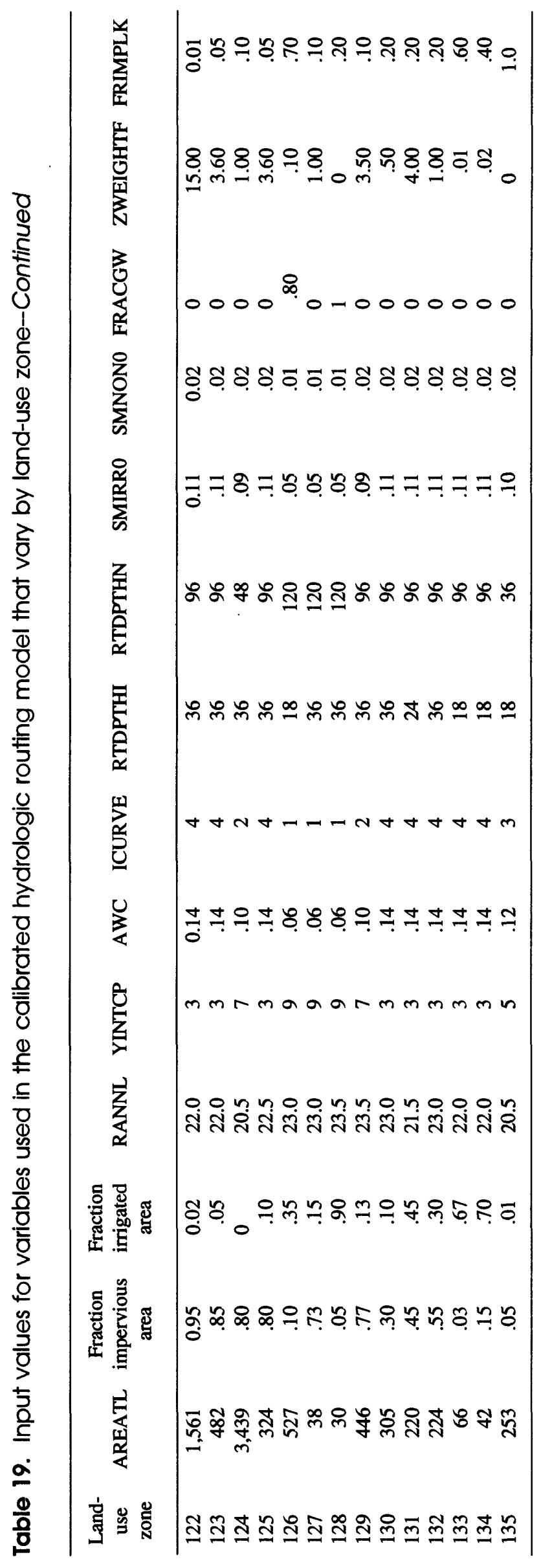


Table 20. Average annual output from the calibrated hydrologic routing model by land-use zone for

[Area in acres, all other values in acre-feet. For location of land-use zone, see fig. 8. Not all values add up to totals within the Fortran program and are a more accurate number than the sum of the integer values]

\begin{tabular}{|c|c|c|c|c|c|c|c|c|c|c|c|c|c|c|c|}
\hline \multirow[b]{3}{*}{$\begin{array}{l}\text { Land- } \\
\text { use } \\
\text { zone }\end{array}$} & \multirow[b]{3}{*}{ Rain } & \multirow{2}{*}{\multicolumn{4}{|c|}{ Impervious }} & \multicolumn{6}{|c|}{ Irrigated soil } & & & & \\
\hline & & & & & & \multirow[b]{2}{*}{ Area } & \multirow[b]{2}{*}{ Runoff } & \multirow[b]{2}{*}{$\begin{array}{l}\text { Evapo- } \\
\text { trans- } \\
\text { piration }\end{array}$} & \multicolumn{2}{|c|}{ Irrigation } & \multirow[b]{2}{*}{$\begin{array}{l}\text { Ground- } \\
\text { water } \\
\text { recharge }\end{array}$} & \multicolumn{4}{|c|}{ Nonirrigated soil } \\
\hline & & Area & $\begin{array}{c}\text { Depres- } \\
\text { sion } \\
\text { storage }\end{array}$ & $\begin{array}{c}\text { Runoff } \\
\text { to } \\
\text { sewer }\end{array}$ & $\begin{array}{l}\text { Ground- } \\
\text { water } \\
\text { recharge }\end{array}$ & & & & $\begin{array}{l}\text { Muni- } \\
\text { cipal } \\
\text { water }\end{array}$ & $\begin{array}{c}\text { Ground } \\
\text { water }\end{array}$ & & Area & Runoff & $\begin{array}{c}\text { Evapo- } \\
\text { trans- } \\
\text { piration }\end{array}$ & $\begin{array}{l}\text { Ground- } \\
\text { water } \\
\text { recharge }\end{array}$ \\
\hline 1 & 1,225 & 30.4 & 4 & 2 & 31 & 588.1 & 0 & 1,022 & 296 & 690 & 665 & 395.5 & 0 & 427 & 60 \\
\hline 2 & 347 & 0 & 0 & 0 & 0 & 0 & 0 & 0 & 0 & 0 & 0 & 311 & 0 & 542 & 0 \\
\hline 3 & 105 & 16.9 & 2 & 13 & 3 & 46.1 & 0 & 80 & 58 & 19 & 49 & 31 & 0 & 33 & 3 \\
\hline 4 & 427 & 7.7 & 1 & 0 & 7 & 0 & 0 & 0 & 0 & 0 & 0 & 375.3 & 0 & 396 & 32 \\
\hline 5 & 91 & .8 & 0 & 0 & 1 & 46 & 0 & 80 & 52 & 26 & 50 & 31.2 & 0 & 33 & 4 \\
\hline 6 & 412 & 41.4 & 5 & 9 & 35 & 172.5 & 0 & 300 & 275 & 0 & 179 & 131.1 & 0 & 152 & 6 \\
\hline 8 & 22 & 7.2 & 1 & 6 & 2 & 9.9 & 0 & 17 & 16 & 0 & 10 & .9 & 0 & 1 & 0 \\
\hline 9 & 41 & 19.4 & 2 & 19 & 2 & 14.6 & 0 & 25 & 24 & 0 & 17 & 0 & 0 & 0 & 0 \\
\hline 10 & 7 & 1.4 & 0 & 1 & 0 & 4.3 & 0 & 8 & 7 & 0 & 5 & .2 & 0 & 0 & 0 \\
\hline 11 & 31 & 6.5 & 1 & 6 & 1 & 16.9 & 0 & 29 & 28 & 0 & 20 & 2.6 & 0 & 3 & 0 \\
\hline 12 & 36 & 15.9 & 2 & 14 & 3 & 13.5 & 0 & 24 & 22 & 0 & 15 & .6 & 0 & 1 & 0 \\
\hline 19 & 101 & 61.3 & 8 & 60 & 7 & 12.6 & 0 & 22 & 21 & 0 & 14 & 10.1 & 0 & 11 & 2 \\
\hline 26 & 109 & 4.9 & 1 & 0 & 5 & 0 & 0 & 0 & 0 & 0 & 0 & 93.1 & 0 & 72 & 39 \\
\hline 27 & 52 & 17.9 & 2 & 14 & 4 & 16 & 0 & 28 & 27 & 0 & 17 & 13.2 & 0 & 14 & 1 \\
\hline 28 & 107 & 54.7 & 7 & 49 & 5 & 41.3 & 0 & 72 & 70 & 0 & 44 & 0 & 0 & 0 & 0 \\
\hline 29 & 9 & 4.2 & 1 & 3 & 1 & 3.7 & 0 & 6 & 6 & 0 & 4 & .2 & 0 & 0 & 0 \\
\hline 30 & 46 & 31.2 & 4 & 29 & 3 & 7.8 & 0 & 14 & 13 & 0 & 9 & 0 & 0 & 0 & 0 \\
\hline 31 & 30 & 9.1 & 1 & 8 & 2 & 15.6 & 0 & 27 & 25 & 0 & 16 & 1.3 & 0 & 1 & 0 \\
\hline 32 & 273 & 125.9 & 16 & 121 & 13 & 64.1 & 0 & 111 & 106 & 0 & 75 & 38.9 & 0 & 45 & 2 \\
\hline 33 & 604 & 126.5 & 16 & 108 & 27 & 126.5 & 17 & 219 & 201 & 0 & 121 & 253 & 35 & 253 & 0 \\
\hline 39 & 25 & 5.3 & 1 & 4 & 2 & 6.3 & 1 & 11 & 11 & 0 & 6 & 9.4 & 1 & 10 & 0 \\
\hline 40 & 73 & 3 & 0 & 2 & 2 & 15.3 & 0 & 27 & 26 & 0 & 17 & 42.7 & 0 & 46 & 6 \\
\hline 45 & 454 & 247.6 & 31 & 238 & 26 & 83.8 & 12 & 145 & 133 & 0 & 80 & 49.5 & 7 & 49 & 0 \\
\hline 50 & 163 & 2.9 & 0 & 0 & 3 & 113.9 & 11 & 199 & 0 & 186 & 101 & 29.2 & 3 & 27 & 0 \\
\hline 51 & 147 & 4.0 & 0 & 0 & 4 & 88.4 & 9 & 154 & 0 & 145 & 79 & 39.6 & 4 & 36 & 0 \\
\hline 52 & 153 & 4.1 & 1 & 0 & 4 & 91.8 & 9 & 160 & 0 & 150 & 82 & 41.1 & 4 & 38 & 0 \\
\hline 54 & 13 & 1.1 & 0 & 1 & 0 & 8.8 & 1 & 15 & 14 & 0 & 8 & 1.1 & 0 & 1 & 0 \\
\hline 111 & 1,099 & 759.2 & 93 & 678 & 75 & 177.5 & 0 & 309 & 300 & 0 & 187 & 49.3 & 0 & 52 & 4 \\
\hline 114 & 1,998 & $1,379.8$ & 169 & 1,096 & 274 & 233 & 22 & 402 & 373 & 0 & 217 & 179.2 & 17 & 165 & 0 \\
\hline 126 & 629 & 52.7 & 7 & 17 & 39 & 184.5 & 0 & 322 & 61 & 244 & 202 & 289.8 & 0 & 312 & 40 \\
\hline 131 & 245 & 99 & 12 & 79 & 20 & 99 & 10 & 172 & 170 & 0 & 95 & 22.0 & 2 & 20 & 0 \\
\hline Total & 13,310 & $5,881.0$ & 725 & 5,207 & 896 & $2,764.1$ & 91 & 4,802 & 3,112 & 1,460 & 2,898 & $2,797.9$ & 73 & 3,124 & 249 \\
\hline
\end{tabular}


the west side of San Francisco, water years 1987-88

because these are real numbers in the Fortran program but displayed as integers for clarity. The totals are calculated

\begin{tabular}{|c|c|c|c|c|c|c|c|c|c|c|c|c|}
\hline \multicolumn{4}{|c|}{ Municipal water } & \multicolumn{4}{|c|}{ Sewer budget } & \multicolumn{5}{|c|}{ Ground-water recharge } \\
\hline Outdoor & Indoor & Leaks & Net & Runoff & $\begin{array}{l}\text { Waste } \\
\text { water }\end{array}$ & Leaks & Net & $\begin{array}{l}\text { Impervious } \\
\text { areas }\end{array}$ & $\begin{array}{l}\text { Irrigated } \\
\text { areas }\end{array}$ & $\begin{array}{l}\text { Nonirrigated } \\
\text { areas }\end{array}$ & Leaks & Total \\
\hline 296 & 29 & 14 & 338 & 2 & 29 & 1 & 29 & 31 & 665 & 60 & 15 & $\overline{771}$ \\
\hline 0 & 0 & 0 & 0 & 0 & 0 & 0 & 0 & 0 & 0 & 0 & 0 & 0 \\
\hline 58 & 68 & 5 & 132 & 13 & 67 & 3 & 77 & 3 & 49 & 3 & 8 & 63 \\
\hline 0 & 0 & 0 & 0 & 0 & 0 & 0 & 0 & 7 & 0 & 32 & 0 & 40 \\
\hline 52 & 2 & 2 & 56 & 0 & 2 & 0 & 2 & 1 & 50 & 4 & 2 & 57 \\
\hline 275 & 50 & 14 & 338 & 9 & 49 & 2 & 56 & 35 & 179 & 6 & 16 & 237 \\
\hline 16 & 26 & 2 & 44 & 6 & 26 & 1 & 31 & 2 & 10 & 0 & 3 & 15 \\
\hline 24 & 0 & 1 & 26 & 19 & 0 & 1 & 18 & 2 & 17 & 0 & 2 & 20 \\
\hline 7 & 1 & 0 & 8 & 1 & 1 & 0 & 2 & 0 & 5 & 0 & 0 & 6 \\
\hline 28 & 38 & 3 & 68 & 6 & 37 & 2 & 41 & 1 & 20 & 0 & 5 & 26 \\
\hline 22 & 43 & 3 & 69 & 14 & 43 & 2 & 54 & 3 & 15 & 0 & 5 & 24 \\
\hline 21 & 122 & 6 & 149 & 60 & 119 & 7 & 172 & 7 & 14 & 2 & 13 & 36 \\
\hline 0 & 0 & 0 & 0 & 0 & 0 & 0 & 0 & 5 & 0 & 39 & 0 & 44 \\
\hline 27 & 68 & 4 & 99 & 14 & 67 & 3 & 78 & 4 & 17 & 1 & 7 & 28 \\
\hline 70 & 0 & 3 & 73 & 49 & 0 & 2 & 47 & 5 & 44 & 0 & 5 & 54 \\
\hline 6 & 3 & 0 & 10 & 3 & 3 & 0 & 6 & 1 & 4 & 0 & 0 & 5 \\
\hline 13 & 0 & 1 & 14 & 29 & 0 & 1 & 28 & 3 & 9 & 0 & 2 & 14 \\
\hline 25 & 26 & 2 & 54 & 8 & 26 & 1 & 32 & 2 & 16 & 0 & 3 & 21 \\
\hline 106 & 266 & 15 & 387 & 121 & 260 & 15 & 366 & 13 & 75 & 2 & 30 & 121 \\
\hline 201 & 73 & 11 & 286 & 161 & 72 & 9 & 223 & 27 & 121 & 0 & 20 & 168 \\
\hline 11 & 30 & 2 & 44 & 6 & 30 & 1 & 34 & 2 & 6 & 0 & 3 & 11 \\
\hline 26 & 1 & 1 & 28 & 2 & 1 & 0 & 2 & 2 & 17 & 6 & 1 & 26 \\
\hline 133 & 552 & 29 & 714 & 257 & 541 & 32 & 766 & 26 & 80 & 0 & 61 & 167 \\
\hline 0 & 0 & 0 & 0 & 14 & 0 & 1 & 13 & 3 & 101 & 0 & 1 & 105 \\
\hline 0 & 0 & 0 & 0 & 12 & 0 & 0 & 12 & 4 & 79 & 0 & 0 & 83 \\
\hline 0 & 0 & 0 & 0 & 13 & 0 & 1 & 12 & 4 & 82 & 0 & 1 & 86 \\
\hline 14 & 0 & 1 & 15 & 2 & 0 & 0 & 2 & 0 & 8 & 0 & 1 & 9 \\
\hline 300 & 1,858 & 90 & 2,248 & 678 & 1,821 & 100 & 2,399 & 75 & 187 & 4 & 190 & 457 \\
\hline 328 & 3,040 & 140 & 3,508 & 1,083 & 2,979 & 162 & 3,900 & 120 & 214 & 18 & 302 & 655 \\
\hline 448 & 10,744 & 466 & 11,659 & 1,547 & 10,530 & 483 & 11,593 & 172 & 303 & 31 & 949 & 1,455 \\
\hline 373 & 3,117 & 145 & 3,636 & 1,136 & 3,055 & 168 & 4,023 & 274 & 217 & 0 & 313 & 804 \\
\hline 61 & 76 & 6 & 143 & 17 & 75 & 4 & 88 & 39 & 202 & 40 & 10 & 291 \\
\hline 170 & 1,276 & 60 & 1,506 & 90 & 1,250 & 54 & 1,287 & 20 & 95 & 0 & 114 & 229 \\
\hline 3,112 & 21,512 & 1,026 & 25,650 & 5,371 & 21,082 & 1,058 & 25,395 & 896 & 2,898 & 249 & 2,082 & 6,127 \\
\hline
\end{tabular}


Table 21. Average annual output from the calibrated hydrologic routing model by land-use zone for

[Area in acres, all other values in acre-feet. For location of land-use zone, see fig. 8. Not all values add up to totals within the Fortran program and are a more accurate number than the sum of the integer values]

\begin{tabular}{|c|c|c|c|c|c|c|c|c|c|c|c|c|c|c|c|}
\hline \multirow[b]{3}{*}{$\begin{array}{l}\text { Land- } \\
\text { use } \\
\text { zone }\end{array}$} & \multirow[b]{3}{*}{ Rain } & \multicolumn{14}{|c|}{ Irrigated soil } \\
\hline & & \multicolumn{4}{|c|}{ Impervious } & \multirow[b]{2}{*}{ Area } & \multirow[b]{2}{*}{ Runoff } & \multirow[b]{2}{*}{$\begin{array}{l}\text { Evapo- } \\
\text { trans- } \\
\text { piration }\end{array}$} & \multicolumn{2}{|c|}{ Irrigation } & \multirow[b]{2}{*}{$\begin{array}{l}\text { Ground- } \\
\text { water } \\
\text { recharge }\end{array}$} & \multicolumn{4}{|c|}{ Nonirrigated soil } \\
\hline & & Area & $\begin{array}{l}\text { Depres- } \\
\text { sion } \\
\text { storage }\end{array}$ & $\begin{array}{c}\text { Runoff } \\
\text { to } \\
\text { sewer }\end{array}$ & $\begin{array}{l}\text { Ground- } \\
\text { water } \\
\text { recharge }\end{array}$ & & & & $\begin{array}{l}\text { Muni- } \\
\text { cipal } \\
\text { water }\end{array}$ & $\begin{array}{l}\text { Ground } \\
\text { water }\end{array}$ & & Area & Runoff & $\begin{array}{l}\text { Evapo- } \\
\text { trans- } \\
\text { piration }\end{array}$ & $\begin{array}{l}\text { Ground- } \\
\text { water } \\
\text { recharge }\end{array}$ \\
\hline 7 & 1,170 & 343.3 & 43 & 257 & 110 & 245.3 & 0 & 426 & 426 & 0 & 290 & 392.4 & 0 & 422 & 55 \\
\hline 13 & 464 & 311.2 & 39 & 299 & 33 & 19.4 & 0 & 36 & 35 & 0 & 22 & 58.4 & 0 & 65 & 7 \\
\hline 14 & 17 & .4 & 0 & 0 & 0 & 13.6 & 0 & 25 & 24 & 0 & 15 & 0 & 0 & 0 & 0 \\
\hline 15 & 20 & 11 & 1 & 9 & 2 & 5.9 & 1 & 11 & 11 & 0 & 6 & 0 & 0 & 0 & 0 \\
\hline 16 & 17 & .6 & 0 & 0 & 0 & 13.4 & 0 & 25 & 24 & 0 & 15 & 0 & 0 & 0 & 0 \\
\hline 17 & 17 & 1.4 & 0 & 1 & 1 & 12.6 & 0 & 23 & 22 & 0 & 14 & 0 & 0 & 0 & 0 \\
\hline 18 & 17 & 2.5 & 0 & 1 & 2 & 11.5 & 2 & 21 & 21 & 0 & 11 & 0 & 0 & 0 & 0 \\
\hline 20 & 140 & 81.9 & 10 & 79 & 9 & 23.4 & 0 & 43 & 42 & 0 & 26 & 11.7 & 0 & 13 & 1 \\
\hline 21 & 23 & 8 & 1 & 7 & 1 & 11.6 & 0 & 22 & 21 & 0 & 12 & .4 & 0 & 0 & 0 \\
\hline 22 & 41 & 10.8 & 1 & 8 & 3 & 25.2 & 0 & 47 & 45 & 0 & 27 & 0 & 0 & 0 & 0 \\
\hline 23 & 76 & 14.7 & 2 & 11 & 5 & 32.2 & 0 & 60 & 58 & 0 & 34 & 20.1 & 0 & 22 & 2 \\
\hline 24 & 17 & 7.5 & 1 & 5 & 2 & 6.7 & 0 & 13 & 12 & 0 & 7 & .8 & 0 & 1 & 0 \\
\hline 25 & 959 & 675.4 & 84 & 650 & 72 & 56.3 & 8 & 103 & 102 & 0 & 56 & 72.4 & 10 & 70 & 0 \\
\hline 34 & 62 & 1.6 & 0 & 0 & 2 & 0 & 0 & 0 & 0 & 0 & 0 & 50.4 & 0 & 56 & 0 \\
\hline 35 & 49 & .8 & 0 & 0 & 0 & 8.2 & 0 & 15 & 15 & 0 & 9 & 32 & 0 & 35 & 3 \\
\hline 36 & 18 & 1 & 0 & 1 & 1 & .4 & 0 & 1 & 1 & 0 & 1 & 13.5 & 0 & 15 & 1 \\
\hline 37 & 1,188 & 697.2 & 86 & 671 & 75 & 199.2 & 28 & 364 & 359 & 0 & 197 & 99.6 & 14 & 100 & 0 \\
\hline 38 & 27 & 5.8 & 1 & 5 & 1 & 16.1 & 2 & 30 & 29 & 0 & 16 & 1.2 & 0 & 1 & 0 \\
\hline 41 & 367 & 289.8 & 36 & 266 & 30 & 12.9 & 1 & 24 & 23 & 0 & 13 & 19.3 & 2 & 19 & 0 \\
\hline 42 & 6 & .2 & 0 & 0 & 0 & 4.5 & 0 & 8 & 8 & 0 & 4 & .3 & 0 & 0 & 0 \\
\hline 43 & 5 & .2 & 0 & 0 & 0 & 4.5 & 0 & 8 & 8 & 0 & 4 & .3 & 0 & 0 & 0 \\
\hline 44 & 11 & 1.5 & 0 & 1 & 1 & 6 & 0 & 11 & 11 & 0 & 6 & 2.5 & 0 & 2 & 0 \\
\hline 46 & 13 & .5 & 0 & 1 & 0 & 6 & 1 & 11 & 11 & 0 & 6 & 4.4 & 1 & 4 & 0 \\
\hline 47 & 10 & .4 & 0 & 0 & 0 & 2 & 0 & 4 & 4 & 0 & 2 & 5.6 & 1 & 6 & 0 \\
\hline 48 & 32 & .3 & 0 & 0 & 0 & 0 & 0 & 0 & 0 & 0 & 0 & 27.7 & 0 & 30 & 2 \\
\hline 49 & 171 & 127.5 & 16 & 117 & 13 & 7.5 & 1 & 14 & 14 & 0 & 7 & 15 & 2 & 15 & 0 \\
\hline 55 & 167 & 21.9 & 3 & 16 & 7 & 43.8 & 5 & 76 & 71 & 0 & 39 & 80.3 & 9 & 75 & 0 \\
\hline 56 & 25 & 15.4 & 2 & 13 & 3 & 3.3 & 0 & 6 & 5 & 0 & 3 & 3.3 & 0 & 3 & 0 \\
\hline 57 & 41 & 27 & 3 & 22 & 5 & 1.8 & 0 & 3 & 3 & 0 & 2 & 7.2 & 1 & 7 & 0 \\
\hline 58 & 6 & .2 & 0 & 0 & 0 & 4.8 & 1 & 9 & 9 & 0 & 5 & .1 & 0 & 0 & 0 \\
\hline 59 & 383 & 16.8 & 2 & 3 & 14 & 33.6 & 4 & 62 & 61 & 0 & 32 & 285.6 & 32 & 269 & 0 \\
\hline 60 & 24 & 14.1 & 2 & 13 & 1 & 5.9 & 1 & 11 & 11 & 0 & 6 & 1.1 & 0 & 1 & 0 \\
\hline 61 & 8 & 2.3 & 0 & 2 & 0 & 4.2 & 0 & 8 & 8 & 0 & 4 & .5 & 0 & 0 & 0 \\
\hline 62 & 102 & 87.4 & 11 & 0 & 85 & 4.7 & 0 & 9 & 9 & 0 & 4 & 1.9 & 0 & 2 & 0 \\
\hline 115 & 860 & 608.3 & 74 & 530 & 59 & 102.7 & 8 & 188 & 188 & 0 & 99 & 79 & 7 & 73 & 0 \\
\hline 116 & 3,132 & $2,113.6$ & 260 & 1,937 & 215 & 356.8 & 39 & 653 & 649 & 0 & 348 & 274.5 & 30 & 259 & 0 \\
\hline 117 & 2,629 & $1,697.1$ & 210 & 1,633 & 181 & 286.5 & 40 & 523 & 517 & 0 & 283 & 220.4 & 30 & 213 & 0 \\
\hline 119 & 297 & 210.2 & 26 & 142 & 61 & 49.1 & 4 & 90 & 90 & 0 & 47 & 13.7 & 1 & 13 & 0 \\
\hline 122 & 1,781 & $1,482.9$ & 182 & 1,495 & 15 & 31.2 & 3 & 57 & 57 & 0 & 30 & 46.8 & 5 & 44 & 0 \\
\hline 123 & 550 & 409.7 & 50 & 396 & 21 & 24.1 & 3 & 44 & 44 & 0 & 24 & 48.2 & 5 & 45 & 0 \\
\hline 124 & 3,656 & $2,751.2$ & 334 & 2,332 & 259 & 0 & 0 & 0 & 0 & 0 & 0 & 687.8 & 0 & 640 & 113 \\
\hline 125 & 378 & 259.2 & 32 & 257 & 14 & 32.4 & 4 & 59 & 59 & 0 & 32 & 32.4 & 4 & 31 & 0 \\
\hline 127 & 45 & 27.7 & 3 & 27 & 3 & 5.7 & 0 & 10 & 10 & 0 & 6 & 4.6 & 0 & 5 & 1 \\
\hline 128 & 37 & 1.5 & 0 & 1 & 0 & 27 & 0 & 47 & 0 & 45 & 31 & 1.5 & 0 & 2 & 0 \\
\hline 129 & 544 & 343.4 & 43 & 338 & 38 & 58 & 0 & 100 & 95 & 0 & 69 & 44.6 & 0 & 52 & 3 \\
\hline 130 & 364 & 91.5 & 11 & 78 & 20 & 30.5 & 4 & 56 & 55 & 0 & 30 & 183 & 25 & 177 & 0 \\
\hline 132 & 267 & 123.2 & 15 & 105 & 26 & 67.2 & 9 & 116 & 107 & 0 & 64 & 33.6 & 5 & 32 & 0 \\
\hline 133 & 75 & 2 & 0 & 1 & 1 & 44.2 & 5 & 82 & 80 & 0 & 43 & 19.8 & 2 & 19 & 0 \\
\hline 134 & 48 & 6.3 & 1 & 4 & 3 & 29.4 & 3 & 55 & 53 & 0 & 28 & 6.3 & 1 & 6 & 0 \\
\hline 135 & 269 & 12.6 & 2 & 0 & 12 & 2.5 & 0 & 5 & 5 & 0 & 3 & 237.8 & 0 & 206 & 52 \\
\hline Total & 20,624 & $2,921.3$ & 1,587 & 11,732 & 1,406 & 1,994 & 179 & 3,612 & 3,510 & 45 & 2,033 & $3,141.6$ & 187 & 3,049 & 240 \\
\hline
\end{tabular}


the east side of San Francisco, water years 1987-88

because these are real numbers in the Fortran program but displayed as integers for clarity. The totals are calculated

\begin{tabular}{|c|c|c|c|c|c|c|c|c|c|c|c|c|}
\hline \multicolumn{4}{|c|}{ Municipal water } & \multicolumn{4}{|c|}{ Sewer budget } & \multicolumn{4}{|c|}{ Ground-water recharge } & \multirow[b]{2}{*}{ Total } \\
\hline Outdoor & Indoor & Leaks & Net & Runoff & $\begin{array}{l}\text { Waste } \\
\text { water }\end{array}$ & Leaks & Net & $\begin{array}{l}\text { Impervious } \\
\text { areas }\end{array}$ & $\begin{array}{l}\text { Irrigated } \\
\text { areas }\end{array}$ & $\begin{array}{l}\text { Nonirrigated } \\
\text { areas }\end{array}$ & Leaks & \\
\hline 426 & 427 & 36 & 888 & 257 & 418 & 27 & 648 & 110 & 290 & 55 & 63 & $\overline{517}$ \\
\hline 35 & 1,804 & 77 & 1,916 & 299 & 1,768 & 83 & 1,985 & 33 & 22 & 7 & 160 & 221 \\
\hline 24 & 2 & 1 & 27 & 0 & 2 & 0 & 2 & 0 & 15 & 0 & 1 & 16 \\
\hline 11 & 25 & 1 & 37 & 10 & 24 & 1 & 33 & 2 & 6 & 0 & 2 & 11 \\
\hline 24 & 2 & 1 & 27 & 0 & 2 & 0 & 2 & 0 & 15 & 0 & 1 & 16 \\
\hline 22 & 2 & 1 & 25 & 1 & 2 & 0 & 2 & 1 & 14 & 0 & 1 & 16 \\
\hline 21 & 2 & 1 & 24 & 3 & 2 & 0 & 4 & 2 & 11 & 0 & 1 & 14 \\
\hline 42 & 170 & 9 & 221 & 79 & 166 & 10 & 235 & 9 & 26 & 1 & 19 & 55 \\
\hline 21 & 3 & 1 & 25 & 7 & 3 & 0 & 10 & 1 & 12 & 0 & 1 & 15 \\
\hline 45 & 1 & 2 & 48 & 8 & 1 & 0 & 8 & 3 & 27 & 0 & 2 & 32 \\
\hline 58 & 19 & 3 & 80 & 11 & 19 & 1 & 28 & 5 & 34 & 2 & 4 & 45 \\
\hline 12 & 9 & 1 & 22 & 5 & 9 & 1 & 13 & 2 & 7 & 0 & 2 & 11 \\
\hline 102 & 4,662 & 198 & 4,962 & 667 & 4,568 & 209 & 5,026 & 72 & 56 & 0 & 407 & 536 \\
\hline 0 & 0 & 0 & 0 & 0 & 0 & 0 & 0 & 2 & 0 & 0 & 0 & 2 \\
\hline 15 & 0 & 1 & 15 & 0 & 0 & 0 & 0 & 0 & 9 & 3 & 1 & 13 \\
\hline 1 & 1 & 0 & 2 & 1 & 1 & 0 & 2 & 1 & 1 & 1 & 0 & 2 \\
\hline 359 & 3,754 & 171 & 4,284 & 712 & 3,679 & 176 & 4,215 & 75 & 197 & 0 & 347 & 619 \\
\hline 29 & 17 & 2 & 48 & 7 & 16 & 1 & 23 & 1 & 16 & 0 & 3 & 20 \\
\hline 23 & 1,494 & 63 & 1,580 & 269 & 1,464 & 69 & 1,663 & 30 & 13 & 0 & 132 & 175 \\
\hline 8 & 0 & 0 & 9 & 1 & 0 & 0 & 1 & 0 & 4 & 0 & 0 & 5 \\
\hline 8 & 0 & 0 & 9 & 1 & 0 & 0 & 1 & 0 & 4 & 0 & 0 & 5 \\
\hline 11 & 0 & 0 & 12 & 1 & 0 & 0 & 2 & 1 & 6 & 0 & 0 & 7 \\
\hline 11 & 0 & 0 & 11 & 2 & 0 & 0 & 2 & 0 & 6 & 0 & 0 & 7 \\
\hline 4 & 0 & 0 & 4 & 1 & 0 & 0 & 1 & 0 & 2 & 0 & 0 & 2 \\
\hline 0 & 0 & 0 & 0 & 0 & 0 & 0 & 0 & 0 & 0 & 2 & 0 & 3 \\
\hline 14 & 565 & 24 & 603 & 119 & 554 & 27 & 646 & 13 & 7 & 0 & 51 & 71 \\
\hline 71 & 106 & 7 & 185 & 29 & 104 & 5 & 128 & 7 & 39 & 0 & 12 & 59 \\
\hline 5 & 32 & 2 & 39 & 13 & 31 & 2 & 43 & 3 & 3 & 0 & 4 & 9 \\
\hline 3 & 0 & 0 & 3 & 23 & 0 & 1 & 22 & 5 & 2 & 0 & 1 & 8 \\
\hline 9 & 7 & 1 & 17 & 1 & 7 & 0 & 7 & 0 & 5 & 0 & 1 & 6 \\
\hline 61 & 24 & 4 & 89 & 39 & 24 & 3 & 60 & 14 & 32 & 0 & 7 & 52 \\
\hline 11 & 30 & 2 & 43 & 14 & 30 & 2 & 42 & 1 & 6 & 0 & 4 & 11 \\
\hline 8 & 10 & 1 & 19 & 2 & 10 & 0 & 12 & 0 & 4 & 0 & 1 & 6 \\
\hline 9 & 14 & 1 & 23 & 1 & 13 & 1 & 13 & 85 & 4 & 0 & 2 & 91 \\
\hline 188 & 1,718 & 79 & 1,985 & 545 & 1,683 & 89 & 2,139 & 59 & 99 & 0 & 168 & 326 \\
\hline 649 & 3,979 & 193 & 4,821 & 2,006 & 3,899 & 236 & 5,669 & 215 & 348 & 0 & 429 & 993 \\
\hline 517 & 9,584 & 421 & 10,522 & 1,703 & 9,393 & 444 & 10,651 & 181 & 283 & 0 & 865 & 1,329 \\
\hline 90 & 396 & 20 & 506 & 148 & 388 & 21 & 514 & 61 & 47 & 0 & 41 & 150 \\
\hline 57 & 33,940 & 1,417 & 35,414 & 1,503 & 33,262 & 1,391 & 33,374 & 15 & 30 & 0 & 2,808 & 2,853 \\
\hline 44 & 2,515 & 107 & 2,666 & 404 & 2,465 & 115 & 2,754 & 21 & 24 & 0 & 222 & 266 \\
\hline 0 & 4,985 & 208 & 5,193 & 2,332 & 4,885 & 289 & 6,929 & 259 & 0 & 113 & 497 & 868 \\
\hline 59 & 1,691 & 73 & 1,822 & 265 & 1,657 & 77 & 1,845 & 14 & 32 & 0 & 150 & 195 \\
\hline 10 & 55 & 3 & 67 & 27 & 54 & 3 & 77 & 3 & 6 & 1 & 6 & 16 \\
\hline 0 & 0 & 0 & 0 & 1 & 0 & 0 & 1 & 0 & 31 & 0 & 0 & 31 \\
\hline 95 & 2,263 & 98 & 2,456 & 338 & 2,217 & 102 & 2,453 & 38 & 69 & 3 & 200 & 310 \\
\hline 55 & 221 & 12 & 288 & 108 & 217 & 13 & 311 & 20 & 30 & 0 & 25 & 74 \\
\hline 107 & 325 & 18 & 450 & 119 & 318 & 17 & 420 & 26 & 64 & 0 & 35 & 126 \\
\hline 80 & 1 & 3 & 84 & 8 & 1 & 0 & 8 & 1 & 43 & 0 & 3 & 48 \\
\hline 53 & 1 & 2 & 57 & 8 & 1 & 0 & 9 & 3 & 28 & 0 & 2 & 34 \\
\hline 5 & 0 & 0 & 5 & 0 & 0 & 0 & 0 & 12 & 3 & 52 & 0 & 67 \\
\hline 3,510 & 74,855 & 3,265 & 81,630 & 12,098 & 73,358 & 3,418 & 82,038 & 1,406 & 2,033 & 240 & 6,681 & 10,362 \\
\hline
\end{tabular}

Table 2163

(PAge 65 Followis) 
Appendix 1. Description of variables used in hydrologic routing model

[acre-ft, acre-foot; ${ }^{\circ} \mathrm{F}$, degree Fahrenheit; in., inch; in/mo, inch per month]

\begin{tabular}{lll}
\hline Variable name & \multicolumn{1}{c}{ Description } & Units \\
\hline & & \multicolumn{1}{c}{ Global variables } \\
AVGRAIN & Average annual rainfall at the three NOAA stations (measured) & in. \\
AVGTEMP & Average monthly temperature at San Francisco Airport (measured) & ${ }^{\circ} \mathrm{F}$ \\
DEPR & Depression storage (estimated) & in/mo \\
DYLFR & Fraction of annual daylight hours in each month (measured) & -- \\
EFFIC & Irrigation efficiency as fraction of irrigation water (estimated) & -- \\
ETFIRR & Ratio of actual to potential evapotranspiration at which & \\
& irrigation is initiated (estimated) & -- \\
ETMULT & Calibration parameter for adjusting reference evapotranspiration & -- \\
FRACIND & Monthly indoor water use as a fraction of monthly total use (estimated) & -- \\
RAIN & Monthly rainfall at the three NOAA stations & in. \\
SLKRATE & Sewer-pipe leakage rate as fraction of flow (estimated) & -- \\
SLOPE & Slope of linear relation for estimating runoff from pervious areas & -- \\
TLINDOOR & Total monthly indoor water use (calculated) & acre-ft \\
TLMUNI & Total monthly municipal water use (measured) & acre-ft \\
WLKRATE & Water-pipe leakage rate as fraction of flow (measured) & -- \\
WWFRAC & Fraction of indoor water use that becomes wastewater (estimated) & -- \\
& & \\
\end{tabular}

Zone-dependent variables

$\begin{array}{lll}\text { AETIRR } & \text { Actual evapotranspiration for irrigated areas (calculated) } & \text { in. } \\ \text { AREAIMP } & \text { Impervious area (measured and extrapolated) } \\ \text { AREAIRR } & \text { Irrigated area (measured and extrapolated) } & \text { acre } \\ \text { AREANON } & \text { Nonirrigated pervious area (calculated) } & \text { acre } \\ \text { AREATL } & \text { Total area (measured) } & \text { acre } \\ \text { AWC } & \text { Maximum available water content (estimated) } & \text { in } \\ \text { AWCMXI } & \text { Maximum available water capacity of irrigated soil (calculated) } & \text { in. } \\ \text { AWCMXN } & \text { Maximum available water capacity of nonirrigated soil (calculated) } & \text { in. } \\ \text { AWMUNI } & \text { Municipal water used for irrigation (calculated) } & \text { in. } \\ \text { ETADJ } & \text { Average temperature difference between zone location and regional } & \\ & \text { temperature station (estimated) } & \text { oF } \\ \text { ET } & \text { Reference evapotranspiration (calculated) } & \text { in. } \\ \text { FACKI } & \text { Monthly crop coefficient }\left(K_{c}\right) \text { reflecting the growth stage of } & -- \\ & \text { vegetation in irrigated areas (estimated) } & - \\ \text { FACKN } & \text { Monthly crop coefficient }\left(K_{c}\right) \text { reflecting the growth stage of } & - \\ \text { FRACGW } & \text { vegetation in nonirrigated areas (estimated) } & - \\ \text { FRIMPLK } & \text { Fraction of irrigation supplied by ground water (estimated) } & - \\ & \text { Fraction of impervious area that allows leakage or runoff to } & \text { in. } \\ \text { GWPUMP } & \text { pervious areas (estimated) } & - \\ \text { ICURVE } & \text { Ground water pumped for irrigation purposes (calculated) }\end{array}$

Footnote at end of table. 


\begin{tabular}{|c|c|c|}
\hline Variable name & Description & Units \\
\hline \multicolumn{3}{|c|}{ Zone-dependent variables--Continued } \\
\hline PET & Potential evapotranspiration (calculated) & in. \\
\hline RAINIRR & Net rainfall on irrigated areas (calculated) & in. \\
\hline RAINNON & Net rainfall on nonirrigated areas (calculated) & in. \\
\hline RANNL & Average annual rainfall (estimated from precipitation map) & in. \\
\hline RCHIMP & Recharge from leakage through impervious areas (calculated) & acre-ft \\
\hline RCHIRR & Recharge from irrigated areas (calculated) & in. \\
\hline RCHNON & Recharge from nonirrigated areas (calculated) & in. \\
\hline RECH & Total recharge (calculated) & acre-ft \\
\hline ROFFIMP & Runoff from impervious areas (calculated) & acre-ft \\
\hline ROFFIRR & Runoff from irrigated areas (calculated) & in. \\
\hline ROFFNON & Runoff from nonirrigated areas (calculated) & in. \\
\hline RTDPTHI & Plant root depth in irrigated areas (estimated) & in. \\
\hline RTDPTHN & Plant root depth in nonirrigated areas (estimated) & in. \\
\hline SEWERQ & Sewer flow (calculated) & acre-ft \\
\hline SLEAK & Leakage from sewer pipes (calculated) & acre-ft \\
\hline SMIRR & Soil moisture in irrigated areas (calculated) & in. \\
\hline SMIRR0 & Initial soil moisture for irrigated areas (estimated) & $\left({ }^{1}\right)$ \\
\hline SMNON & Soil moisture in nonirrigated areas (calculated) & in. \\
\hline SMNONO & Initial soil moisture for nonirrigated areas (estimated) & $\left({ }^{1}\right)$ \\
\hline YINTCP & $\begin{array}{l}Y \text { intercept of linear relation for estimating runoff from pervious } \\
\text { areas }\end{array}$ & in. \\
\hline ZRAIN & $\begin{array}{l}\text { Calculated rainfall based on the precipitation map and measured } \\
\text { precipitation at the three NOAA stations (calculated) }\end{array}$ & in. \\
\hline ZINDOOR & Zonal indoor water use (calculated) & acre-ft \\
\hline ZMUNI & Total municipal water use (calculated) & acre-ft \\
\hline ZWEIGHTF & Fractional water-use intensity factor for indoor use (calculated) & -- \\
\hline ZWEIGHTR & $\begin{array}{l}\text { Relative water-use intensity factor for indoor use (estimated from } \\
\text { population density) }\end{array}$ & -- \\
\hline ZWLEAK & Leakage from water-delivery pipes (calculated) & acre-ft \\
\hline ZWW & Wastewater generated by indoor use (calculated) & acre-ft \\
\hline
\end{tabular}

\footnotetext{
${ }^{1}$ Inches of water per inch of soil depth
} 
Appendix 2. Equations used in hydrologic routing model

[0.083333 is the number of inches per foot. Equations 1-7 are in the text]

--Calculate rainfall for the zone:

$$
\text { ZRAIN }=\operatorname{RANNL} \times \frac{\left.\sum_{i=1}^{3}(\operatorname{RAIN})_{i} \times(\text { AVGRAIN })_{i}\right)}{3} .
$$

where $i=$ NOAA precipitation station.

--Calculate recharge and runoff for impervious areas:

$$
\begin{aligned}
\text { RCHIMP } & =(\text { AREAIMP } \times(\text { ZRAIN }- \text { DEPR })) \times \text { FRIMPLK } \times 0.083333 . \\
\text { ROFFIMP } & =((\text { AREAIMP } \times(\text { ZRAIN }- \text { DEPR })) \times 0.083333)-\text { RCHIMP. }
\end{aligned}
$$

--Calculate runoff and contribution to soil moisture from irrigation:

if ZRAIN $>$ YINTCP then ROFFIRR $=($ SLOPE $\times Z R A I N)-Y I N T C P$.

if ZRAIN $\leq$ YINTCP then ROFFIRR $=0$.

$$
\begin{aligned}
& \text { RAINIRR = ZRAIN - ROFFIRR. } \\
& \text { SMIRR = SMIRR0 + RAINIRR. }
\end{aligned}
$$

--Calculate reference evapotranspiration:

$$
\mathrm{ET}_{\mathrm{o}}=\mathrm{DYLFR} \times \mathrm{ETMULT} \times(0.0173(\mathrm{AVGTEMP}+\mathrm{ETADJ}-0.314)) \times(\mathrm{AVGTEMP}+\mathrm{ETADJ}) .
$$

--Calculate potential evapotranspiration:

$$
\mathrm{PET}=\mathrm{ET}_{0} \times \mathrm{FACKI}
$$

--Calculate the maximum available water capacity for irrigated and nonirrigated soils:

$$
\begin{aligned}
A W C M X I & =A W C \times R T D P T H I . \\
A W C M X N & =A W C \times R T D P T H N .
\end{aligned}
$$


--Calculate actual evapotranspiration for irrigated areas:

If $S M I R R \geq A W C M X I$ then AETIRR = PET

If $0<$ SMIRR $<A W C M X I$ then AETIRR is calculated from soil-moisture retention curves (see fig. 13)

--Calculate irrigation if soil moisture is depleted below a threshold, where the threshold is defined by the Xvalue of the appropriate soil-moisture retention curve (fig. 13) for AET/PET = ETFIRR

If SMIRR/AWCMXI<threshold then irrigation occurs

--Calculate relative amounts of irrigation water from ground water and municipal sources:

$$
\text { GWPUMP }=((\text { AWCMXI }- \text { SMIRR }) / \text { EFFIC }) \times \text { FRACGW } .
$$

$$
\text { AWMUNI }=((\text { AWCMXI }- \text { SMIRR }) / E F F I C)-\text { GWPUMP. }
$$

--Add irrigation water to soil moisture:

$$
\text { SMIRR }=\text { SMIRR }+\frac{\text { AWCMXI }- \text { SMIRR }}{\text { EFFIC }} .
$$

--If soil moisture is greater than that needed by plants, then excess soil moisture becomes recharge:

If SMIRR $>$ AWCMXI then RCHIRR = SMIRR - AWCMXI .

--Repeat evapotranspiration, soil moisture, and recharge calculations for nonirrigated areas (not shown, as equations are identical).

--Calculate total indoor water use and express the relative indoor water use intensity factor as a percentage:

TLINDOOR $=$ TLMUNI $\times$ FRACIND.

$$
\mathrm{ZWEIGHTF}=\frac{\text { ZWEIGHTR } \times \text { AREATL }}{\sum_{i=1}^{\text {number of zones }}\left(\text { AREATL }_{i} \times \mathrm{ZWEIGHTR}_{i}\right)}
$$

--Calculate zonal indoor water use, the wastewater fraction of indoor use, and total municipal use:

$$
\text { ZINDOOR }=(\text { ZWEIGHT } \times \text { TLINDOOR }) \times(1-\text { WLKRATE }) \text {. }
$$

$$
\mathrm{ZWW}=\mathrm{ZINDOOR} \times \mathrm{WWFRAC} .
$$




$$
\text { ZMUNI }=(\text { ZWEIGHT } \times \text { TLINDOOR })+\left(\frac{\text { AWMUNI } \times \text { AREAIRR } \times 0.083333}{1.0-\text { WLKRATE }}\right)
$$

--Calculate municipal water pipe leaks:

$$
\text { ZWLEAK = ZMUNI } \times \text { WLKRATE } .
$$

--Combine all inflows to sewer:

$$
\begin{array}{r}
\text { SEWERQ }=\text { ZWW }+ \text { ROFFIMP }+(\text { ROFFIRR } \times \text { AREAIRR } \times 0.083333) \\
+(\text { ROFFNON } \times \text { AREANON } \times 0.083333)
\end{array}
$$

--Calculate sewer leaks and subtract from sewer flow:

$$
\text { SLEAK = SEWERQ } \times \text { SLKRATE. }
$$

$$
\text { SEWERQ = SEWERQ }- \text { SLEAK } \text {. }
$$

--Combine all recharge items:

$$
\begin{aligned}
\mathrm{RECH}=\mathrm{ZWLEAK}+ & \text { SLEAK } \\
+ & \mathrm{RCHIMP}+(\mathrm{RCHIRR} \times \mathrm{AREAIRR} \times 0.083333) \\
& +(\mathrm{RCHNON} \times \mathrm{AREANON} \times 0.083333)
\end{aligned}
$$

--Do calculations for all zones, then increment time step and iterate. 